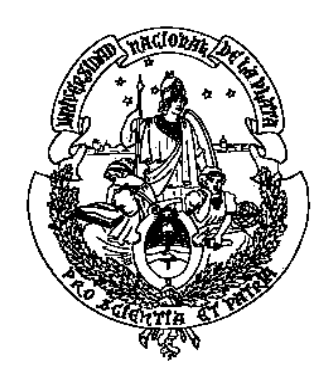

UNIVERSIDAD NACIONAL DE LA PLATA

FACULTAD DE CIENCIAS EXACTAS

DEPARTAMENTO DE CIENCIAS BIOLÓGICAS

Trabajo de Tesis Doctoral:

SEÑALES HIPERTRÓFICAS DISPARADAS POR

LA ANGIOTENSINA II EN EL MIOCARDIO: ROL

DEL RECEPTOR DEL FACTOR DE

CRECIMIENTO EPIDÉRMICO Y DE LAS

ESPECIES REACTIVAS DEL OXÍGENO.

Tesista: Lic. BREA, Maria Soledad

Director: Dr. PÉREZ, Néstor Gustavo

Codirector: Dr. MORGAN, Patricio Eduardo

Año: 2017 

El presente trabajo de tesis, para optar al grado de Doctor de la Facultad de Ciencias Exactas de la Universidad Nacional de La Plata, fue realizado en el Centro de Investigaciones Cardiovasculares (CIC) - Dr. Horacio E. Cingolani, de la Facultad de Ciencias Médicas, de la Universidad Nacional de La Plata, bajo la dirección del Dr. Néstor Gustavo Pérez y la codirección del Dr. Patricio Eduardo Morgan. 



\section{Mi reconocimiento}

A las autoridades actuales del CIC, el Dr. Martín Vila Petroff y el Dr. Alejandro Aiello, por permitirme realizar mi trabajo de investigación en el CIC. Y a las autoridades en el 2012, la Dra. Alicia Mattiazzi y el Dr. Martín Vila Petroff, por haberme abierto las puertas del instituto.

A la Universidad Nacional de La Plata (UNLP), por haberme otorgado la Beca Doctoral Tipo A, que me permitió iniciar el presente trabajo doctoral. Y al CONICET, por haberme otorgado la Beca de Finalización de Doctorado Tipo II para poder terminarlo.

A la Agencia Nacional de Promoción Científica y Tencológica (ANCyPT) y al CONICET, por los subsidios PICT y PIP otorgados para realizar los experimentos del trabajo.

A las autoridades de la Facultad de Ciencias Exactas, que me aceptaron en la Carrera de Doctorado en la misma Facultad que me formó como Licenciada en Biotecnología y Biología Molecular. 



\section{Agradecimientos}

Considerando que la tesis es un trabajo de casi 5 años, agradecer a todos los que lo hicieron posible, que son muchos, no es sencillo. Sobre todo porque hay para agradecer tanto grandes (grandísimas) acciones como pequeños (grandísimos) detalles. Además de hacer esta tesis hice algo parecido a vivir en estos 5 años, y coordinar ambas cosas llevó su prueba y error. Decirle a cada uno de los agradecidos todo lo que tengo para agradecerle es casi como para hacer otra tesis entera de agradecimientos (lo cual me llevaría en el final a escribir los agradecimientos de una tesis de agradecimientos, y ya se volvería un tanto confuso). Así que valiéndome de este contexto científico, vamos a dejar escritos los "short titles" de cada gracias, el resto será en persona.

El primer agradecimiento, sin duda, es para mis directores, Gustavo y Patricio. Tener la suerte de encontrarme con dos personas tan buenas como ustedes para iniciarme y dirigirme en este camino de la ciencia es algo que voy a agradecer toda la vida. Gracias a los dos por encontrar la distancia justa a la cual no estar ni muy lejos como para dejarme sola, ni muy cerca como para no dejarme crecer. Gracias por confiar en mí, por darme siempre la libertad de proponer, y por darme las herramientas para hacerlo. Gus, en aquel 2012, aún sin licenciatura, me aparecí en tu laboratorio (cosa que de paso le agradecemos a Fer) a pedirte hacer con vos una tesina. Tu respuesta fue "no sé ni lo que es una tesina, pero vamos", desde ese instante hasta hoy, gracias por absolutamente todo. Patri, desde ese primer clonado que iba a durar una semana y se extendió un poco más, gracias por enseñarme a cuestionarme todo, a pensar varias veces lo mismo, pero sobre todo gracias por hacer todo siempre con una sonrisa.

Una de las cosas que aprendí en estos años es a trabajar en grupo. Y este trabajo científico tiene un enorme grupo atrás. Gracias Clau, fuiste mi tercera directora encubierta, gracias por darme siempre tu tiempo, tu espacio, tu charla y tu consejo. Gracias Enrique por estar siempre dispuesto a formar parte de esto. Gracias Gi y Dai, no sólo por lo que aportaron con sus horas de experimento, sino también por el acompañamiento, por la ayuda y por los mates. Gracias Lean, Pini y Carito Ciancio, ustedes también son parte de este trabajo y por lo tanto de esta historia.

Gracias (muchas) a todo el Centro de Investigaciones Cardiovasculares. A todo, con todas sus transformaciones en estos 5 años. Trabajé en una gran familia, donde el altísimo nivel científico sólo se ve opacado por la calidad humana. Todos de alguna manera contribuyeron a esta tesis, ya no hablando de experimentos sino hablando de charlas de pasillo, de mates, de felicitaciones, de consejos. De acompañamiento. Dentro de esta familia, gracias en particular a mis amigas, que son lo que más le agradezco a la ciencia sin dudas. Santalla, que la vida misma se convierte en raíz casi que debería ponerlo como conclusión, gracias por todo. Barbi, la pose de poder es un resumen digno de todo lo que tengo que agradecerte, pero sobre todo los últimos meses de este camino. Jaquenod, una de las mejores incorporaciones que hizo mi doctorado. Gabita, sin duda lo que más extrañé en los últimos meses de laboratorio. Sofi, gracias por la paciencia a mis malos humores. Salas, mi buen amigo, esta campaña volveremos a estar contigo.

A mi segundo laboratorio, el INIBIOLP, le debo no sólo el préstamo de equipos e ideas, sino también personas hermosas que se doctoran conmigo. Marian, gracias a Dios que existen tus abrazos. Belu, la primera sección de esta tesis es casi 50\% tuya. Eli, tus manos mágicas en la cocina 
supieron darle a mi cerebro la energía necesaria. Carli, las dos sabemos que sin tu conocimiento de trámites esto no hubiera sido posible.

A los locos hermosos que me dejó la facultad, casi 10 años después de conocernos se doctoran conmigo. Marita, Meli y Fla, son sencillamente todo lo que está bien, gracias por acompañarme siempre, por sufrir los experimentos fallidos y disfrutar los logros conmigo. Las espero del otro lado de la meta. Tomi, desde el lejano sitio donde elegiste residir, gracias por esos increíbles mails que siempre me hacen llorar de la risa.

Hay un grupo enorme de personas hermosas, que la vida me fue poniendo en el camino, que aprendieron de biología molecular e hipertrofia cardíaca conmigo, que se bancaron humores que ni siquiera entendían porque jamás tuvieron que pasar $48 \mathrm{hs}$ haciendo un Western blot para que no de absolutamente nada, y que fueron ese apoyo tan necesario afuera de la locura científica. Mica, vos sí que te doctorás conmigo, gracias por todos los abrazos que me levantaron de cada caída. Andre, gracias eternas por esos audios que me hacen empezar el día con una sonrisa enorme, gracias por acompañarme siempre desde el otro lado del mar. Cami, con nuestras intermitencias son años de acompañarnos, y eso se agradece siempre. Zurdi y Emmita, gracias por la locura, siempre gracias por eso. Flor, gracias por esos abrazos que varias veces estuvieron al borde de dejarme sin costillas. Yaz, otra campeona que siempre se hizo presente desde el otro continente, gracias por el aguante en diferido. Juancito, ese profe de guitarra que supo darme desde un instrumento la calma que nada más me pudo dar. Flor, nunca pensé que algo tan feo como el inglés fuera a darme algo tan lindo como vos.

Por último, gracias totales a mi familia. Son el motor y la base de todo, cuando uno tiene en casa valores tan altos, todo en la vida se hace más fácil. Apenas aprendieron a reproducir el título de mi carrera de grado, todavía me preguntan en qué trabajo, pero se doctoran conmigo (para preguntarme después de qué se doctoraron, obvio). A mis abuelos, Cuca, Mario y Rosa, que son el mejor ejemplo de que la vida vivida con amor y trabajo es hermosa. A mis tíos, Sari, Alicia, Marta y Marito, que siempre están disponibles y dispuestos para todo. A mis hermanos, Fran, Vicky y Lola, que son sin duda alguna lo mejor que tiene este mundo, pese a que el $90 \%$ del tiempo tratemos de hacernos creer mutuamente lo contrario. Y a mi mamá, la persona más fuerte que conozco, gracias por enseñarme desde el ejemplo a levantarme de todo. 
A mi papá.

Por todo lo que él quiso que yo sea.

Y por todo lo que él supo que yo iba a ser. 



\section{ÍNDICE}

\section{INTRODUCCIÓN}

1. RECEPTOR DEL FACTOR DE CRECIMIENTO EPIDÉRMICO (EGFR) (Pág. 2 a 7)

1.1. Generalidades

pág. 2

1.2. Estructura de los receptores ErbB

pág. 2

1.3. Activación del EGFR

pág. 4

1.4. Trans-activación del EGFR

pág. 5

1.5. Ligandos extracelulares de los receptores ErbB

pág. 6

1.6. Receptores ErbB y sus ligandos en el corazón pág. 6

2. RUTAS DE SEÑALIZACIÓN DISPARADAS POR EL ESTIRAMIENTO CARDÍACO (Pág. 7 a 9)

\section{HIPERTROFIA CARDÍACA (Pág. 9 a 13)}

3.1. Epidemiología

pág. 9

3.2. Hipertrofia cardíaca. Definición y clasificaciones

pág. 10

3.3. Participación del EGFR en la HCP

pág. 11

3.4. Estrés oxidativo en la hipertrofia

pág. 12

4. SILENCIAMIENTO GÉNICO MEDIANTE RNA DE INTERFERENCIA (Pág. 13 a 16)

4.1. Sistema de delivery: lentivirus

pág. 15

\section{HIPÓTESIS Y OBJETIVOS}

pág. 17

\section{MATERIALES Y MÉTODOS}

1. MODELOS EXPERIMENTALES (Pág. 19 a 20)

1.1. Línea celular HEK 293T

pág. 19

1.2. Rattus norvegicus

pág. 19

2. CLONADO DEL shRNA (Pág. 19 a 26)

2.1. Diseño del shRNA-EGFR

pág. 19

2.2. Generación del inserto de clonado

pág. 21

2.2.1. Reacción de "annealing"

pág. 21

2.2.2. Electroforesis en geles de agarosa

pág. 21

2.2.3. Digestión enzimática del inserto

pág. 21

2.2.4. Purificación del inserto digerido

pág. 21

2.2.5. Cuantificación del producto digerido

pág. 22

2.3. Generación del vector de clonado

pág. 22

2.3.1. Vector utilizado para el clonado

pág. 22

2.3.2. Digestión enzimática del vector

pág. 22

2.3.3. Purificación del vector digerido

pág. 22

2.3.4. Cuantificación del producto digerido

pág. 23 
2.4. Ligación del inserto al vector

pág. 23

2.5. Producción y purificación del vector de transferencia clonado

pág. 23

2.5.1. Bacterias E. coli DH5- $\alpha$

pág. 23

2.5.2. Transformación de bacterias electrocompetentes

pág. 23

2.5.3. Aislamiento del vector: Miniprep

pág. 24

2.5.4. Aislamiento del vector: Maxiprep

pág. 24

2.5.5. Precipitación fenol-cloroformo

pág. 24

pág. 25

2.6.1. Reacción de PCR y digestión del amplicón

pág. 25

2.6.2. Digestión enzimática del plásmido recombinante

pág. 26

2.6.3. Secuenciación

pág. 26

\section{PRODUCCIÓN DE LENTIVIRUS (Pág. 26 a 27)}

3.1. Producción de lentivirus por transfección de HEK 293T

3.2. Concentración del lentivirus obtenido

pág. 26

pág. 27

3.3. Titulación del virus

pág. 27

4. EXPERIMENTOS DE SILENCIAMIENTO in vitro (Pág. 27 a 28)

4.1. Expresión del EGFR de rata en células HEK $293 \mathrm{~T}$

pág. 27

4.2. Curvas de silenciamiento

pág. 28

5. EXPERIMENTOS DE SILENCIAMIENTO in vivo (Pág. 28 a 33)

5.1. Infusión de Ang II para generar HC

pág. 28

5.2. Inyección intramiocárdica del lentivirus

pág. 28

5.3. Ecocardiografía

pág. 29

5.4. Determinación de la presión arterial

pág. 30

5.5. Determinación de área de miocitos y colágeno

pág. 30

5.6. Estudios de funcionalidad en papilares aislados

pág. 30

5.6.1. Aislamiento de músculos papilares y determinación de fuerza contráctil

pág. 30

5.6.2. Determinación de $\mathrm{pH}$ intracelular $(\mathrm{pHi})$

pág. 31

5.6.3. Determinación de la actividad del NHE1 por pulso

de amonio

pág. 31

5.6.4. Determinación de la rigidez miocárdica

pág. 31

pág. 32

5.7.1. Medición de la producción de anión superóxido $\left(\mathrm{O}_{2}{ }^{*}\right)$

pág. 32

5.7.2. Peroxidación lipídica

pág. 32

5.7.3. Actividad de NADPH oxidasa (NOX)

pág. 32

pág. 32

5.8. Western blot

pág. 33

5.9. Microscopía confocal

pág. 33

5.10. Estadística 


\section{RESULTADOS}

SECCIÓN I: CLONADO MOLECULAR Y SILENCIAMIENTO in vitro (Pág. 35 a 42)

1. Clonado del shRNA

pág. 35

2. Producción de lentivirus

pág. 39

3. Experimentos de silenciamiento in vitro

pág. 40

$\checkmark$ Expresión del EGFR de rata en células HEK 293T

pág. 40

$\checkmark$ Curvas de silenciamiento

pág. 42

SECCIÓN II: ROL DEL EGFR EN LA SEGUNDA FASE DE FUERZA (SFF) (Pág. 42 a 52)

1. Silenciamiento específico del EGFR in vivo

pág. 43

2. Parámetros morfométricos y ecocardiográficos

pág. 45

3. Desarrollo de SFF en ratas con 1-shSCR y l-shEGFR

pág. 45

4. Activación del NHE1 por Ang II y silenciamiento del EGFR

pág. 47

5. Evaluación del estrés oxidativo en ausencia del EGFR

pág. 48

6. Activación de quinasas redox-sensibles: ERK1/2 y p90RSK

pág. 50

SECCIÓN III: PARTICIPACIÓN DEL EGFR EN LA HIPERTROFIA CARDÍACA (Pág. 53 a 64)

1. Distribución del virus y silenciamiento del EGFR en ratas SHR

pág. 55

2. Evaluación de la hipertrofia cardíaca

3. Estudio de la presión arterial y evaluación de la función cardíaca por ecocardiografía

pág. 57

. Estudio de la fibrosis y rigidez miocárdica

pág. 57

5. Actividad del NHE1 en SHR con silenciamiento del EGFR

pág. 59

pág. 60

6. Efecto del silenciamiento del EGFR sobre el estrés oxidativo en SHR

pág. 61 



\section{LISTADO DE ABREVIATURAS}

Ald: aldosterona.

Ang II: angiotensina II.

AT1: receptor de angiotensina II tipo 1.

ECV: enfermedades cardiovasculares.

EGF: factor de crecimiento epidérmico.

EGFR: receptor del factor de crecimiento epidérmico.

ET-1: endotelina 1.

GPCR: receptores acoplados a proteína $G$

HB-EGF: factor de crecimiento tipo EGF unido a heparina.

HC: hipertrofia cardíaca.

HCF: hipertrofia cardíaca fisiológica.

HCP: hipertrofia cardíaca patológica.

HEK: células de riñón de embrión humano.

MR: receptor de mineralocorticoides.

NCX: intercambiador $\mathrm{Na}^{+} / \mathrm{Ca}^{+2}$

NHE1: intercambiador $\mathrm{Na}^{+} / \mathrm{H}^{+}$

NOX: NADPH oxidasa.
NRGs: neuregulinas.

PTK: fosfo tirosina-quinasa.

RISC: complejo de silenciamiento inducido por RNA.

RNAi: RNA de interferencia.

ROS: especies reactivas del oxígeno.

RTKs: receptores tirosina quinasa.

SCR: del inglés "scrambled", secuencia de nucleótidos desordenada.

SFF: segunda fase de fuerza.

SHR: ratas espeontáneamente hipertensas.

shRNA: RNA doble cadena con una pequeña horquilla.

siRNA: RNA de interferencia pequeño.

WKY: ratas Wistar-Kyoto. 

INTRODUCCIÓN 


\section{Receptor del factor de crecimiento epidérmico (EGFR).}

\subsection{Generalidades.}

Las células están continuamente expuestas a diversos estímulos, desde factores endócrinos y parácrinos solubles, hasta moléculas de señalización provenientes del entorno. Es de vital importancia que estas señales extracelulares sean interpretadas correctamente por la célula, a fin de ejecutar una respuesta apropiada de desarrollo, adaptación y proliferación. La familia de receptores de tirosina-quinasa (RTKs) tiene un rol fundamental en estos procesos. Mediante la unión a ligandos peptídicos específicos, son capaces de integrar esos estímulos externos con las vías internas de transducción de señales, contribuyendo de esa forma a la habilidad de la célula para responder correctamente a su entorno [1].

Las proteínas conocidas como ErbB pertenecen a la subclase I de la familia de RTKs, que a su vez consta de cuatro miembros, uno de los cuales, el receptor del factor de crecimiento epidérmico o EGFR (del inglés Epidermal Growth Factor Receptor, también llamado ErbB1/HER1) es de especial interés para el presente trabajo. Los restantes miembros de esa subclase son el ErbB2/Neu/HER2, el ErbB3/HER3 y el Erb4/HER4. Todos ellos tienen en común un dominio extracelular de unión a ligando, una región transmembrana y un dominio citoplasmático con propiedades tirosina-quinasa. Una familia de ligandos, conocida como "factores de crecimiento peptídicos relacionados al EGF", se une al dominio extracelular de los receptores ErbB dirigiendo la formación de homo y heterodímeros. La dimerización estimula la actividad tirosina-quinasa intrínseca de los receptores, produciendo la autofosforilación de residuos de tirosina específicos dentro del dominio citoplasmático. Estos residuos fosforilados sirven como sitios de anclaje para moléculas involucradas en la regulación de las cascadas de señalización intracelulares. Por último, los efectos corriente abajo (como las modificaciones en la expresión génica) determinan la respuesta biológica a la activación del receptor [1].

El EGFR en particular está involucrado en numerosos procesos celulares, tanto en un contexto fisiológico como patológico. Participa en la proliferación y diferenciación celular, así como también en los procesos de migración y adhesión. La activación del EGFR es importante además para la respuesta inmune innata en la piel y para la angiogénesis. La desregulación del receptor (en particular su hiperactividad) a su vez está relacionada con diversas patologías, como cáncer (especialmente los epiteliales, de pulmón y glioblastoma), enfermedades inflamatorias (como psoriasis y arteriosclerosis), fibrosis renal y enfermedades cardíacas.

\subsection{Estructura de los receptores ErbB.}

Pese a que existen variaciones en la capacidad de unión a ligando y en la actividad tirosinaquinasa, la estructura general de los dominios del EGFR es compartida por los 4 receptores ErbB (Figura 1). Todos son proteínas modulares largas, que están glicosiladas en sus dominios extracelulares y tienen un peso molecular de $180 \mathrm{kDa}$ [2]. 


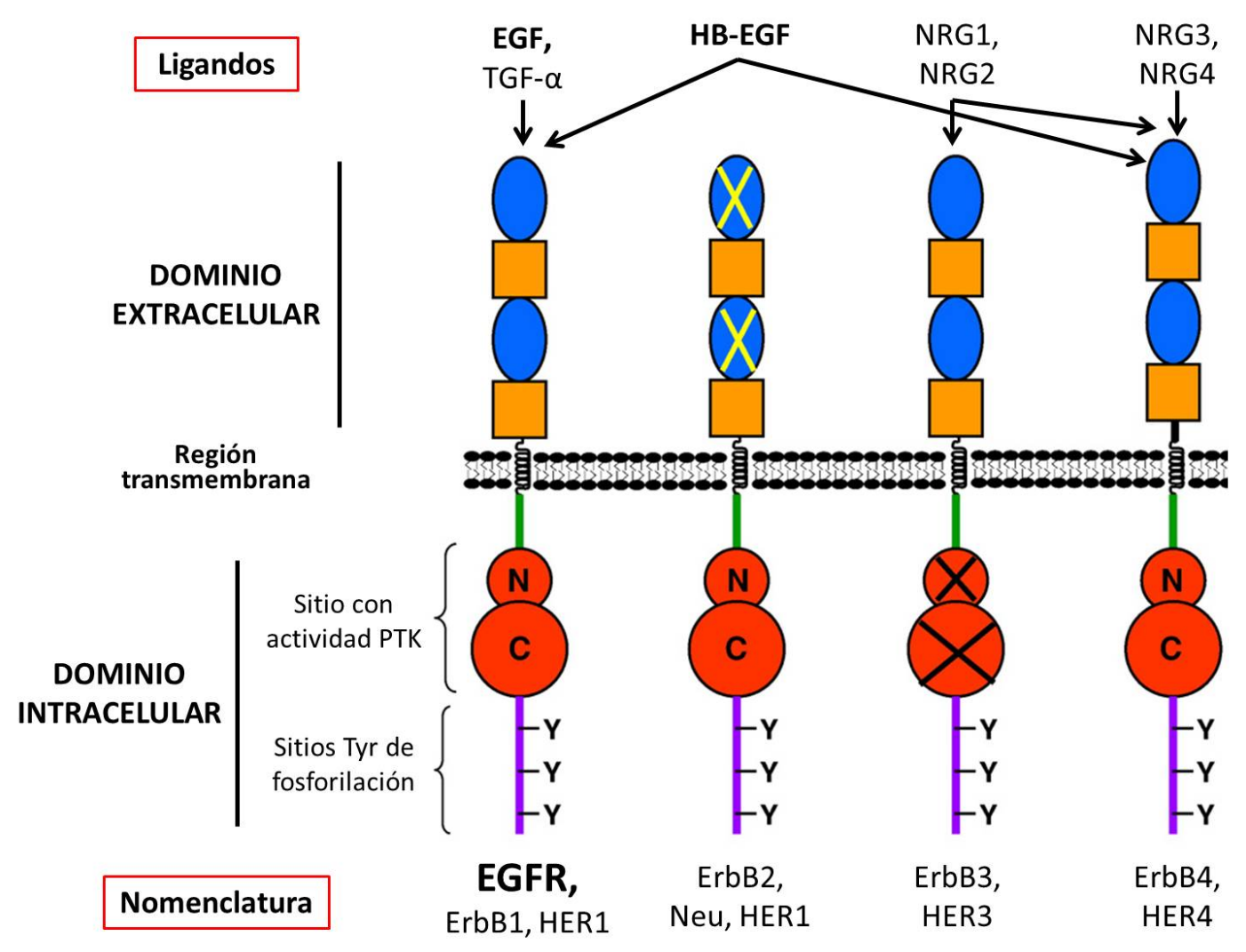

Figura 1. Familia de receptores ErbB. Las cruces en el dominio de unión a ligando del ErbB2 indican la falta de ligandos para este receptor, y en el dominio tirosina-quinasa del ErbB3 indican su falta de funcionalidad. Adaptado de [3].

El EGFR es sintetizado como un pro-receptor, que incluye un péptido señal para dirigirlo a su localización celular correcta en la membrana plasmática. La proteína madura de 1186 residuos (Figura 1) consiste en un dominio extracelular N-terminal (residuos 1-621), un dominio transmembrana simple (residuos 622-644), y una región intracelular que contiene un sub-dominio yuxtamembrana (residuos 645-684), un sub-dominio intracelular con actividad tirosina-quinasa (residuos 685-953) y una región regulatoria C-terminal no catalítica (residuos 954-1186) [4, 5]. El dominio extracelular glicosilado está formado por 4 sub-dominios, 2 de los cuales son homólogos ricos en Leucina que consisten en $\beta$-hélices plegadas (llamados I y III), mientras que los 2 restantes son ricos en Cisteína y están unidos entre sí por puentes disulfuro (llamados II y IV) [4, 5]. El dominio transmembrana es rico en aminoácidos hidrofóbicos y está flanqueado en el sitio intracelular por una región yuxtamembrana que tiene un rol regulatorio en la función del receptor. El subdominio catalítico con actividad tirosina-quinasa (PTK) es una estructura bilobular inusual, dado que a diferencia de otros miembros de la familia de receptores tirosina-quinasa, no requiere la fosforilación de un residuo tirosina conservado (Tyr845) para promover la actividad PTK. La región C-terminal contiene gran cantidad de residuos tirosina, que son fosforilados en la activación del receptor [3]. 


\subsection{Activación del EGFR.}

El mecanismo de activación del EGFR ha sido estudiado en detalle. La homodimerización o la heterodimerización con otro miembro de la familia ErbB es esencial para la iniciación de la cascada de señales pero, inusualmente para los receptores de la familia tirosina-quinasa, estudios cristalográficos de rayos $\mathrm{X}$ mostraron que los ligandos se unen a un solo receptor, induciendo la posterior dimerización [2, 4]. En el estado auto-inhibido (en ausencia de ligando extracelular), los subdominios I y III del dominio extracelular se mantienen separados por la presencia de una traba intramolecular entre los dominios II y IV, lo que mantiene al dominio extracelular en una conformación cerrada (Figura 2). Los ligandos se unen de forma independiente al subdominio I o al III con baja afinidad, causando un cambio en la conformación del receptor. Esta modificación estructural resulta en una unión de afinidad elevada del ligando a ambos subdominios, y en la ruptura de la atadura intracelular entre los subdominios II y IV. El cambio conformacional también expone un "brazo de dimerización" presente en el subdominio II (residuos 242-259 en el EGFR), permitiendo la subsecuente homo o heterodimerización [4, 5].

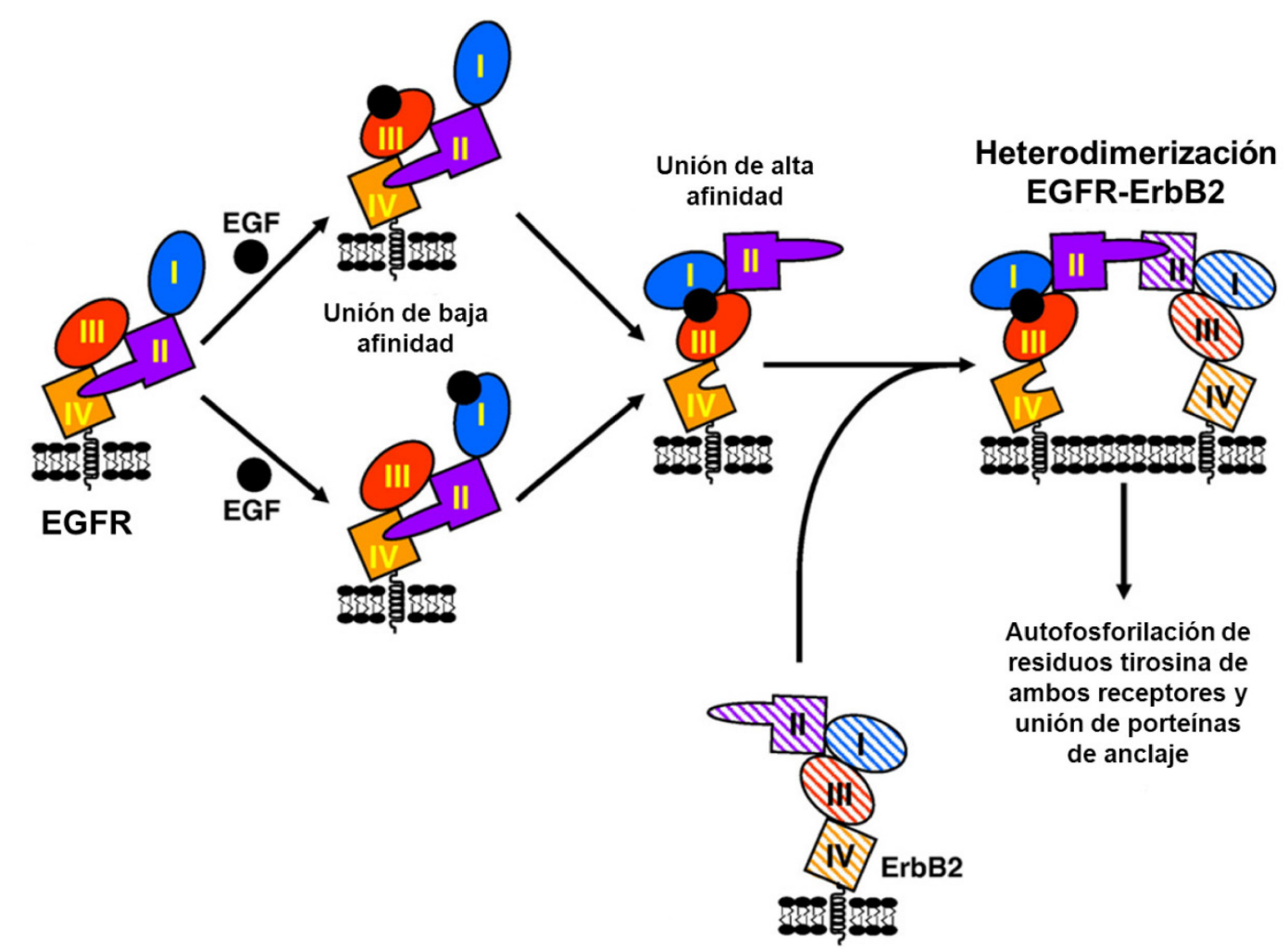

Figura 2. Activación de receptores ErbB. El cambio conformacional por la unión del ligando rompe la traba molecular entre los subdominios II y IV y expone el brazo de dimerización. Esquematización de formación de un heterodímero EGFR-ErbB2. Adaptado de [3].

La dimerización también juega un papel importante en la estimulación de la actividad PTK intracelular del EGFR. En el estado monomérico, el subdominio PTK se encuentra en una 
conformación inactiva auto-inhibida [6, 7]. En el proceso de dimerización, la actividad de PTK aumenta localmente cuando se forman dímeros PTK asimétricos. El lóbulo $\mathrm{C}$ de un monómero (monómero 1) se une al lóbulo $\mathrm{N}$ de otro monómero (monómero 2), y el monómero 1 actúa como un activador alostérico del monómero 2, induciendo cambios conformacionales que fuerzan al monómero 2 a adoptar la conformación correcta para la catálisis (lóbulos $\mathrm{C}$ y $\mathrm{N}$ indicados con las letras correspondientes en la región con actividad PTK de la Figura 1) [7, 8]. Múltiples residuos tirosina en la región C-terminal del EGFR son trans-fosforilados por la actividad del subdominio PTK en el dímero de receptores, y actúan como sitios de anclaje para la unión de proteínas efectoras [9].

\subsection{Trans-activación del EGFR.}

Además de la activación directa del EGFR por unión de sus ligandos, existe un proceso de activación muy estudiado, denominado trans-activación, en el cual el receptor es activado por señales provenientes de los receptores acoplados a proteína G (GPCRs). Estos GPCRs son receptores de membrana, involucrados en la regulación de diversas funciones en el organismo e implicados en numerosas rutas de señalización intracelular [10]. En el año 1996 se mostró por primera vez que el tratamiento de fibroblastos de rata con lipopolisacárido, endotelina-1 o trombina provocaba la fosforilación del EGFR y la subsecuente activación de sus efectores de señalización [11]. Desde ese entonces, se ha estudiado la trans-activación del EGFR por numerosos ligandos, tales como la prostaglandina E2 [12], la leptina [13] y la angiotensina II [14] entre otros.

Cabe destacar que dada la importancia de los agonistas mencionados en los procesos inflamatorios, en la diabetes y en la señalización cardiovascular respectivamente, la transactivación es un fenómeno de especial relevancia.

En cuanto al mecanismo molecular que involucra la trans-activación, hay 2 vías propuestas. Existen evidencias de una vía "independiente de ligando" donde la señal entre el GPCR activado y el EGFR es solamente intracelular, y a cargo de la familia de proteínas tirosina-quinasas Src [15], que fosforilan directamente al receptor (línea discontinua de la Figura 3). Pero la vía más estudiada es aquella "dependiente de ligando" (Figura 3), donde la activación del GPCR provoca a su vez la activación de una metaloproteasa de membrana, que cliva un pro-ligando (el HB-EGF definido en el siguiente apartado) en el ligando activo, que se une al receptor [16]. Esta secuencia de eventos da lugar al modelo conocido como "señalización por triple paso de membrana", dado que la señal ingresa a la célula por el GPCR, vuelve a salir de la misma por la metaloproteasa y la liberación del ligando activo, y reingresa por el EGFR. Cabe destacar que la participación de los otros ErbBs no ha sido estudiada en este proceso. 


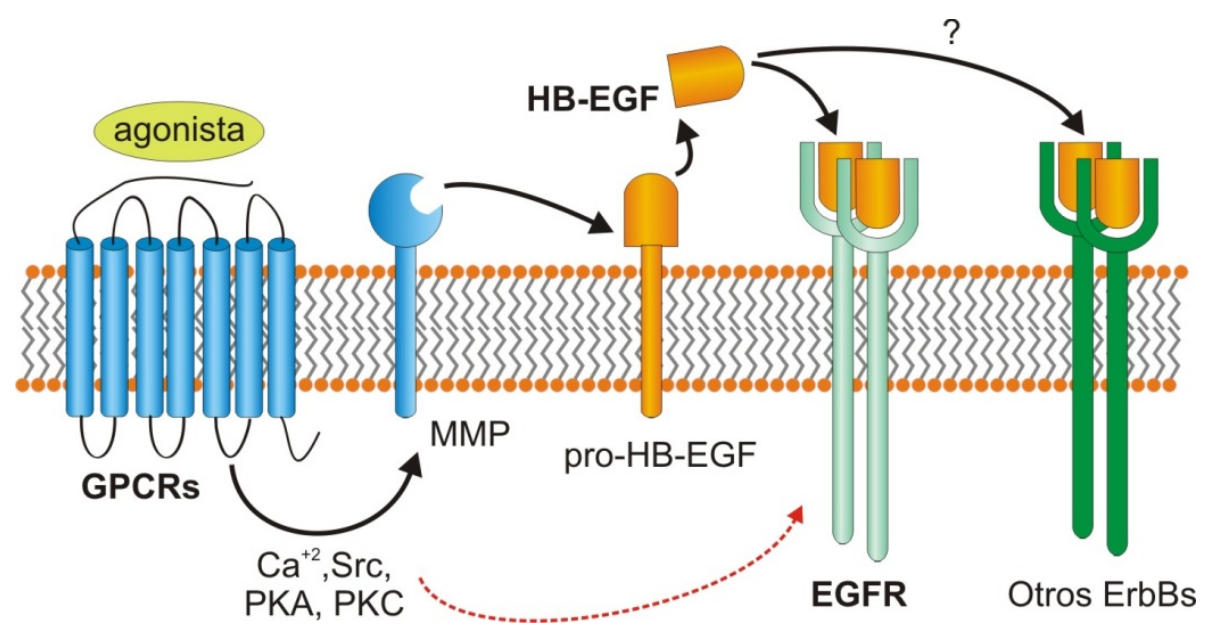

Figura 3. Trans-activación del EGFR por GPCR. Los agonistas activan al GPCR, que a su vez provoca la liberación/activación de varios mensajeros intracelulares. En la vía "independiente de ligando" (línea discontinua roja) estos mismos ligandos activan al EGFR. En la vía "dependiente de ligando", activan a una metaloproteasa, que cliva el pro-ligando en ligando activo, que se une y activa al receptor.

\subsection{Ligandos extracelulares de los receptores ErbB.}

Los 4 receptores ErbB presentan un gran número de ligandos peptídicos extracelulares que se unen a uno o más de los receptores (Figura 1). Los pro-ligandos son usualmente sintetizados como precursores transmembrana que son luego clivados proteolíticamente, para liberar los ligandos solubles $[17,18]$. Los ligandos ErbB de elevada afinidad tienen un dominio "símil-EGF" compuesto por 6 residuos Cisteína que forman tres puentes disulfuro intracelulares, definiendo una estructura secundaria con tres horquillas. El EGF (factor de crecimiento epidérmico), el TGF- $\alpha$ (factor de crecimiento transformante alfa), el HB-EGF (factor de crecimiento tipo EGF unido a heparina), la anfiregulina, la betacelulina y la epiregulina se unen al EGFR. Sin embargo, mientras que el EGF, el TGF- $\alpha$ y la anfiregulina se unen exclusivamente al EGFR, los otros 3 ligandos también activan al receptor ErbB4 (Figura 1). Una familia de ligandos, conocida colectivamente como neuregulinas (NRGs), se une al ErbB3 y al ErbB4.

\subsection{Receptores ErbB y sus ligandos en el corazón.}

La mayoría de los receptores ErbB y muchos de sus ligandos son importantes en el desarrollo del corazón en etapas embrionarias. Los miocitos (células cardíacas) de ratas neonatas y adultas expresan transcriptos de EGFR, ErbB2 y ErbB4, pero los transcriptos del ErbB3 no han podido ser detectados [19, 20].

Por lo tanto en el corazón adulto las posibilidades de formación de homodímero se restringen a homodímeros del EGFR y del ErbB4 (el ErbB2 al no tener funcionalidad en el dominio 
de unión a ligando necesita sí o sí formar un heterodímero), mientras que las heterodimerizaciones posibles son EGFR-ErbB4, EGFR-ErbB2 y ErbB2-ErbB4 (Figura 4).

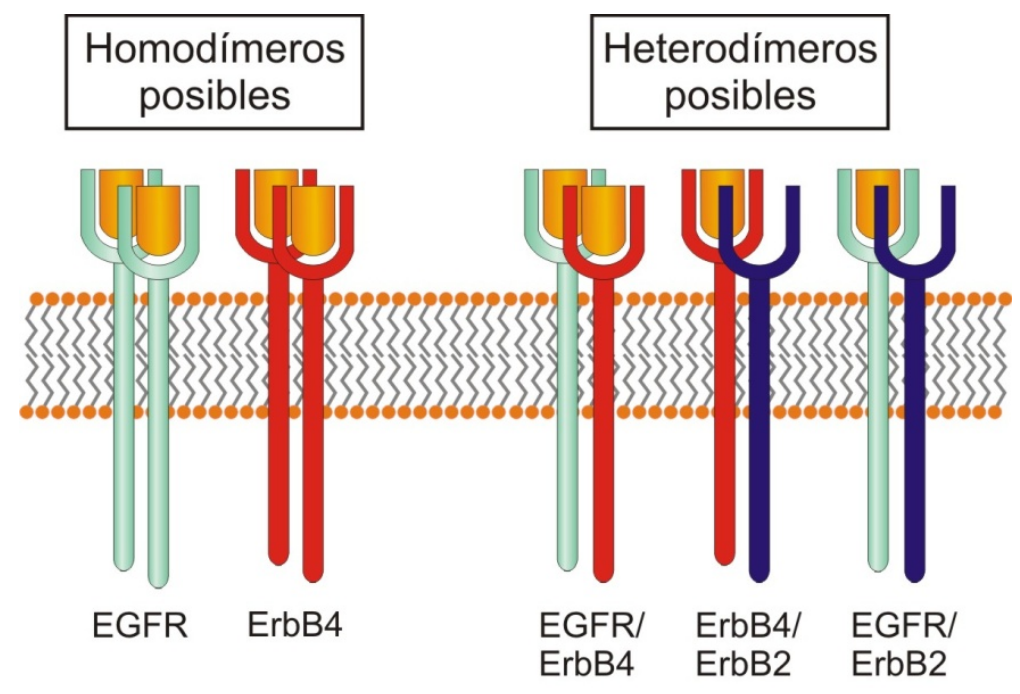

Figura 4. Posibilidades de dimerización en corazón adulto de rata.

En cuanto a los ligandos, los miocitos de ratas neonatas y adultas expresan transcriptos de EGF y NRG1 [19], así como también del HB-EGF [21]. Una consideración adicional es que los receptores ErbB no están uniformemente distribuidos en la membrana plasmática de los miocitos cardíacos, sino que están localizados en regiones específicas [22, 23].

\section{Rutas de señalización disparadas por el estiramiento cardíaco.}

El estiramiento del músculo cardíaco, considerado una señal temprana disparadora de hipertrofia cardíaca (HC), promueve la formación y liberación de factores neuro-humorales prohipertróficos, como Angiotensina II (Ang II), Endotelina-1 (ET-1) y Aldosterona (Ald), que activan vías de señalización intracelular que involucran el aumento de la producción de especies reactivas derivadas del oxígeno (ROS), fundamentalmente de origen mitocondrial, y que confluyen en la activación del intercambiador $\mathrm{Na}^{+} / \mathrm{H}^{+}$(NHE1).

La actividad exacerbada del NHE1 en el miocardio ha sido vinculada al desarrollo de distintas patologías que se caracterizan por un crecimiento anormal del tejido, en particular el remodelamiento post-infarto de miocardio y la HC [24], condiciones ambas que pueden conducir a la insuficiencia cardíaca seguida de muerte. Se ha demostrado que la hiperactividad del NHE1 conduce al aumento de la concentración intracelular de $\mathrm{Na}^{+}$y consecuentemente de $\mathrm{Ca}^{2+}$ a través del intercambiador $\mathrm{Na}^{+} / \mathrm{Ca}^{2+}$ (NCX), favoreciendo la activación de señales intracelulares disparadoras de transcripción génica y síntesis proteica, y determinando así el desarrollo de HC. Además de estos efectos a largo plazo, este aumento de la concentración de $\mathrm{Ca}^{2+}$ intracelular es el responsable en lo inmediato de la segunda fase de fuerza post-estiramiento del miocardio (SFF) o efecto Anrep, que se manifiesta luego del aumento de fuerza inicial debido al mecanismo de 
Frank-Starling (Figura 5). La similitud entre los mecanismos agudos que conducen a la SFF y las señales intracelulares que conducen a la HC han hecho del efecto Anrep un buen modelo para analizar la fisiopatología cardiovascular [25, 26]. Este concepto se refuerza en el hecho de que muchas de las intervenciones que cancelan la SFF y se enumeran en la Figura 5B han sido usadas exitosamente para prevenir la HC [27-32].

A
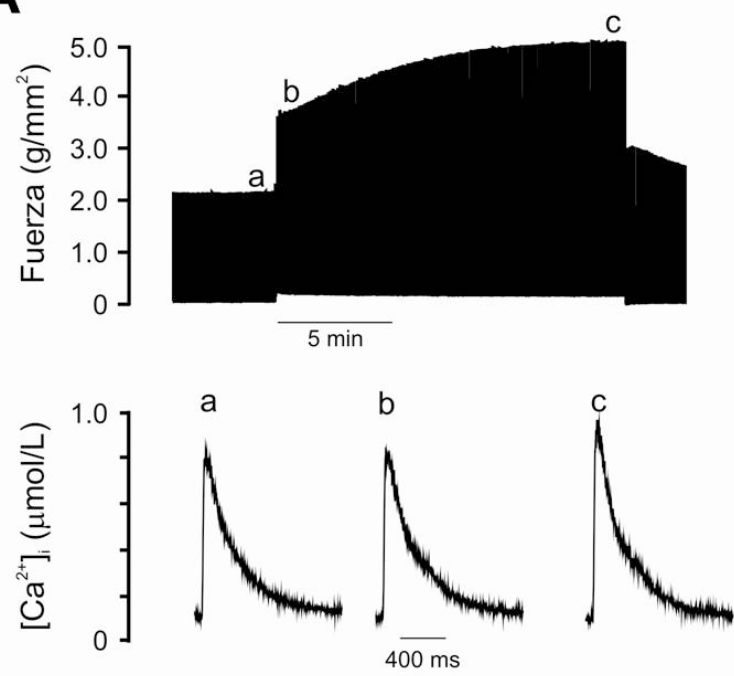

B

Intervenciones farmacológicas que previenen la SFR o efecto Anrep

-Bloqueo de receptores AT1 de Ang II (losartan)

-Bloqueo de receptores ETA de ET (BQ123)

-Bloqueo de receptores MR de Ald (eplerenone)

-Bloqueo de receptores EGFR de EGF (AG1478)

-Prevención de ROS (MPG, apocinina, 5HD)

-Inhibición del NHE1 (cariporide)

-Bloqueo del NCX (KBR7943)

Figura 5. Segunda fase de fuerza al estiramiento. A. Trazado de fuerza contráctil de un músculo papilar aislado mostrando la primera fase de aumento de fuerza o mecanismo de Frank-Starling, de "a" a " $\mathrm{b}$ ", que se produce sin cambios en el $\mathrm{Ca}^{2+}$ intracelular (panel inferior), y la SFF, de "b" a "c", debida a un aumento del $\mathrm{Ca}^{2+}$ intracelular. B. Intervenciones farmacológicas que previenen la SFF, muchas de las cuales han sido usadas con éxito para prevenir la HC.

La SFF ha sido el foco de interés de numerosas proyectos de investigación del CIC, lo que ha permitido sugerir que el estiramiento dispara una ruta de señalización cuyos principales pasos se esquematizan en la Figura 6. Así mismo, varias líneas de investigación se han dedicado a estudiar nuevas estrategias terapéuticas para prevenir la hiperactivación crónica del NHE1 y el consecuente desarrollo de $\mathrm{HC}$, mediante intervenciones que afecten alguno de los eslabones de esta vía de señalización intracelular. En tal sentido, se ha descubierto que la activación postestiramiento del EGFR podría ser un paso clave en la ruta ROS-dependiente de activación de quinasas redox-sensibles (ERK1/2-p90RSK), cuyo blanco de fosforilación (y por lo tanto activación) es el NHE1, y cuyo resultado final es la SFF. Dado que estos resultados se han obtenido usando herramientas farmacológicas para bloquear al EGFR, y este tipo de intervenciones suelen tener un cierto grado de inespecificidad que no solo cuestiona la validez de los resultados sino que a su vez condiciona su potencial uso terapéutico, el desarrollo de un RNA de interferencia contra el EGFR que sea capaz de silenciarlo, permitiría contar con una herramienta para probar de manera más específica que el EGFR se activa post-estiramiento del miocardio. Esta estrategia no solo permitiría corroborar si el EGFR se encuentra en la ruta de activación del NHE1 en respuesta al mencionado estímulo mecánico, como se propone en la Figura 6, sino que además, como consecuencia de ello, podría sentar las bases para su utilización como posible herramienta 
terapéutica anti-hipertrófica.

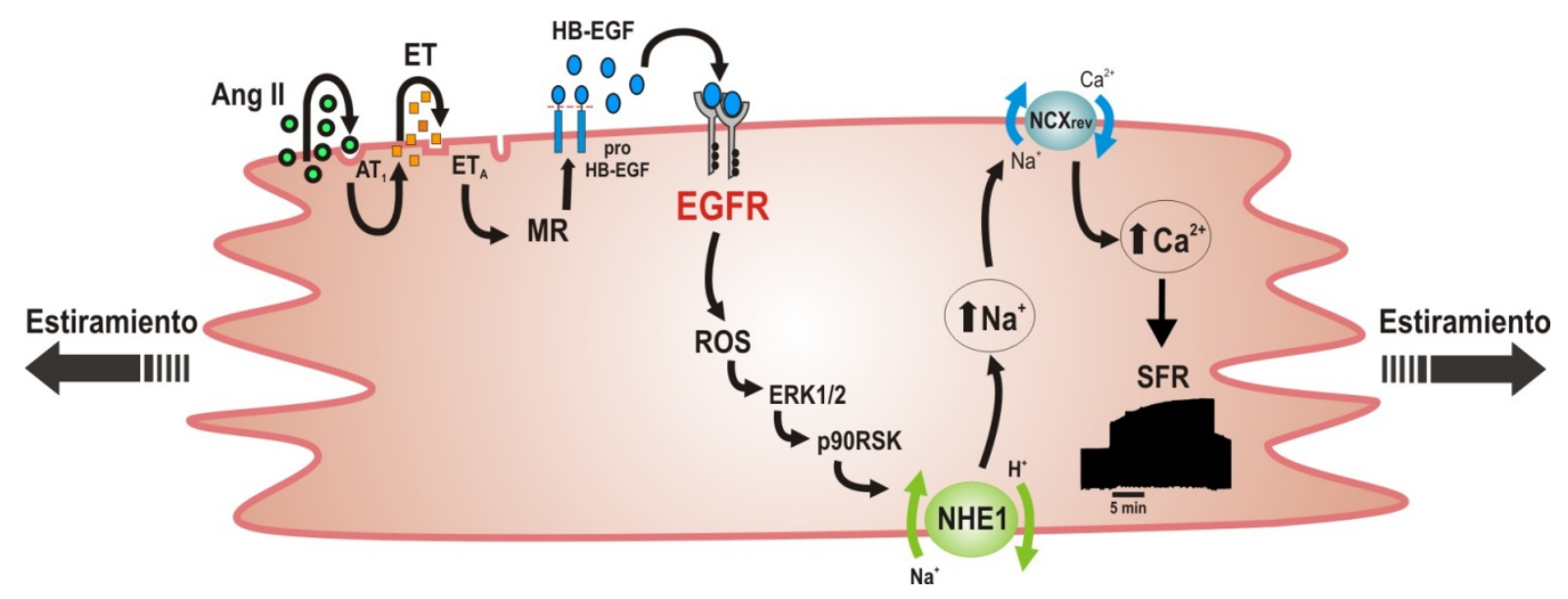

Figura 6. Representación esquemática de la ruta disparada por estiramiento. El estiramiento del músculo provoca liberación de Ang II, que por acción sobre su receptor AT1 provoca liberación de ET-1. Esto activa al receptor de mineralocorticoides (MR) que provoca el clivaje del pro-HB-EGF en HB-EGF y la trans-activación del EGFR. La activación del receptor provoca un aumento de ROS que activa quinasas redox-sensibles, que fosforilan al NHE1. La activación del intercambiador carga el interior celular de $\mathrm{Na}^{+}$, lo que provoca que el NCX funcione en modo reverso, sacando el $\mathrm{Na}^{+} \mathrm{e}$ ingresando $\mathrm{Ca}^{2+}$. Este incremento de $\mathrm{Ca}^{2+}$ es el responsable del aumento de la fuerza.

\section{Hipertrofia cardíaca.}

\subsection{Epidemiología.}

Según los últimos reportes de la Organización Mundial de la Salud (Mayo 2017, [33]), las enfermedades cardiovasculares (ECV) son la principal causa de muerte a nivel mundial, habiendo provocado 17,7 millones de muertes en el año 2015, lo que representa el $31 \%$ de las muertes globales. Le siguen el cáncer (8,8 millones), las enfermedades respiratorias (3,9 millones) y la diabetes (1,6 millones). La Argentina sigue el mismo perfil: del total de muertes por enfermedades no transmisibles, el 35\% corresponde a muertes por enfermedades cardíacas, seguido por cáncer (21\%), enfermedades respiratorias crónicas (7\%) y diabetes (3\%) (Figura 7) [34].

Dado que el total de muertes por ECV aumenta año a año, la OMS tiene como política bajar los factores de riesgo para estas enfermedades. La hipertrofia cardíaca patológica es considerada actualmente un factor de riesgo independiente para morbilidad y mortalidad de origen cardiovascular en adultos [35, 36], de modo que la caracterización precisa de las bases fisiopatológicas que llevan a su desarrollo constituye un paso clave para el diseño de terapias de prevención y/o reversión de la misma. 


\section{Argentina}

Total population: 41087000

Income Group: Upper middle

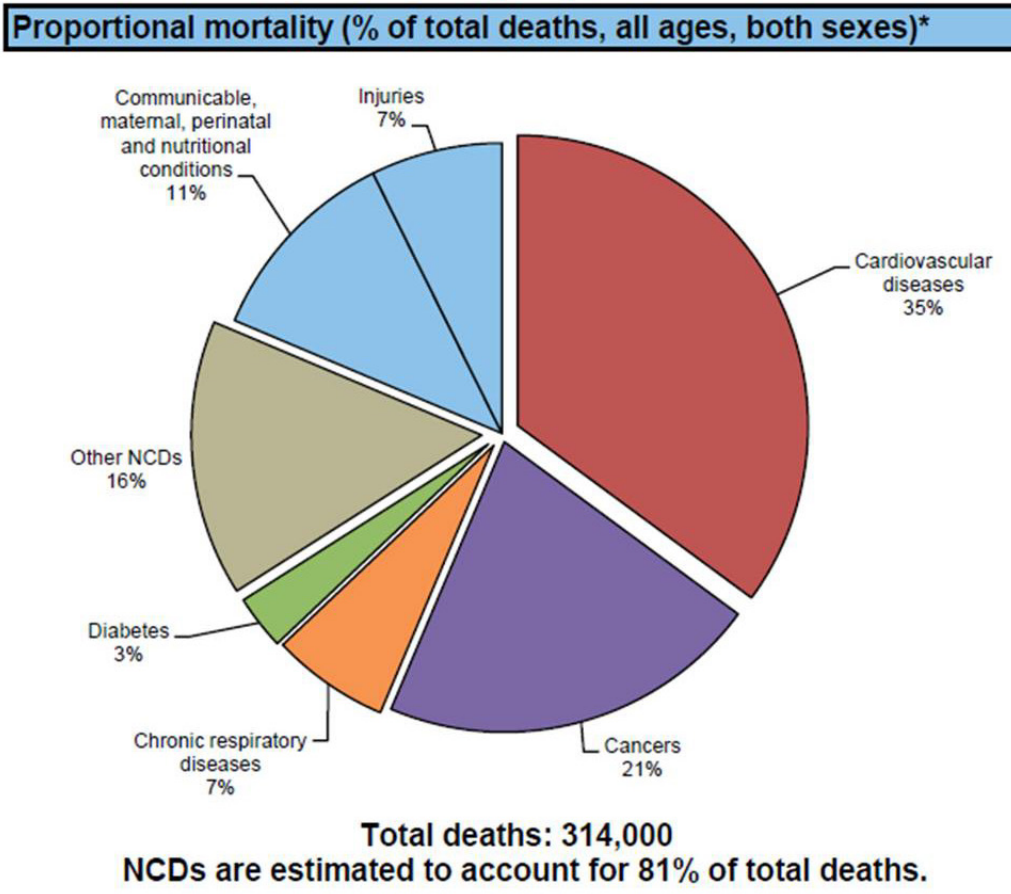

Figura 7. Porcentaje de muertes por enfermedades no transmisibles en Argentina. Según datos de la OMS, el 35\% de las muertes por enfermedades no transmisibles en Argentina se deben a enfermedades cardiovasculares.

\subsection{Definición y clasificaciones.}

La hipertrofia cardíaca $(\mathrm{HC})$ se define clásicamente como un aumento de la masa ventricular en respuesta a una situación de sobrecarga hemodinámica. Cuando esa respuesta se caracteriza por un aumento del tamaño de los cardiomiocitos con incremento proporcional de la vasculatura, sin aumento de la fibrosis intersticial, y sin compromiso funcional, el proceso se denomina hipertrofia cardíaca fisiológica (HCF). Esta respuesta cumple una función realmente adaptativa, y es común en el crecimiento, el embarazo, y la práctica de actividad física intensa. Sin embargo, algunas hipertrofias se acompañan de aumento de fibrosis intersticial, mayor incidencia de apoptosis, disminución de la irrigación y la densidad capilar, y reprogramación de la expresión génica, con inducción de genes fetales y represión de genes de expresión característica en adulto. Esta variante se denomina hipertrofia cardíaca patológica (HCP), dado que las alteraciones en el miocardio que la caracterizan se asocian con deterioro de la función ventricular y evoluciona habitualmente a insuficiencia cardíaca. Las poblaciones de hipertensos [37, 38] o de pacientes con episodios isquémicos agudos [39, 40] presentan en general HCP con pronóstico desfavorable hacia la insuficiencia.

A nivel del cardiomiocito, la HCP cursa con un aumento del área celular y una mayor incidencia de apoptosis [41]. En términos energéticos, hay un cambio en el sustrato de oxidación, 
de ácidos grasos a carbohidratos [42]. Esto explica el hecho de que el corazón hipertrofiado sea un órgano energéticamente comprometido, con una disminución en la producción de ATP, dado que la oxidación de una molécula de ácido graso produce mucho más ATP ( 129) que la de la glucosa ( 36). Por otra parte, la baja en el consumo de ácidos grasos provoca una acumulación inapropiada de lípidos en el cardiomiocito, lo que resulta en disfunción contráctil [43]. Estas respuestas del miocito en la HCP se deben a la re-expresión del programa génico fetal, lo que implica de modo resumido [44]:

$\checkmark$ Aumento global de la expresión de genes (en particular los que codifican para colágeno, proteínas contráctiles y canales y transportadores iónicos).

$\checkmark$ Re-expresión de genes no expresados en adultos (como la cadena pesada de la $\beta$-miosina, la óxido nítrico sintasa neuronal, péptidos natriuréticos, y genes de la vía de apoptosis).

$\checkmark$ Represión de genes no expresados en el período fetal (como la SERCA2, la cadena pesada de la $\alpha$-miosina, la subunidad $\beta 1$ de los receptores adrenérgicos, los receptores muscarínicos, y la mioglobina).

\subsection{Participación del EGFR en la HCP.}

La Ang II es un conocido agente inductor de remodelado cardíaco, HCP y fibrosis, y en los últimos años se ha vinculado su acción sobre el EGFR con estos efectos (Figura 8). Los primeros estudios que usaron una secuencia antisentido dirigida contra el EGFR mostraron una supresión de la hipertrofia ventricular izquierda en ratas SHR y en ratas Wistar con infusión de Ang II [30, 45]. Por otro lado, ratones que sobre expresan el receptor RALT, que es un inhibidor fisiológico de la señalización por EGFR, no desarrollan HCP frente al estímulo con Ang II [46]. Utilizando la línea celular cardíaca $\mathrm{H} 9 \mathrm{c} 2$, un estudio reciente mostró que la inhibición específica del EGFR revierte la fosforilación de ERK1/2 y Akt producida por Ang II, así como también revierte el aumento de expresión de proteínas correspondientes a genes fetales y de aumento característico en la HCP, como ANP y BNP [47].

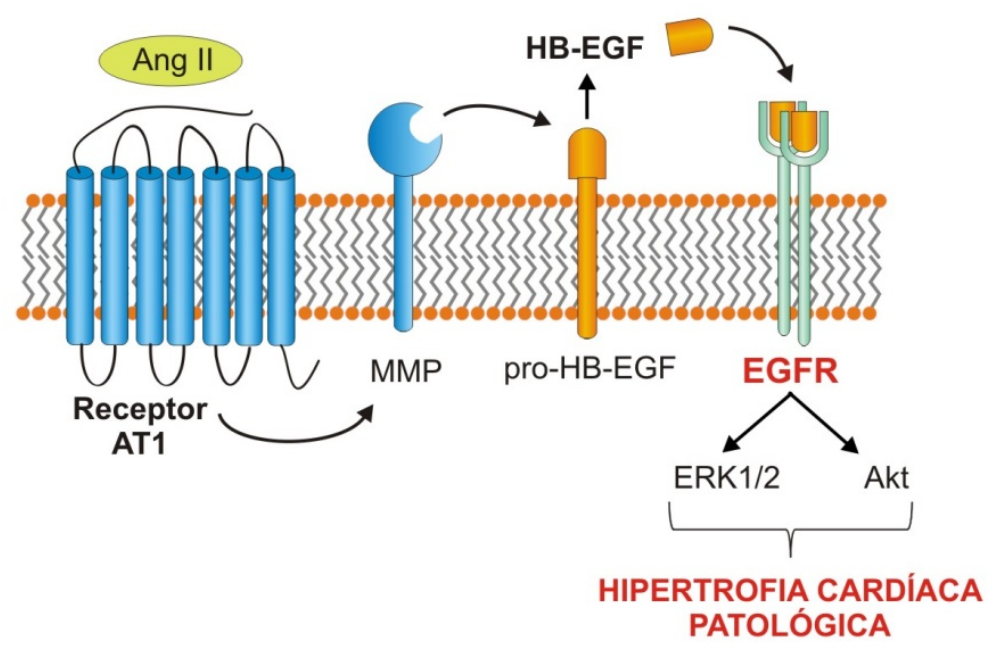

Figura 8. Esquema de la ruta propuesta que vincula la trans-activación con la generación de HCP. 
Estudios en ratones transgénicos con una mutación en el sitio del receptor de Ang II AT1 que está involucrado en la trans-activación del EGFR, mostraron que la falta de este motivo derivó en una falta de respuesta hipertrófica frente al estímulo con Ang II, en comparación con los ratones salvajes [14]. Sin embargo, este mecanismo de trans-activación que implica la fosforilación del AT1 no pudo ser demostrado en estudios posteriores en cardiomiocitos neonatales de rata [48], y se propuso en cambio que lo fundamental para que la señal se transmita desde el AT1 al EGFR es el acoplamiento de la proteína G del GPCR. Independientemente del mecanismo, hay suficiente evidencia para vincular al EGFR con la generación de HCP inducida por Ang II.

\subsection{Hipertrofia y estrés oxidativo.}

El estrés oxidativo ocurre cuando se genera un exceso de ROS que no puede ser compensado por los sistemas antioxidantes intrínsecos. La producción de ROS es un componente normal de los sistemas fisiológicos, y en pequeñas cantidades actúan como segundos mensajeros y mediadores de rutas de señalización [49]. Sin embargo una producción excesiva dispara la disfunción celular, la peroxidación lipídica y el daño a nivel de DNA, llevando a un daño irreversible de la célula y a la muerte (Figura 9) [49].

Las ROS incluyen tanto radicales libres, como el anión superóxido y el radical hidroxilo, como compuestos que pueden ser convertidos en radicales, como es el caso del peróxido de hidrógeno. El superóxido es producido principalmente por activación de las enzimas NADPH oxidasas (NOX), por las xantina oxidasas, por desacople de la óxido nítrico sintasa o por el pasaje de los electrones en la cadena transportadora mitocondrial (Figura 9) [49]. A su vez la célula cuenta con sistemas antioxidantes que, en condiciones fisiológicas, pueden contrarrestar la producción exacerbada de ROS [50].

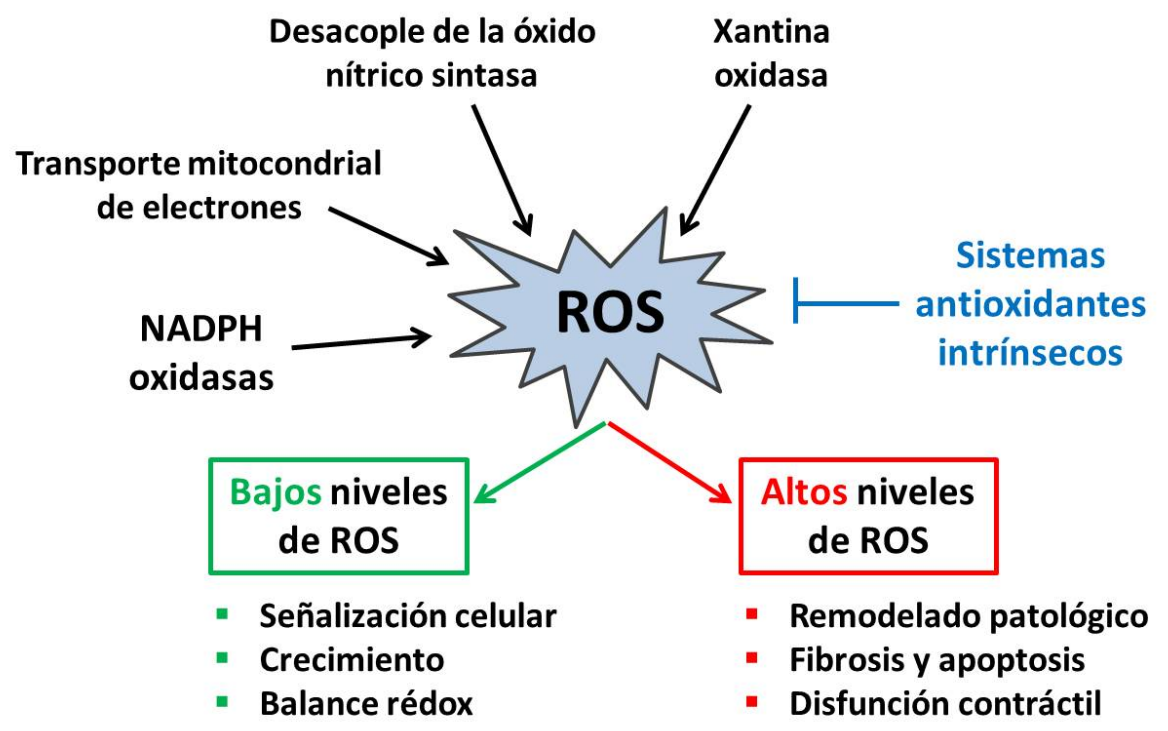

Figura 9. Esquema de las fuentes de producción de ROS, y las consecuencias fisiopatológicas del balance. 
Las ROS activan una amplia variedad de quinasas y factores de trascripción que son fundamentales en el desarrollo de la $\mathrm{HCP}$ [31]. En cardiomiocitos neonatales de rata, el $\mathrm{H}_{2} \mathrm{O}_{2}$ estimula proteínas como Src y PKC, mediadores intracelulares del proceso de trans-activación del EGFR [51]. Las ROS en general, por su parte, están involucradas en la estimulación de los GPCR por Ang II [52] y estímulos adrenérgicos [53], ambos estímulos pro-hipertróficos. Por otro lado, el balance de ROS tiene un potente efecto sobre la matriz extracelular, estimulando la proliferación de los fibroblastos cardíacos [54] y activando las metaloproteasas [55], provocando un aumento en la fibrosis y un remodelado estructural de la matriz. Por último, las ROS pueden influir directamente en la función contráctil modificando proteínas centrales en el proceso de acoplamiento excito-contráctil [56].

De todas las fuentes intracelulares de producción de anión superóxido, las NOXs son de especial interés en este trabajo. Son enzimas multiméricas compuestas de forma general por dos subunidades catalíticas de membrana (gp91 ${ }^{\text {hox }}$ y p22 $^{\text {phox }}$ ) y 4 subunidades citosólicas regulatorias (p40phox, p47phox, p67phox y la proteína Rac) [57]. Hay en total 5 isoformas de NOX, de las cuales las dos más expresadas en el corazón son las NOX2 y la NOX4 [57]. Se sabe que la actividad y expresión de las NOXs aumentan por estímulos como el factor de necrosis tumoral $\alpha$ [58] y agonistas $\alpha$-adrenérgicos [59], así como también en animales sujetos a una sobrecarga de presión [60] y en la falla cardíaca en humanos [61]. En particular, las ROS generadas por las NOXs parecen tener un papel fundamental en la HCP inducida por Ang II, aunque no está claro cuáles son las isoformas involucradas. Dosis subpresoras de Ang II inducen una HCP que se cancela en corazones con ausencia de NOX2 [62], mientras que ratones KO de NOX2 desarrollan un menor remodelado luego del infarto de miocardio [63]. Sin embargo, también se ha reportado que ratones con ausencia de NOX2 desarrollan una respuesta hipertrófica a la sobrecarga de presión que es similar a la de los ratones controles, con iguales niveles de disfunción contráctil y fibrosis [64]. Esto implicaría a rutas alternativas u otras isoformas de NOX (como NOX4) en este cuadro.

\section{Silenciamiento génico mediante RNA de interferencia.}

El RNA de interferencia (RNAi) es un fenómeno de silenciamiento génico posttranscripcional, específico de secuencia y evolutivamente conservado. Es disparado por moléculas de RNA doble cadena, tal como fue descripto por primera vez en C. elegans [65].

El silenciamiento por RNAi comprende una vía intracelular de múltiples pasos, que puede ser dividida en 2 fases: la fase de iniciación y la fase efectora. En la fase de iniciación, moléculas de RNA doble cadena largas o moléculas de RNA doble cadena con un pequeño loop (shRNA del inglés short hairpin $R N A$ ), de origen endógeno o exógeno, son procesadas a través de la actividad de clivaje de una proteína tipo ribonucleasa III, denominada Dicer, en fragmentos nucleotídicos de 21-23 nt, denominados RNA de interferencia pequeños (siRNA del inglés small interference RNAs) [66]. Estos siRNAs son incorporados, en el comienzo de la fase efectora, a un complejo multiproteico denominado RISC (complejo de silenciamiento inducido por RNA) [67]. A través del desenrrollamiento del siRNA por medio de una actividad RNA helicasa [68], el complejo se vuelve 
activo y utiliza el siRNA simple hebra como guía hacia el mRNA blanco complementario. Luego de la unión del siRNA a su RNA mensajero blanco por hibridización, una proteína llamada Argonauta-2, dentro del complejo RISC, cataliza el clivaje endonucleotídico de la hebra de RNA mensajero, provocando su rápida degradación (Figura 10). Dado que el complejo RISC se recupera para sucesivos ciclos de unión y clivaje, el proceso completo lleva a una reducción neta de los niveles de mRNA específico, provocando una disminución de la expresión del gen correspondiente.

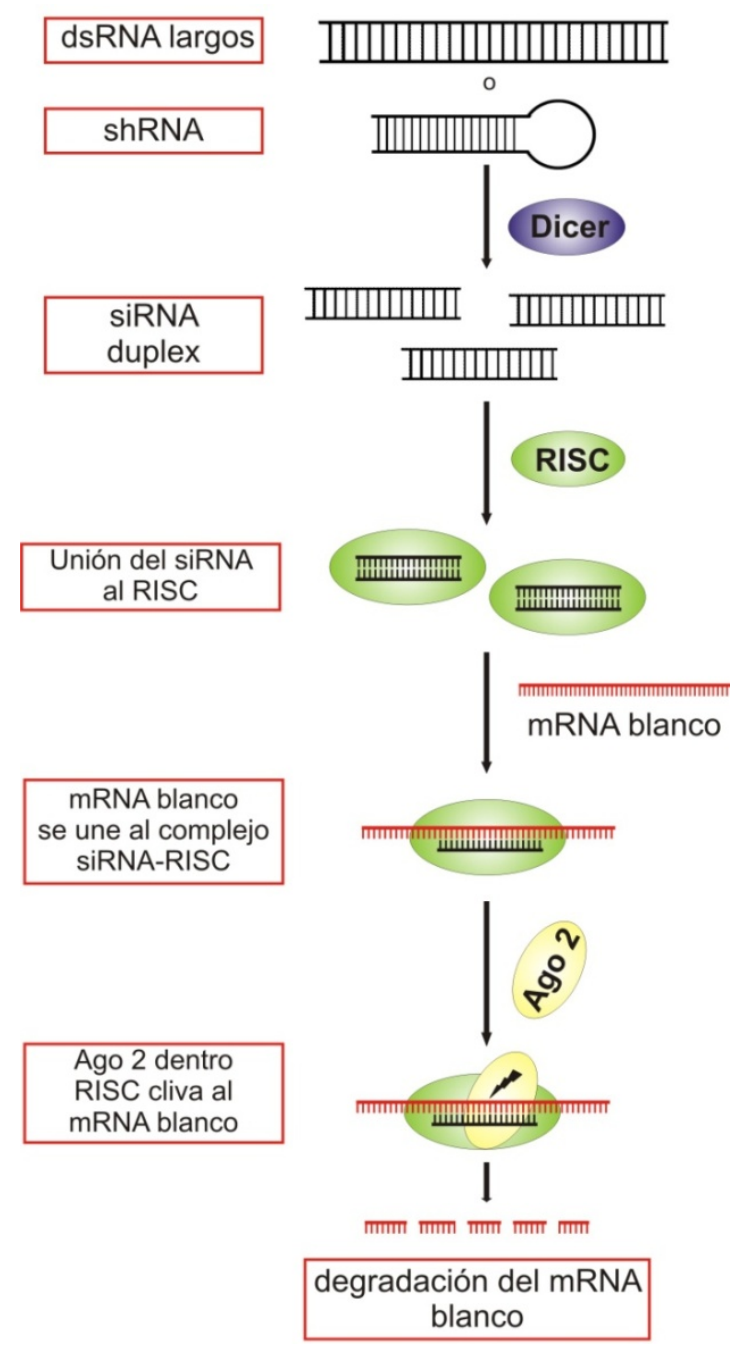

Figura 10. Mecanismo del RNA de interferencia en mamíferos.

En los mamíferos, los siRNAs pueden ser introducidos en las células por transfección transitoria de siRNAs sintéticos $[69,70]$, o por transfección transitoria o estable de construcciones que expresan shRNAs a partir de promotores de la RNA polimerasa III [71-73]. Los dos promotores más comúnmente usados para la expresión de shRNAs son el H1 y el U6 dado que usualmente dirigen la síntesis de snRNA (del inglés small nuclear RNA) y que tienen elevada eficiencia y expresión ubicua. Están adaptados para expresar shRNAs en un cassette de un tamaño aproximado de 60 nucleótidos (nt), que incluyen una secuencia sentido de 21-23 nt que es idéntica a la secuencia blanco en el mRNA a ser degradado, seguida por un loop de 9 nt y una secuencia 
anti sentido de 21-23 nt. Un tramo de 5 timidinas proporciona la señal de terminación transcripcional (Figura 11A). La expresión de esta construcción resulta en un shRNA pequeño de 21-23 nt; el loop es clivado entonces por la endonucleasa Dicer y los siRNAs resultantes disparan la degradación del mensajero blanco [74].

\subsection{Sistema de delivery: lentivirus.}

Los vectores lentivirales derivados del virus de la inmunodeficiencia humana tipo 1 (HIV1) son capaces de transducir una amplia variedad de células en división y terminales (que ya no se dividen), y se integran de forma estable en el genoma del huésped, permitiendo una expresión prolongada del transgén. El genoma del HIV-1 contiene 9 marcos de lectura abiertos que codifican para al menos 15 proteínas distintas, incluyendo proteínas estructurales y regulatorias, que están involucradas en el ciclo de infección. La estrategia general usada para producir partículas de vector lentiviral ha sido eliminar del genoma del HIV-1 todos los elementos que no son absolutamente indispensables para la producción de partículas virales, la infección y la integración [75].

Los vectores lentivirales de tercera generación más comúnmente utilizados consisten en 4 plásmidos (Figura 11). El vector de transferencia (Figura 11A) contiene el transgén de interés, expresado bajo el promotor H1 de la polimerasa III, y el gen codificante de la proteína fluorescente roja DsRed, bajo el promotor de citomegalovirus (CMV). Además porta el elemento WPRE (del inglés woodchuck hepatitis virus regulatory element), que sirve para aumentar la expresión del transgén [76], y una región de polipurina (PPT), para incrementar la eficiencia del transporte nuclear del complejo de pre-integración [77].

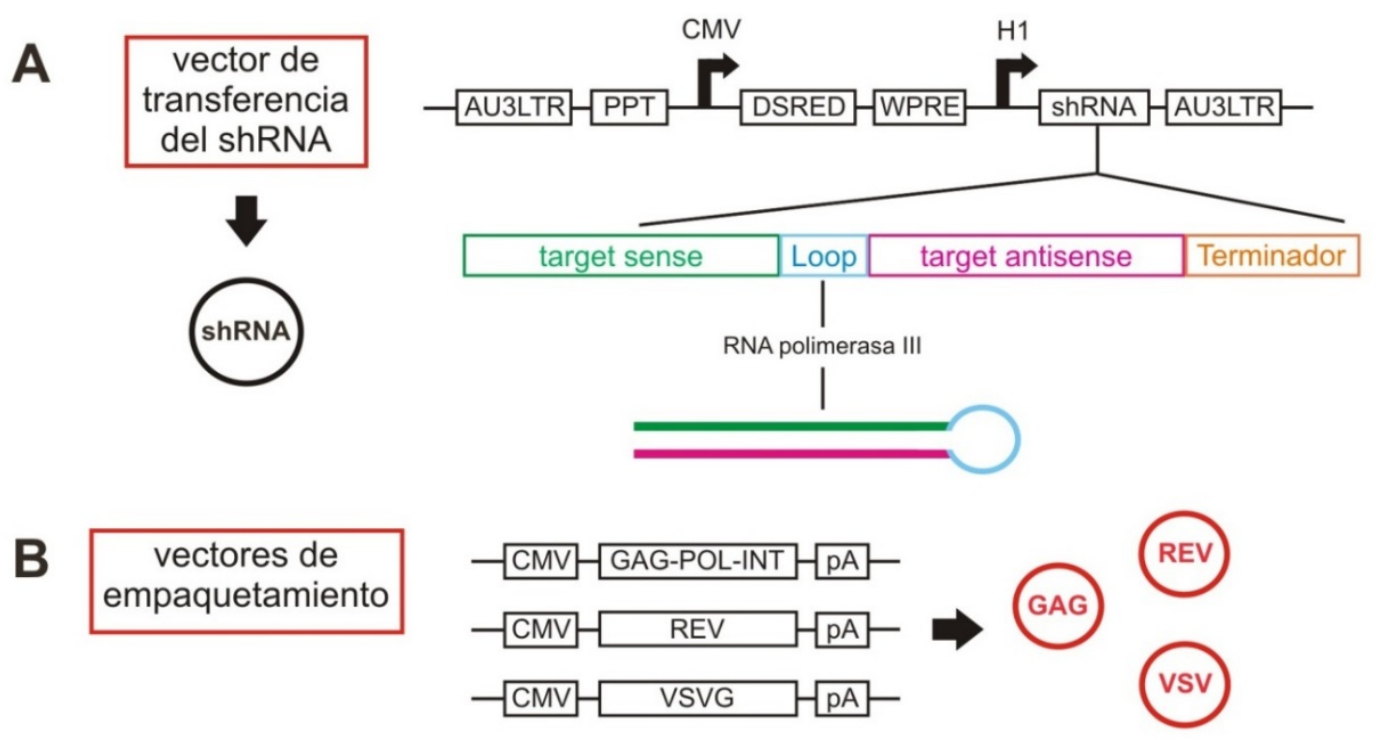

Figura 11. Vectores lentivirales de tercera generación. A. Esquema del vector de transferencia que porta la secuencia del shRNA, además de la proteína fluorescente roja (DsRed). B. Vectores de empaquetamiento, que proveen los factores regulatorios y estructurales. 
El sistema de empaquetamiento involucra 3 plásmidos adicionales que proveen los factores trans requeridos, llamados Gag-Pol, proteína de envoltura y Rev, respectivamente (Figura 11B). Gag-Pol codifica para una integrasa, una transcriptasa reversa, y proteínas estructurales. Las proteínas estructurales son requeridas para la producción de las partículas, mientras que la integrasa y la transcriptasa reversa son empaquetadas dentro de la partícula viral y actúan más adelante en el proceso de infección e integración. Rev interactúa con el elemento de respuesta Rev (RRE), que es una secuencia contenida en el vector de transferencia, que aumenta la exportación del RNA genómico viral del núcleo, favoreciendo el incremento del título viral [75]. Las partículas virales pueden ser tipificadas con una gran variedad de proteínas de envoltura. Una de las más utilizadas es la proteína G del virus de la estomatitis vesicular (VSV-G), la cual es incorporada en la membrana viral y le confiere la habilidad de transducir una gran variedad de tipos celulares [75]. 


\section{HIPÓTESIS Y OBJETIVOS}

La HCP, cualquiera sea su origen, es un factor de riesgo per se de falla cardíaca y muerte de origen cardiovascular. Esto ha hecho que el estudio de las vías de señalización que conducen a la HCP haya tomado especial auge en los últimos años como base para el desarrollo de nuevas alternativas terapéuticas para prevenirla. La Ang II es un conocido agente pro-hipertrófico que desencadena en el miocito cardíaco una serie de eventos intracelulares que aún hoy no están completamente dilucidados. En este marco, el rol de las ROS ha recibido especial atención, y entre los eventos que participarían en el disparo de su generación estaría la trans-activación del EGFR.

La hipótesis a probar mediante el presente proyecto es que Ang II, por un mecanismo que incluye la activación EGFR, genera ROS que activarían las quinasas redox-sensibles que conducen a la hipertrofia. Dado que no hay antecedentes de que estos hallazgos se hayan comprobado in vivo, nuestros objetivos serán comprobar la hipótesis anterior y en este contexto caracterizar el rol del EGFR. Para ello se propone:

1. Desarrollar una herramienta para silenciar el EGFR de forma específica, y probar su funcionalidad en un sistema in vitro.

2. Estudiar la participación del EGFR en la SFF disparada por Ang II in vivo, evaluando su función en la activación del NHE1 y la producción de especies reactivas del oxígeno.

3. Evaluar el rol del EGFR en la HCP inducida en el animal in vivo por Ang II. Establecer en este modelo si el silenciamiento del EGFR conduce a una mejora de la función cardíaca.

4. Estudiar el/los mecanismos por los cuales la Ang II activa al EGFR, y a su vez cómo ésta activación conduce a la liberación de ROS. 


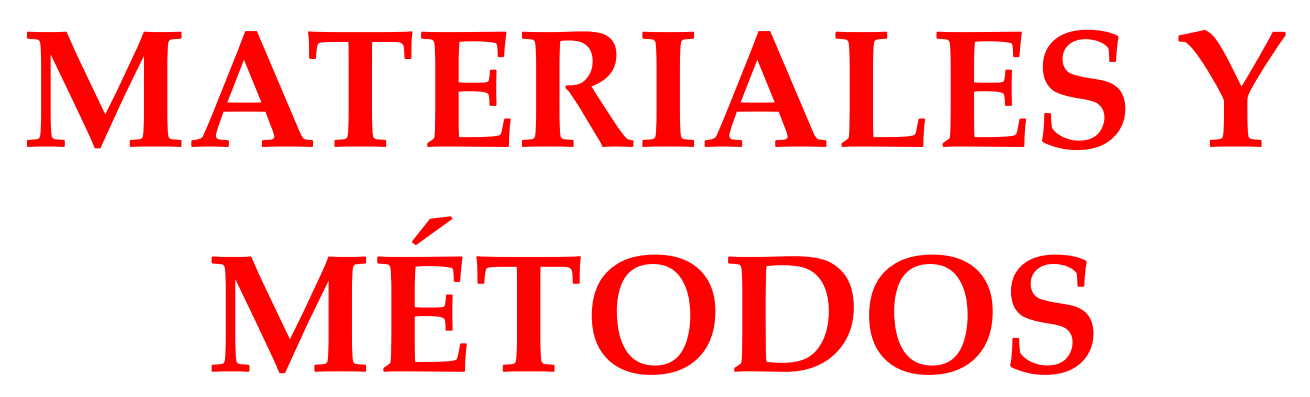


Las composiciones de los buffers y soluciones usadas, así como las secuencias de los primers y la preparación de los anticuerpos, se detallan en el Anexo.

\section{MODELOS EXPERIMENTALES.}

\subsection{Línea celular HEK 293T.}

La línea celular HEK $293 \mathrm{~T}$ fue mantenida en condiciones de temperatura $\left(37^{\circ} \mathrm{C}\right)$ y tensión de $\mathrm{CO}_{2}(5 \%)$ constantes. Las células fueron cultivadas en medio Eagle modificado por Dulbecco (DMEM, Microvet), suplementado con 10\% (v/v) de suero fetal bovino (Natocor) y 1\% (v/v) de los antibióticos penicilina y streptomicina (Life Technologies). Se las mantuvo en placas de $100 \mathrm{~mm}$ y fueron subcultivadas una vez por semana. Para el subcultivo se retiró el medio de cultivo, se lavó la monocapa de células con PBS y se agregó 0,5 ml de tripsina 0,25\% en EDTA (Life Technologies). La acción de la tripsina se terminó por adición de $5 \mathrm{ml}$ de medio de cultivo, y las células se dispersaron por pipeteo. Una décima parte del volumen se colocó en una placa nueva y se agregaron $10 \mathrm{ml}$ de medio. Todo el material de cultivo fue esterilizado por autoclave o por filtración en el caso de los medios de cultivo.

\subsection{Rattus norvegicus.}

Todos los procedimientos llevados a cabo durante la investigación fueron conformes a la Guía de Cuidado y Uso de Animales de Laboratorio, publicada por el Instituto Nacional de Salud (NIH No. 85-23, revisado en 1996), y siguiendo las directrices establecidas por el Comité de Bienestar Animal de la Facultad de Medicina de La Plata.

Para los experimentos de silenciamiento in vivo del EGFR, caracterización funcional del receptor y desarrollo de hipertrofia con bombas infundiendo Ang II se utilizaron ratas Wistar

provenientes del Bioterio Central de la Facultad de Ciencias Médicas. Se trabajó con machos de 4 meses de edad al inicio de cada tratamiento, que fueron mantenidos en cuartos con temperatura controlada $\left(23^{\circ} \mathrm{C}\right)$, ciclos de luz/oscuridad de 12 hs y agua y alimento ad libitum.

Para los experimentos en un modelo genético de hipertrofia cardíaca se utilizaron ratas SHR (del inglés "spontaneously hypertensive rats"). Se trabajó con machos de 3 meses de edad al inicio del tratamiento. Las condiciones de mantenimiento de los animales fueron las mismas que para las ratas Wistar.

\section{CLONADO DEL ShRNA.}

\subsection{Diseño del shRNA-EGFR y shRNA-SCR.}

Para diseñar el RNA de interferencia, lo primero que se hizo fue buscar en bibliografía secuencias que hubieran sido utilizadas para silenciar el EGFR con éxito. La secuencia elegida fue extraída del trabajo de Feng y col. [78], quienes la utilizaron para disminuir la expresión del EGFR 
en miocardio de rata:

\section{5' - GCATAGGCATTGGTGAATT -3'}

A continuación, se verificó mediante el programa BLAST (NCBI) que la secuencia elegida fuera específica del EGFR y no silenciara ningún otro componente del genoma de rata. El genoma elegido para el alineamiento fue el de la especie Rattus norvegicus, el set de búsqueda se limitó a la opción "RefSeq RNA" (secuencias de RNA que están alistadas y verificadas), y el programa elegido fue el "blastn", que busca todas las secuencias nucleotídicas similares. Una vez finalizadas las pruebas sobre la secuencia inhibidora, se procedió a la confección de la secuencia "scramble", que denominaremos "SCR", la cual consiste en una secuencia de la misma longitud y con las mismas bases que la secuencia codificante pero en orden aleatorio, por lo que no silencia ningún elemento del genoma. Para obtener la secuencia scramble se trabajó con la herramienta "online" "siRNA design center" de GenScript (www.genscript.com), programa que al introducir la secuencia inhibidora del EGFR sugirió la siguiente secuencia scramble:

\section{5' - ATGGCATTGCGATAAGTTG -3'}

Se realizó un análisis con el BLAST de la secuencia obtenida, para confirmar que no inhibiera ningún elemento de forma específica.

Luego de obtenerse la secuencia silenciadora del EGFR y la SCR, se procedió a diseñar los shRNA, adicionando los elementos necesarios para su funcionamiento intracelular: una secuencia "loop" o bucle, fundamental para la formación del "hairpin"; un terminador de la transcripción, y los sitios de corte para las enzimas de restricción utilizadas en el proceso de clonado, BamHI y PacI. Además se agregó un sitio de corte de EcoRI entre el terminador y el sitio de PacI, para mejorar el screening del clonado. Con todos estos elementos, la secuencia final del shRNA-EGFR se detalla en la Figura 12.

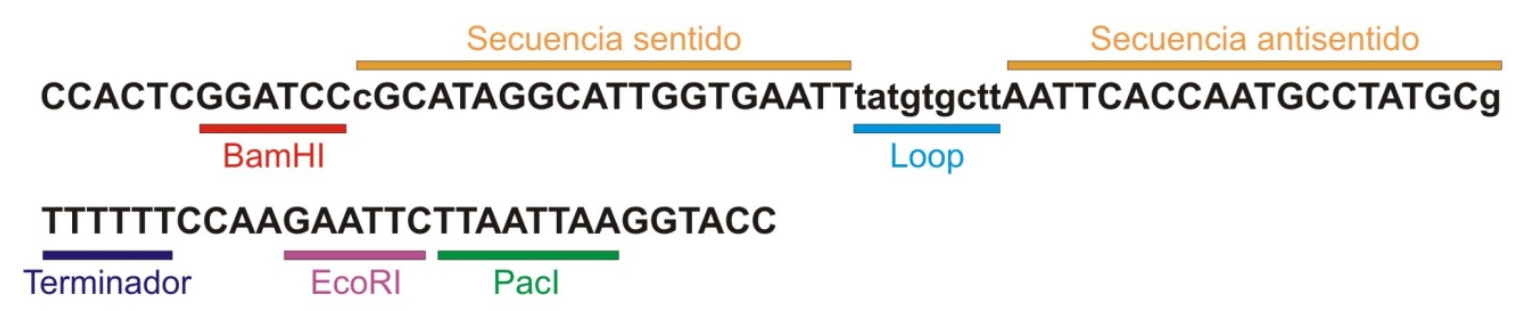

Figura 12. Esquema de la secuencia codificante del shRNA-EGFR con todos los elementos característicos. BamHI y PacI corresponden a los sitios de corte de las enzimas de clonado; EcoRI es el sitio de corte de la enzima usada para el estudio de inserción.

Tanto esta secuencia final como la del SCR (detallada en el Anexo 1) fueron utilizadas para un análisis con la herramienta OligoAnalyzer 3.1 (Integrated DNA Technologies), a fin de simular el hairpin correspondiente a cada secuencia, y estudiar sus propiedades. 


\subsection{Generación del inserto de clonado.}

\subsubsection{Reacción de "annealing".}

La reacción de annealing es aquella mediante la cual secuencias complementarias de DNA simple cadena se unen mediante enlaces por puente de hidrógeno, para formar una molécula doble cadena. En el presente trabajo, el inserto doble cadena se formó por annealing de 2 primers complementarios. Se utilizaron primers preparados por la empresa Invitrogen para formar el shRNA-EGFR y el shRNA-SCR (secuencias en el Anexo 1).

Para el annealing, la mezcla de reacción se realizó colocando $10 \mu \mathrm{l}$ de EGFR sentido (50 $\mu \mathrm{M}), 10 \mu \mathrm{l}$ de EGFR anti sentido $(50 \mu \mathrm{M}), 2 \mu \mathrm{l}$ de $\mathrm{NaCl}(100 \mathrm{mM})$ y $0,4 \mu \mathrm{l}$ de EDTA $(1 \mathrm{mM})$. Se calentó la mezcla a $95{ }^{\circ} \mathrm{C}$ por $4 \mathrm{~min}$, y luego se enfrió rápidamente a temperatura ambiente (5-10 min). Se realizó una dilución 1/100 de la mezcla, que se utilizó para correr un gel de agarosa 4\%, y a su vez se realizó una dilución 1/100 de la primera dilución para llevar a cabo el clonado. Se repitió el proceso con las secuencias SCR. La formación del DNA doble hebra se verificó a través de geles de agarosa.

\subsubsection{Electroforesis en geles de agarosa.}

Para la preparación de los geles de agarosa se utilizó Agarosa A0100 (Inbio Highway) en una concentración entre 0,5-4\%, según el tamaño del fragmento de DNA a separar, en buffer TAE. Las muestras se prepararon para la corrida agregando distintos volúmenes de Loading Buffer $6 \mathrm{X}$ (Fermentas) y 1-2 $\mu \mathrm{l}$ del colorante GelRed ${ }^{T M}$ Nucleic Acid Gel Stain (Biotium). Como marcador de peso molecular se utilizó GeneRuler ${ }^{T M} 100$ bp DNA Ladder (Fermentas), GeneRuler ${ }^{T M} 1$ Kb DNA Ladder (Fermentas) o GeneRulerTM Ultra Low Range DNA Ladder (ULR, Fermentas), según sea el tamaño del DNA a analizar. La corrida se realizó con buffer TAE a 100V, y el resultado se visualizó por transiluminación UV (Chemidoc Imaging System, Bio Rad).

\subsubsection{Digestión enzimática del inserto.}

Las enzimas utilizadas para el clonado fueron BamHI y PacI (New England Biolabs). El inserto fue digerido en primera instancia con BamHI, colocando por cada tubo $2 \mu \mathrm{l}$ del inserto, $2 \mu \mathrm{l}$ de Buffer NEB 3, 0,2 $\mu$ l de seroalbúmina bovina (BSA, New England Biolabs), $2 \mu$ l de enzima y 13,8 $\mu \mathrm{l}$ de agua (para un volumen final de $20 \mu \mathrm{l}$ ). Se incubaron las muestras por $1 \mathrm{~h}$ a $37^{\circ} \mathrm{C}$. Para la digestión con PacI se agregaron $3 \mu \mathrm{l}$ de buffer NEB 1, 0,3 $\mu$ l de BSA y $2 \mu 1$ de enzima, y se incubó por $1 \mathrm{~h}$ a $37^{\circ} \mathrm{C}$.

\subsubsection{Purificación del inserto digerido.}

La purificación del inserto digerido se realizó empleando el kit comercial HiYield ${ }^{T M}$ Gel/PCR DNA Extraction Kit (BioAmerica). Se agregaron a la muestra de DNA 5 volúmenes de buffer DF y se mezcló con el vortex. Se introdujo una columna DF en un tubo de $2 \mathrm{ml}$ y se transfirió la muestra. A continuación se centrifugó $30 \mathrm{~s}$ a $13.000 \mathrm{rpm}$ (en una centrífuga HERMLE Z 233M), se descartó el eluato que quedó en el tubo y se volvió a colocar la columna. Se agregaron $600 \mu \mathrm{l}$ de Wash Buffer (con etanol), se dejó reposar por $1 \mathrm{~min}$, y luego se centrifugó 30 s a 13.000 rpm. Se centrifugó 3 min 
más para descartar todo el etanol y secar la columna, se pasó la columna a un nuevo tubo de 1,5 ml y se eluyó en $30 \mu \mathrm{l}$ de Tris-HCl. Se dejó reposar durante 2 min y luego se centrifugó 2 min a 13.000 rpm. Así se obtuvo el inserto digerido y purificado, en un volumen final de $30 \mu l$.

\subsubsection{Cuantificación del producto digerido.}

Los productos digeridos y purificados fueron cuantificados por espectrofotometría en el equipo NanoDrop 2000c (Thermo Scientific), utilizando $1 \mu \mathrm{l}$ de agua como blanco y $1 \mu \mathrm{l}$ de muestra para la medición. La densidad óptica se midió a $260 \mathrm{~nm}$ (la constante del equipo para el DNA doble cadena a esa longitud de onda es $1 \mathrm{DO}=50 \mu \mathrm{g} / \mathrm{ml})$.

\subsection{Generación del vector de clonado.}

\subsubsection{Vector utilizado para el clonado.}

El vector lentiviral utilizado en este trabajo se denomina $\mathrm{PPPT}$, tiene un tamaño aproximado (no poseemos el mapa) de 7.500 pb, y fue donado por el doctor Eduardo Marban [79], quien lo modificó en su laboratorio a partir del plásmido original creado por el laboratorio del doctor Inder Verma (Salk Institute, La Jolla, California). Este plásmido contiene un cassette con una secuencia shRNA inhibitoria flanqueada por los sitios de corte para las enzimas BamHI y PacI y precedida por el promotor H1 de la RNA polimerasa III. Además, tiene un gen reportero que codifica para la proteína fluorescente roja DsRed, que se expresa bajo el promotor de citomegalovirus CMV. A fin de facilitar el proceso de selección, posee un gen que codifica para una proteína que confiere resistencia al antibiótico ampicilina.

\subsubsection{Digestión enzimática del vector.}

Las reacciones de digestión con las enzimas de clonado BamHI y PacI se llevaron a cabo en volúmenes variables de entre 20 a $50 \mu \mathrm{l}$ dependiendo de la concentración del DNA a digerir. Se emplearon en general entre 2-4 $\mu$ g de DNA por tubo, y los cortes fueron secuenciales, es decir que se cortó el vector primero con BamHI, se purificó y se cortó con PacI. Las digestiones fueron corroboradas en geles de agarosa de $0,5-0,8 \%$, con el marcador de peso molecular $1 \mathrm{~Kb}$ DNA Ladder (Fermentas).

\subsubsection{Purificación del vector digerido.}

La purificación se realizó con el kit comercial HiYield ${ }^{T M}$ Gel/PCR DNA Extraction Kit (BioAmerica).Se realizó una electroforesis en un gel de agarosa $(0,6 \%)$ de la mezcla de digestión, y luego por medio de transiluminación con UV se identificó la banda en el gel y se cortó el fragmento correspondiente. Se transfirió la banda a un tubo de 1,5 ml, se agregaron $500 \mu \mathrm{l}$ de buffer de disolución y se incubó a $55-60{ }^{\circ} \mathrm{C}$ por 15 min (hasta disolución total de la agarosa). Posteriormente se transfirieron $800 \mu \mathrm{l}$ de la muestra disuelta a una columna de purificación. Se centrifugó 30 s a 13.000 rpm, se descartó el eluato y se volvió a poner la columna en el tubo. Se lavó la muestra en la columna con $400 \mu \mathrm{l}$ de Buffer W1, se centrifugó por 30 s a 13.000 rpm y se descartó 
el eluato. Se lavó por segunda vez con $600 \mu \mathrm{l}$ de Wash Buffer (con etanol), se dejó reposar 1 min y se centrifugó por $30 \mathrm{~s}$ a $13.000 \mathrm{rpm}$. Luego se centrifugó otros $3 \mathrm{~min}$ a $13.000 \mathrm{rpm}$ para eliminar todo el etanol y secar la columna. Se transfirió la columna a un tubo nuevo de 1,5 ml, y se agregaron $30 \mu \mathrm{l}$ de buffer Tris-HCl para recuperar el DNA. Finalmente, se centrifugó por 2 min a $13.000 \mathrm{rpm}$, obteniéndose el vector purificado en un volumen final de $30 \mu \mathrm{l}$.

\subsubsection{Cuantificación del producto digerido.}

De la misma manera que para el inserto, el vector se cuantificó por medición de la densidad óptica a $260 \mathrm{~nm}$ en el equipo NanoDrop 2000c (Thermo Scientific), utilizando $1 \mu \mathrm{l}$ de agua como blanco y $1 \mu$ de muestra para la medición.

\subsection{Ligación del inserto al vector.}

La enzima utilizada para la ligación fue la T4 DNA ligasa (Invitrogen). Las relaciones molares vector : inserto ensayadas fueron 1:50, 1:10 y 1:3. El volumen de reacción fue de $20 \mu l$, utilizando $4 \mu \mathrm{l}$ de Buffer de ligación 5X y $1 \mu \mathrm{l}$ de T4 DNA ligasa (1U/ $\mu \mathrm{l})$. Se ligó toda la noche a temperatura ambiente.

En todas las reacciones se incluyó un control positivo de ligación, que consistió en el vector pPPT cortado con una sola enzima de restricción (y por lo tanto con los extremos cohesivos complementarios) y re-ligado, sin el inserto y con la T4 DNA ligasa. Por otro lado, se incluyó un control negativo, que consistió en el vector pPPT cortado con las 2 enzimas de restricción (y por lo tanto con extremos cohesivos no compatibles), sin el agregado de inserto, y con el agregado de T4 DNA ligasa.

\subsection{Producción y purificación del vector de transferencia clonado.}

\subsubsection{Bacterias E. coli DH5- $\alpha$.}

E. coli DH5- $\alpha$ es la cepa de E. coli más usada para clonado molecular. Son bacterias que se transforman con elevada eficiencia, y poseen muchas características que las hacen útiles para los métodos que implican la presencia de DNA recombinante: la mutación endA1 inactiva una endonucleasa intracelular que degrada el DNA plasmídico; la mutación hsdR17 elimina la endonucleasa de restricción del sistema de modificación-restricción EcoKI, y por lo tanto los fragmentos de DNA que poseen metilaciones en los sitios EcoKI no son degradados; y la mutación recA elimina la posibilidad de recombinación homóloga.

\subsubsection{Transformación de bacterias electrocompetentes.}

El proceso de transformación implica la introducción de DNA exógeno a una célula bacteriana. Para la transformación con la construcción recombinante obtenida se utilizaron las bacterias E. coli DH5- $\alpha$ electrocompetentes. El equipo utilizado para llevar a cabo la transformación 
fue un Electroporador BioRad, modelo Micropulser ${ }^{T M}$. Se tomó un volumen entre 2-4 $\mu$ l de las ligaciones, se adicionó a tubos con 50-100 $\mu \mathrm{l}$ de bacterias, y se colocó la mezcla en cubetas de $0,1 \mathrm{~cm}$ de espacio entre electrodos, previamente enfriadas en hielo. Luego se introdujo la cubeta en el equipo y se dio un pulso eléctrico de 1,8 kV. Inmediatamente se resuspendieron las bacterias en $600 \mu \mathrm{l}$ de medio SOC y se transfirieron a un tubo estéril. Se crecieron a $37^{\circ} \mathrm{C}$ con agitación por $1 \mathrm{~h}$, y luego se sembraron 100 $\mu \mathrm{l}$ de bacterias transformadas en placas de LB agar suplementadas con ampicilina (100 $\mu \mathrm{g} / \mathrm{ml})$. Se incubaron a $37^{\circ} \mathrm{C}$ en estufa durante la noche.

\subsubsection{Aislamiento del vector: Miniprep.}

Para extraer el DNA plasmídico de un cultivo pequeño de bacterias se utilizó la técnica de Miniprep, y el kit comercial illustra plasmidPrep Mini Spin Kit (GE Healthcare). Siguiendo las indicaciones del fabricante, una colonia aislada se inoculó en $5 \mathrm{ml}$ de medio líquido LB con $100 \mu \mathrm{g} / \mathrm{ml}$ de ampicilina, y se incubó con agitación durante toda la noche a $37{ }^{\circ} \mathrm{C}$. Al día siguiente se centrifugaron $1,5 \mathrm{ml}$ del cultivo bacteriano a $13.000 \mathrm{rpm}$ por $30 \mathrm{~s}$. Se agregaron $175 \mu \mathrm{l}$ de buffer de lisis tipo 7, y se resuspendieron las bacterias por agitación manual. Se agregaron $175 \mu \mathrm{l}$ de buffer de lisis tipo 8 , y se mezcló por inversión del tubo 5 veces. Se agregaron $350 \mu \mathrm{l}$ de buffer de lisis tipo 9 y se volvió a mezclar invirtiendo el tubo. Se centrifugó la mezcla a $13.000 \mathrm{rpm}$ por $5 \mathrm{~min}$, y se transifirió el sobrenadante a las columnas de purificación del kit, colocadas en tubos colectores. Se centrifugó a $30 \mathrm{~s}$ a $13.000 \mathrm{rpm}$, y se agregaron $400 \mu \mathrm{l}$ de buffer de lavado tipo 1, luego de lo cual se centrifugó $1 \mathrm{~min}$ a $13.000 \mathrm{rpm}$. Se pasó las columnas con el DNA unido a tubos estériles, y se eluyó el plásmido agregando $50 \mu \mathrm{l}$ de buffer de elución tipo 4 y centrifugando 30 s a 13.000 rpm.

\subsubsection{Aislamiento del vector: Maxiprep.}

Para obtener grandes cantidades de plásmido recombinante se llevó a cabo la técnica de Maxiprep. Se inoculó un cultivo de $250 \mathrm{ml}$ de LB-ampicilina con una pre-cultivo de la colonia en $5 \mathrm{ml}$ de LB-ampicilina, crecido ya 24 hs, y se lo creció toda la noche a $37^{\circ} \mathrm{C}$ y $250 \mathrm{rpm}$ de agitación. Al día siguiente se centrifugó el cultivo por $15 \mathrm{~min}$ a $6.000 \mathrm{rpm}$ y $4^{\circ} \mathrm{C}$ en una Sorvall RC-5B, y se descartó el sobrenadante. Se agregaron $10 \mathrm{ml}$ de solución 1 y se resuspendió el precipitado por agitación manual. Se agregó $1 \mathrm{ml}$ de lisozima (10 mg/ml, Sigma Aldrich) y se dejó actuar por $10 \mathrm{~min}$. Se agregaron $10 \mathrm{ml}$ de solución 2 y se mezcló invirtiendo el tubo 5 veces. Se agregaron $10 \mathrm{ml}$ de solución 3 fría, se realizaron 10 inversiones del tubo y se incubó $20 \mathrm{~min}$ en hielo. Se centrifugó por $30 \mathrm{~min}$ a $13.000 \mathrm{rpm}$ y $4^{\circ} \mathrm{C}$, transfiriendo luego el sobrenadante a otro tubo estéril. Se agregaron 0,6 volúmenes de isopropanol, se mezcló por inversión y se dejó $10 \mathrm{~min}$ a temperatura ambiente. Se centrifugó por 30 min a $13.000 \mathrm{rpm}$, se descartó el sobrenadante y se lavó el precipitado con $10 \mathrm{ml}$ de etanol 70\%. Se centrifugó a $13.000 \mathrm{rpm}$ por $10 \mathrm{~min}$, se descartó el sobrenadante y se secó el precipitado invirtiendo los tubos sobre papel. Se resuspendió el DNA en $500 \mu \mathrm{l}$ de buffer Tris- $\mathrm{HCl}$, y a fin de eliminar el RNA que pudo haberse aislado en el proceso, se agregaron $2 \mu \mathrm{l}$ de RNasa (10 $\mu \mathrm{g} / \mu \mathrm{l}$, Sigma Aldrich) y se incubó $1 \mathrm{~h}$ a $55^{\circ} \mathrm{C}$.

\subsubsection{Precipitación fenol-cloroformo.}

Con el objetivo de purificar el DNA plasmídico obtenido, se llevó a cabo una precipitación con fenol-cloroformo comercial (Pierce-Endogen). Partiendo de $X \mu l$ de muestra a purificar, se agregaron 
$X \mu l$ de solución fenol-cloroformo y se mezcló hasta emulsión fina. Se centrifugó 1 min a 13.000 rpm y se transfirió la fase acuosa (donde está contenido el DNA) a un nuevo tubo. Luego se agregaron $X \mu l$ de cloroformo (para extraer el fenol que haya quedado en la solución), se mezcló y se centrifugó 1 min a $13.000 \mathrm{rpm}$. Se trasladó la fase acuosa con el DNA ya purificado a un nuevo tubo, y se procedió a precipitarlo. Para ello se agregaron 1/10 del volumen de la muestra de acetato de sodio $3 \mathrm{~mol} / \mathrm{L}, \mathrm{pH}$ 5,2 y 2-2,5 volúmenes de la muestra de etanol $95 \%$, y se incubó a $-20^{\circ} \mathrm{C}$ por $20 \mathrm{~min}$. Se centrifugó 15 min a $13.000 \mathrm{rpm}$ y $4{ }^{\circ} \mathrm{C}$, y se descartó el sobrenadante. Al precipitado se le agregaron $500 \mu \mathrm{l}$ de etanol $70 \%$ frío, se centrifugó $10 \mathrm{~min}$ a $13.000 \mathrm{rpm}$, se descartó el etanol y se secó por 5 min en mechero. Finalmente se resuspendió el DNA purificado en $500 \mu \mathrm{l}$ de buffer Tris-HCl.

\subsection{Análisis del plásmido vector generado.}

\subsubsection{Reacción de PCR y digestión del amplicón.}

El plásmido obtenido se analizó mediante PCR y posterior digestión enzimática del producto. Se realizó una PCR específica para el vector, utilizando los primers H1F2 y M13, con los cuales se obtiene un fragmento de 900 pb luego de la amplificación. La mezcla de reacción para un volumen final de $25 \mu$ l fue la siguiente:

$\begin{array}{ll}\text { Buffer PCR } & 2,5 \mu \mathrm{l} \\ \text { Primer H1F2 } & 0,05 \mu \mathrm{l} \\ \text { Primer T7 } & 0,05 \mu \mathrm{l} \\ \mathrm{dNTP} & 0,5 \mu \mathrm{l} \\ \mathrm{MgCl}_{2} & 1,5 \mu \mathrm{l} \\ \text { DNA (30ng) } & 1 \mu \mathrm{l} \\ \text { Taq (DS-Bio) } & 0,12 \mu \mathrm{l} \\ \mathrm{H}_{2} \mathrm{O} & 19,28 \mu \mathrm{l}\end{array}$

El programa utilizado fue el siguiente:

$>1$ ciclo de 2 min a $95^{\circ} \mathrm{C}$

$>30$ ciclos de $30 \mathrm{~s}$ a $95^{\circ} \mathrm{C}, 30 \mathrm{~s}$ a $58^{\circ} \mathrm{C}$ y $1 \mathrm{~min}$ a $72^{\circ} \mathrm{C}$

$>1$ ciclo de 5 min a $72^{\circ} \mathrm{C}$

Finalizada la PCR, $10 \mu \mathrm{l}$ del producto se analizaron por electroforesis en geles de agarosa 1,5\% con el marcador de peso molecular 100 bp DNA Ladder (Fermentas). Con el volumen restante se realizó una digestión enzimática con EcoRI. El sitio de corte de esta enzima no se encuentra presente en el fragmento amplificado del vector vacío, y si está presente en la secuencia diseñada del shRNA. Por lo tanto, si el fragmento amplificado tiene la secuencia de clonado introducida es capaz de ser digerido con EcoRI, mientras que si no se introdujo el inserto, el fragmento no se corta con la enzima. 
Se digirieron $4 \mu \mathrm{l}$ del producto de PCR, agregando $1,5 \mu \mathrm{l}$ de buffer, $1 \mu \mathrm{l}$ de enzima y 8,5 $\mu \mathrm{l} \mathrm{de} \mathrm{H}_{2} \mathrm{O}$. Como control sin digerir se mezclaron $4 \mathrm{ul}$ del producto de PCR con $11 \mu \mathrm{lde} \mathrm{H}_{2} \mathrm{O}$, sin agregado de enzima. La reacción se llevó a $37^{\circ} \mathrm{C}$ por $1 \mathrm{~h}$. Los productos se corrieron en un gel de agarosa $2 \%$.

\subsubsection{Digestión enzimática del plásmido recombinante}

Se realizó también una digestión directa del plásmido con EcoRI. Se obtuvieron pequeñas cantidades de plásmido recombinante por miniprep (descripta en 2.5.3) y se digirieron $500 \mathrm{ng}$ del producto con $1 \mu \mathrm{l}$ de EcoRI y 1,5 $\mu \mathrm{l}$ de buffer. La reacción se llevó a $37^{\circ} \mathrm{C}$ por $1 \mathrm{~h}$. Los productos se corrieron en un gel de agarosa $2 \%$.

\subsubsection{Secuenciación.}

Como último paso para analizar el plásmido obtenido luego del proceso de clonado, y verificar que el inserto está correctamente incluido en el vector pPPT, se secuenciaron las muestras. La secuenciación fue encargada a la empresa Macrogen, que utiliza el método de secuenciación a gran escala desarrollado por Applied Biosystems, concretamente el modelo 3730XL. Las muestras se enviaron en una concentración de $100 \mathrm{ng} / \mu \mathrm{l}$ y un volumen mínimo de $20 \mu \mathrm{l}$.

\section{PRODUCCIÓN DE LENTIVIRUS.}

Se trabajó con lentivirus de tercera generación, compuesto por 4 vectores: el vector de transferencia que porta el shRNA, y los vectores de empaquetamiento RRE, REV y VSV-G. La línea celular utilizada para la producción de partículas virales fue HEK 293T.

\subsection{Producción de lentivirus por transfección de HEK 293T.}

El proceso de transfección implica la introducción de DNA exógeno a una célula eucariota. En el presente trabajo, las partículas virales fueron obtenidas por co-transfección de células HEK 293 con los cuatro plásmidos diferentes. La transfección fue llevada a cabo por medio del método del fosfato de calcio [80]. Se prepararon los siguientes tubos:

$\begin{array}{ll}\text { Tubo1 } & \text { Tubo2 } \\ 10 \mu \mathrm{g} \text { RRE } & 840 \mu \mathrm{l} \text { HEPES } \\ 5 \mu \mathrm{g} \text { REV } & \\ 5 \mu \mathrm{g} \text { VSV-G } & \\ 20 \mu \mathrm{g} \mathrm{shRNA-EGFR/SCR} & \\ 84 \mu \mathrm{l} \mathrm{CaCl} 2 & \\ 740 \mu \mathrm{H} \mathrm{H}_{2} \mathrm{O} & \end{array}$

Una vez preparados los 2 tubos, se tomó con pipeta todo el contenido del tubo 1 y se lo agregó al tubo 2, gota a gota para que las soluciones se vayan mezclando bien. Se incubó la mezcla por $15 \mathrm{~min}$ a temperatura ambiente, y luego se la transfirió, también gota a gota, a las placas de cultivo de 100 mm con las células (que se encontraban en un $30-40 \%$ de confluencia). El medio de cultivo, que 
contiene las partículas virales (l-shEGFR y l-shSCR), fue recolectado a las 24, 48 y 72 hs luego de la transfección, y centrifugado por 10 min y 3.000 rpm para descartar los restos celulares.

\subsection{Concentración del lentivirus obtenido.}

El sobrenadante obtenido del cultivo fue concentrado por dos métodos diferentes. En primera instancia se concentró por ultracentrifugación. Para ello se utilizó una ultracentrífuga Beckman Coulter LE-80K, y se centrifugaron los virus por 2,5 hs a $21.000 \mathrm{rpm} \mathrm{y} 4^{\circ} \mathrm{C}$. Se descartó el sobrenadante y el precipitado viral fue resuspendido en cantidades variables (150-500 $\mu$ l por tubo) de PBS estéril durante toda la noche a $4^{\circ} \mathrm{C}$. Luego el virus fue fraccionado en alícuotas y conservado a $-80^{\circ} \mathrm{C}$.

Se utilizó un protocolo alternativo, que no implica el uso de ultracentrífuga. El sobrenadante viral se centrifugó en una Sorvall RC-5B por 4 hs a $10.000 \mathrm{rpm} \mathrm{y} 4^{\circ} \mathrm{C}$, utilizando un colchón de sacarosa al $10 \%$ en PBS estéril. Se descartó con cuidado el sobrenadante y se resuspendió el precipitado en $1 \mathrm{ml}$ de PBS estéril durante toda la noche a $4^{\circ} \mathrm{C}$. Luego el virus fue fraccionado en alícuotas y conservado a $-80^{\circ} \mathrm{C}$.

\subsection{Titulación del virus.}

Una vez obtenidas las partículas virales se calcularon las unidades de transducción por ml (TU/ml). Para ello se utilizaron células HEK 293T, que fueron transducidas con diluciones seriadas del stock lentiviral. Se dispusieron para cada virus 6 tubos con $100 \mu \mathrm{l}$ de DMEM, y se agregó al primero de la serie $10 \mu \mathrm{l}$ de virus. Luego se tomaron $10 \mu \mathrm{l}$ del primer tubo y se pasaron al segundo, y así sucesivamente hasta llegar al último, generando diluciones seriadas $1 / 10$. A cada tubo se agregaron $20 \mu \mathrm{l}$ de polybrene $(8 \mu \mathrm{g} / \mathrm{mL}$, Sigma), y a continuación se agregaron los $120 \mu \mathrm{l}$ finales de cada tubo a cada pocillo de una placa de 6 pocillos de células. Al cabo de 72 hs se contó el número de células fluorescentes rojas en un microscopio invertido Olympus IX71, usando un objetivo de 20X. La fluorescencia de emisión fue detectada usando el filtro de $575 \mathrm{~nm}$ para DsRed y se refirió al volumen de virus colocado y al factor de dilución en cada placa, obteniendo el título en TU/ml.

\section{EXPERIMENTOS DE SILENCIAMIENTO in vitro.}

\subsection{Expresión del EGFR de rata en células HEK 293T.}

Dado que las células HEK 293T derivan de tejido humano, y el shRNA diseñado es específico para el EGFR de rata, para realizar experimentos de silenciamiento en este sistema lo primero que se hizo fue expresar el EGFR de rata en las HEK 293T. Para ello se transfectaron placas de $35 \mathrm{~mm}$ de células, mediante la técnica de fosfato de calcio ya descripta en "3.1", con un plásmido que expresa el EGFR de rata acoplado a la proteína fluorescente verde (GFP del inglés 
Green fluorescent protein), generosamente cedido por el Dr. Jeffrey E. Segall del Albert Einstein College of Medicine de Nueva York [81]. Se realizaron curvas de expresión transfectando con 0, 2 y $4 \mu \mathrm{g}$ de plásmido, y compensando la cantidad de DNA en cada transfección con un plásmido vacío (4, 2 y $0 \mu \mathrm{g}$ respectivamente). A las 72 hs de la transfección se observaron las células con un microscopio invertido Olympus IX71, usando el filtro de $510 \mathrm{~nm}$ para GFP. También se realizó Western blot (será detallado en "5.6"), para lo cual se lavaron las placas de cultivo con células con 2 $\mathrm{ml}$ de PBS estéril lavando y se lisaron las células por adición de $150 \mu \mathrm{l}$ de buffer de corrida SDSPAGE. Previo a la corrida, las muestras fueron procesadas con una jeringa calibre 26 (Becton Dickinson), lo cual permite una degradación mecánica del material celular, así como también del DNA presente.

\subsection{Curvas de silenciamiento.}

Se utilizaron placas de $35 \mathrm{~mm}$, y se co-transfectaron los cultivos con $500 \mathrm{ng}$ del plásmido que codifica para EGFR-GFP y cantidades crecientes del plásmido shRNA-EGFR $(0,0,5,1,2$ y 4 $\mu \mathrm{g})$. Nuevamente la cantidad total de DNA se niveló en todos los pocillos usando un vector vacío. A las 72 hs de la transfección se observaron las células con un microscopio invertido Olympus IX71, usando los filtros de $510 \mathrm{~nm}$ para GFP y $575 \mathrm{~nm}$ para DsRed. También se realizó Western blot, preparando las muestras como se describió en "4.1.1".

\section{EXPERIMENTOS DE SILENCIAMIENTO in vivo.}

\subsection{Infusión de Ang II para generar HC.}

Se utilizaron mini-bombas osmóticas Alzet modelo 2004 implantadas en un bolsillo en el tejido celular subcutáneo del espacio interescapular. Estás bombas garantizan la administración continua de su contenido durante 28 días a un flujo de $0,25 \mu \mathrm{L} / \mathrm{h}$. La colocación se hizo en ratas Wistar macho de 4 meses, bajo anestesia leve (ketamina 80mg/kg-diazepam $5 \mathrm{mg} / \mathrm{kg}$ i.p.). Se rasuró la zona medio escapular, se realizó una incisión para crear un bolsillo subcutáneo donde se colocó la bomba y se suturó la piel. Las bombas se cargaron con una dosis de 200 ng/Kg/día de Ang II.

\subsection{Inyección intramiocárdica del lentivirus .}

Los animales fueron anestesiados con sevofluorano (4\% para inducción y 2-3\% para mantenimiento), usado en una mezcla gaseosa con oxígeno y aplicado a través de ventilación usando un respirador (Model 680, Harvard, South Natick, Massachusetts). Luego de alcanzada una anestesia profunda, se les realizó una toracotomía a través del cuarto espacio intercostal, retrayendo los pulmones para exponer el corazón. El lentivirus correspondiente fue inyectado en dos sitios de la pared anterolateral del ventrículo izquierdo, cerca de ápex cardíaco, usando una aguja de 30G $[82,83]$. Inmediatamente después de la cirugía las ratas fueron retornadas a sus cajas 
y llevadas a la sala de recuperación. Se mantuvieron en el bioterio hasta su sacrificio, 1 mes después de la cirugía.

\subsection{Ecocardiografía.}

Las ratas fueron monitoreadas por ecocardiografía al inicio y al final de cada protocolo, bajo anestesia ligera con sevofluorano al $4 \%$, a través de un ecocardiógrafo utilizando un transductor de $7,5 \mathrm{mHz}$ (ATL 3500). Se obtuvieron imágenes bidimensionales de planos equivalentes al eje corto paraesternal en humanos, a partir de las cuales y seleccionando las de mejor resolución, se realizó un registro en modo $M$ a velocidad de barrido de $50 \mathrm{~mm} / \mathrm{seg}$. Las imágenes congeladas en modo $\mathrm{M}$ se digitalizaron para realizar las determinaciones off-line. Las medidas fueron realizadas de acuerdo a los métodos de la Sociedad Americana de Ecocardiografía [84].

El período de eyección del ventrículo izquierdo se midió en el registro de flujo de la válvula aórtica. De cada registro se tomaron los siguientes parámetros (Figura 13A): diámetro diastólico del ventrículo izquierdo (DDVI), diámetro sistólico del ventrículo izquierdo (DSVI), séptum interventricular en diástole (SD), séptum interventricular en sístole (SS), espesor en diástole de la pared posterior del ventrículo izquierdo (PPd) y espesor sistólico de la pared posterior del ventrículo izquierdo (PPs). A partir de estas medidas se calcularon el espesor parietal relativo $(\mathrm{h} / \mathrm{r})$, la masa ventricular izquierda (MVI), el acortamiento endocárdico y el acortamiento medio ventricular (Figura 13B).

A.

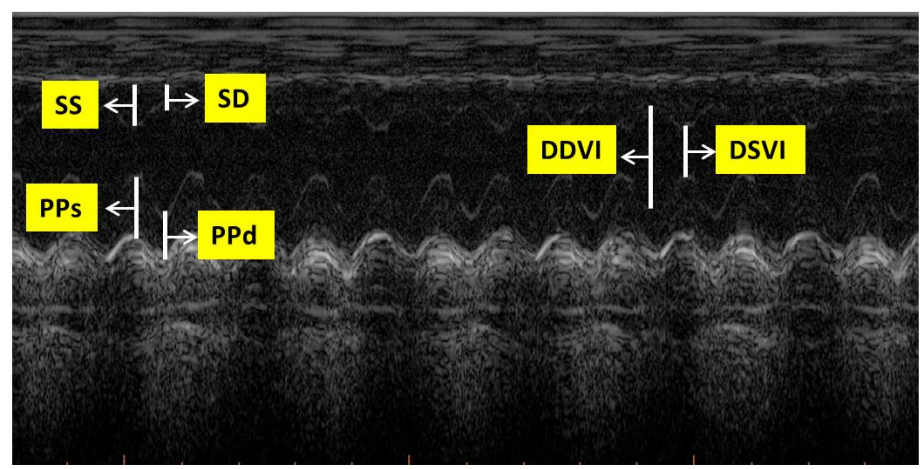

B.

$$
M V I(m g)=1,04 \times\left[(D D V I+P P d+S D)^{3}-(D D V I)^{3}\right]
$$

$$
\begin{gathered}
\text { Acortamiento } \\
\text { Endocárdico }(\%)
\end{gathered}=\frac{\mathrm{DDVI}-\mathrm{DDVS}}{\mathrm{DDVI}} \times 100 \quad \mathrm{~h} / \mathrm{r}=\frac{\mathrm{PPd} \times 2}{\mathrm{DDVI}}
$$

$\begin{gathered}\text { Acortamiento } \\ \text { medio ventricular }(\%)\end{gathered}=\left(\frac{(\mathrm{DDV} I+\mathrm{SD} / 2+\mathrm{PPd} / 2)-(\mathrm{DSVI}+(\mathrm{SS}+\mathrm{PPS}) / 2)}{(\mathrm{DDVI}+\mathrm{SD} / 2+\mathrm{PPd} / 2)}\right) \times 100$

Figura 13. A. Imagen ecocardiográfica modelo con los parámetros medidos indicados. B. Fórmulas uitilizadas para calcular el MVI, el acortamiento endocárdico, el h/r y el acortamiento medio ventricular a partir de las mediciones. 


\subsection{Determinación de la presión arterial.}

Se realizaron dos registros semanales de presión arterial de los animales con implantación de bomba de Ang II y SHR durante el mes de tratamiento con el lentivirus. Para la medida se utilizó el método indirecto de la cola [85].

\subsection{Determinación de área de miocitos y colágeno.}

El tejido del VI fue fijado en formaldehído al 10\% y embebido en parafina. Las secciones del corazón a nivel del VI (4 $\mu \mathrm{m}$ de espesor) se tiñeron con hematoxilina-eosina para determinar el área de sección transversal de los cardiomiocitos (STC) o con la técnica de picrosirius para cuantificar la fracción volumétrica del colágeno [86]. Todas las secciones teñidas se observaron en el microscopio (Olympus BX-50, Tokio,Japón). Las imágenes fueron capturadas usando una cámara digital, y procesadas con un programa de morfometría (Image-Pro Plus, Media Cybernetics, Silver Spring, MA). La STC se determinó en 50 células de cada animal, seleccionadas aleatoriamente. Sólo fueron considerados aquellas cardiomiocitos que mostraran un núcleo evidente en la sección transversal. La fracción de volumen de colágeno se calculó como la suma de todas las áreas de tejido conectivo de las secciones, divididas por la superficie total de la sección. El colágeno perivascular fue excluido de esta medida.

\subsection{Estudios de funcionalidad en papilares aislados.}

\subsubsection{Aislamiento de músculos papilares y determinación de fuerza contráctil.}

Se utilizaron músculos papilares del ventrículo izquierdo de los animales inyectados con 1shEGFR y 1-shSCR para evaluar la SFF al estiramiento, siguiendo un método descripto previamente [87]. Los músculos fueron montados en una cámara de perfusión horizontal entre un transductor de fuerza y un soporte fijo para obtener contracciones isométricas, y perfundidos con solución Ringer. La posible participación de catecolaminas liberadas por las terminaciones nerviosas fue prevenida con el agregado de bloqueantes de receptores adrenérgicos $(1.0 \mu \mathrm{mol} / \mathrm{L}$ prazosin más $1.0 \mu \mathrm{mol} / \mathrm{L}$ atenolol). Los músculos fueron estimulados eléctricamente mediante pulsos cuadrados con un voltaje $10 \%$ por encima del umbral de estimulación a una frecuencia de $0,2 \mathrm{~Hz}, \mathrm{y}$ mantenidos a $30^{\circ} \mathrm{C}$. El área de la sección transversal de los músculos papilares (calculada como 0,75 del producto del ancho por el espesor) fue usada para normalizar los registros de fuerza obtenidos mediante un "silicon strain gauge" (modelo AEM 801, Kronex Technologies Corp, Oakland, CA, USA). Se determinó la longitud inicial de cada músculo ("slack length") inmediatamente después de montados, para luego ser estirados progresivamente hasta la longitud a la cual desarrollaban la máxima fuerza contráctil (Lmax). Una vez alcanzada Lmax fueron desestirados hasta obtener el 95\% de la fuerza máxima, longitud que se aproxima al 98\% de Lmax y que se denomina L98, para finalmente ser desestirados hasta el 92\% de Lmax (L92), longitud a la cual fueron mantenidos hasta el inicio del protocolo de estiramiento para determinar la SFF. El 
protocolo experimental para evaluar la SFF consistió en un estiramiento abrupto de L92 a L98 con un seguimiento de $10 \mathrm{~min}$.

\subsubsection{Determinación de $\mathrm{pH}$ intracelular $\left(\mathrm{pH}_{\mathrm{i}}\right)$.}

Para la determinación del $\mathrm{pHi}$ se utilizó una técnica de epifluorescencia con el indicador de pH BCECF-AM [87]. Para ello, se montaron músculos papilares en una cámara de perfusión horizontal similar a la descripta en el apartado anterior, pero en este caso posicionada sobre la platina de un microscopio invertido (Olympus CK2) adaptado para la determinación de iones intracelulares por fluorescencia. Luego de registrados los niveles de autofluorescencia, los músculos fueron incubados por $1 \mathrm{~h}$ con una solución que contiene BCECF-AM. Al final del período de carga, se lavó el espacio extracellular con una solución libre del colorante por 30-60 min, antes de cualquier determinación de $\mathrm{pH}_{\mathrm{i}}$. Para limitar la degradación de la señal por efecto de la luz excitatoria, un filtro de densidad neutra ( $1 \%$ de la transmitancia) fue puesto en el camino de la luz excitatoria. Se utilizó un obturador manual para seleccionar de modo alternativo los distintos filtros de excitación (440-495 nm). El protocolo experimental usado consistió en monitorear los cambios de $\mathrm{pH}$ mediados por el NHE1 luego de la aplicación de una única dosis de Ang II ( $1 \mathrm{nmol} / \mathrm{L})$ en músculos de los corazones tratados y controles. Para asegurar que el único mecanismo activo de regulación del $\mathrm{pH}_{\mathrm{i}}$ era el NHE1 los experimentos fueron realizados en ausencia nominal de bicarbonato (buffer HEPES). Al final de cada experimento la emisión de fluorescencia fue calibrada con el método de alto $\mathrm{KCl} /$ nigericina [87], para transformar los cocientes de fluorescencia experimental en valores de $\mathrm{pH}_{\mathrm{i}}$.

\subsubsection{Determinación de la actividad del NHE1 por pulso de amonio.}

Otro modo de medir actividad del NHE1 fue evaluar la recuperación- $\mathrm{Na}^{+}$dependiente de $\mathrm{pH}_{\mathrm{i}}$ desde una carga ácida aguda inducida por un pre-pulso de amonio $\left(\mathrm{NH}_{4} \mathrm{Cl}\right)$ [88]. $\mathrm{Al}$ agregar $\mathrm{NH}_{4}{ }^{+}$al medio externo se produce una alcalinización intracelular de carácter transitorio debido a la migración del $\mathrm{NH}_{3}$ a través de la membrana y su posterior reconversión a $\mathrm{NH}_{4}{ }^{+} \mathrm{y} \mathrm{OH}^{-}$. Cuando se lava el amonio del medio extracelular, el $\mathrm{NH}_{3}$ sale del interior de la célula por gradiente y los $\mathrm{H}^{+}$ introducidos quedan retenidos en el interior celular generando una acidificación, cuya recuperación depende del NHE1 al trabajar en ausencia nominal de bicarbonato. La acidificación se realizó exponiendo los músculos por $10 \mathrm{~min}$ a $30 \mathrm{mmol} / \mathrm{L}$ de $\mathrm{NH}_{4} \mathrm{Cl}$, y lavando del amonio con buffer HEPES conteniendo $\mathrm{Na}^{+}$. El monitoreo y registro de fluorescencia tras el agregado de $\mathrm{Na}^{+}$se realizó durante $30 \mathrm{~min}$.

\subsubsection{Determinación de la rigidez miocárdica.}

Se evaluó la rigidez miocárdica en papilares aislados de VI mediante curvas longitudtensión. Los experimentos se realizaron en solución Ringer. Al cabo de un tiempo de estabilización se determinó longitud inicial (Lslack), el ancho y el espesor de cada músculo. Luego se los estiró progresivamente en intervalos de 10\% del Lslack hasta alcanzar su Lmáx, registrándose a cada paso la fuerza isométrica, la cual fue normalizada por la superficie de sección transversal (SST) de los papilares, calculada como "ancho x espesor x 0.75 ". Los datos experimentales de tensión de reposo fueron expresados en porciento de la tensión medida a Lmáx y ajustados a una función 
exponencial para luego promediar valores a porcentajes fijos de tensión.

\subsection{Evaluación de estrés oxidativo.}

\subsubsection{Medición de la producción de anión superóxido $\left(\mathrm{O}_{2} \cdot{ }^{*}\right)$.}

Se trabajó con tiras de corazón del ventrículo izquierdo $(1 \times 5 \mathrm{~mm})$, y se utilizó el método de quimioluminiscencia aumentada por lucigenina [89]. Las tiras de corazón fueron incubadas en buffer de lucigenina en ausencia o presencia de Ang II $(1 \mathrm{nmol} / \mathrm{L})$ y EGF $(0,1 \mu \mathrm{g} / \mathrm{mL})$, durante 30 min en un incubador a $37^{\circ} \mathrm{C}$ con $95 \% \mathrm{O}_{2}-5 \% \mathrm{CO}_{2}$. La quimioluminiscencia en unidades arbitrarias fue registrada con un luminómetro (Chameleon; Hidex; Finland) durante $30 \mathrm{~s}$ cada 4,5 min por un período total de $30 \mathrm{~min}$. La producción de $\mathrm{O}_{2}{ }^{\cdot}$ fue normalizada por $\mathrm{mg}$ de tejido seco y expresada por min.

\subsubsection{Peroxidación lipídica.}

La peroxidación lipídica fue determinada midiendo la tasa de producción de sustancias reactivas al ácido tiobarbitúrico (TBARS), expresada en nmol/mg de tejido. Homogenatos de corazón fueron centrifugados a $2.000 \mathrm{rpm}$ por $10 \mathrm{~min}$. $0,5 \mathrm{ml}$ del sobrenadante se mezcló con 1,5 ml de ácido tricloroacético $(30 \% \mathrm{p} / \mathrm{v}), 1 \mathrm{ml}$ de ácido tiobarbitúrico $(0,7 \%$ p/v) y 0,5 $\mathrm{ml}$ de agua, luego de lo cual se hirvió la mezcla por $15 \mathrm{~min}$. Luego de enfriar las muestras, se midió la absorbancia a $535 \mathrm{~nm}$.

\subsubsection{Actividad de NADPH oxidasa (NOX).}

Se midió la producción de superóxido dependiente de NOX en homogenatos de ventrículo izquierdo de ratas de ambos grupos experimentales, usando quimioluminiscencia por lucigenina [62]. Las proteínas fueron diluídas en buffer HEPES y distribuidas (100 $\mu 1 /$ pocillo) en una microplaca de 96 pocillos. Se agregó NADPH $(100 \mu \mathrm{mol} / \mathrm{L})$ a los pocillos y se efectuó la lectura con el luminómetro, durante $15 \mathrm{~min}$. La actividad de NOX medida por producción de $\mathrm{O} 2^{\circ}$ fue expresada en cpm/mg de proteína.

\subsection{Western blot.}

Las muestras de tejido fueron preparadas a partir del ventrículo izquierdo de los animales sacrificados un mes después de la inyección del lentivirus. El tejido cardíaco fue homogeneizado en buffer de lisis RIPA (sc-24948), suplementado con un cóctel de inhibidores de proteasas (sc24948), ortovanadato de sodio (sc-24948) y PMSF (sc-24948). Se centrifugó el homogenato a 13.000 rpm por $10 \mathrm{~min}$ a $4^{\circ} \mathrm{C}$, y se fraccionó el sobrenadante en alícuotas para conservarlo a $-80^{\circ} \mathrm{C}$. La concentración de proteínas fue determinada por el método de Bradford [90]. Para la corrida electroforética, $30 \mu \mathrm{g}$ de proteína fueron mezclados con buffer de corrida SDS-PAGE.

Las muestras fueron corridas en geles de acrilamida al 10\%. Se realizaron 30 min iniciales a 
$65 \mathrm{mV}$, para apilar las proteínas en el frente de corrida, y luego se corrió a $100 \mathrm{mV}$. Las proteínas fueron transferidas a membranas de PVDF por electroforesis por 1,5 hs a $70 \mathrm{mV}$ a temperatura ambiente, en un buffer de transferencia. Las membranas fueron luego bloqueadas por incubación por 2 hs en solución de bloqueo, e incubadas toda la noche con los anticuerpos primarios correspondientes (ver Anexo 2). A continuación se usaron anticuerpos secundarios (ver Anexo 2), conjugados con una peroxidasa. Las bandas se visualizaron con un reactivo de luminiscencia (ECL, Millipore) y el equipo Chemidoc Station (Bio-Rad), y se cuantificaron con el software de análisis Image J.

\subsection{Microscopía confocal.}

Muestras de ventrículo izquierdo fueron extraídas en formalina durante 24 hs, y luego cortadas de manera serial en secciones de $10 \mu \mathrm{m}$ de grosor usando un vibrátomo (Leica VT 1000S). La fluorescencia se detectó usando un microscopio confocal (Olympus FV1000). Se usó un láser de $559 \mathrm{~nm}$ para excitar el fluoróforo DsRed, y el objetivo 4X para determinar la distribución viral en el tejido. Para la captura de imágenes, la intensidad del láser de $559 \mathrm{~nm}$ y la de su fotomultiplicador se mantuvieron constantes a fin de comparar cualitativamente las muestras.

\subsection{Estadística.}

Los datos fueron expresados como media \pm error estándar. Para comparar grupos de valores con $n>4$ se utilizó test de Student o ANOVA de una vía, según el caso. Se utilizó ANOVA para mediciones repetidas para comparar los valores de fuerza post estiramiento y los de $\mathrm{pH}_{\mathrm{i}}$ post Ang II obtenidos a los distintos tiempos experimentales (para cada grupo experimental) versus sus correspondientes controles a tiempo cero (previo a cada intervención). Se usó ANOVA de dos vías para comparar las curvas de fuerza post estiramiento y de $\mathrm{pHi}$ post Ang II entre los distintos grupos experimentales. Un valor de $\mathrm{p}<0,05$ fue considerado estadísticamente significativo. Cuando los grupos de valores tuvieron un $n \leqslant 4$ se los analizó por test estadísticos no paramétricos, Mann-Whitney o Krustal-Wallis según correspondía. 
RESULTADOS 


\section{SECCIÓN I: CLONADO MOLECULAR Y SILENCIAMIENTO in vitro.}

\section{CLONADO DEL ShRNA.}

La secuencia del RNAi contra el EGFR se obtuvo de bibliografía, mientras que el RNAi SCR se diseñó mediante un programa de computación (ver punto "2.1" de la Sección Materiales y Métodos). Previo al diseño de los cassettes de expresión de los shRNAs completos y al inicio del proceso de clonado, se analizaron ambas secuencias mediante el programa BLAST (NCBI), un primer paso siempre necesario en el inicio de todo protocolo de clonado. Pese a que la secuencia del RNAi del EGFR proviene de una publicación, el control de su especificidad es igualmente necesario, tanto para el aprendizaje del manejo del programa como para verificar el alineamiento con el genoma de rata; en el caso de la secuencia del RNAi del SCR, la necesidad del paso de control es aún mayor dado que surgió del diseño computacional y nunca había sido alineada con el genoma del animal de estudio en el presente trabajo. Efectivamente la secuencia elegida para silenciar el EGFR tiene un alineamiento significativo con el receptor de rata, y presenta un "Evalue" de 0,001, que expresa la posibilidad de un alineamiento no específico. Por lo tanto, la secuencia con la que se construyó el shRNA-EGFR es específica para esa proteína en el genoma de la rata. El mismo análisis se realizó para la secuencia SCR, obteniéndose valores de "E-value" iguales o mayores a 16, lo que indica que es posible que se produzcan alineamientos parciales no específicos, pero la secuencia no inhibirá ningún elemento del genoma de la rata de forma específica, que es lo que se busca para una secuencia a utilizarse como control.

EGFR sentido

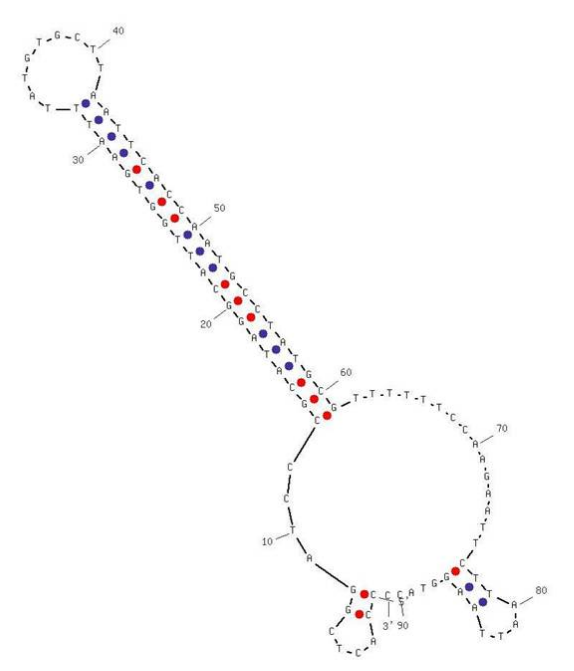

- $\Delta \mathrm{G}$ hairpin $=-22,88 \mathrm{kcal} / \mathrm{mol}$

- $\Delta \mathrm{G}$ homodímero $=-39,58 \mathrm{kcal} / \mathrm{mol}$

- $\Delta \mathrm{G}$ heterodímero $=-177,28 \mathrm{kcal} / \mathrm{mol}$

\section{SCR sentido}

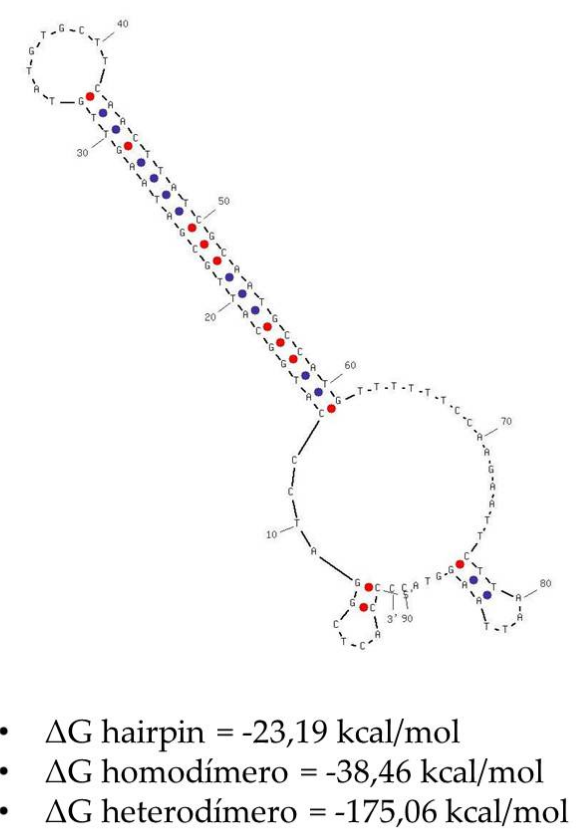

Figura 14. Formación del inserto doble cadena. 
A continuación se diseñaron los cassettes de expresión de los shRNA correspondientes agregando los elementos detallados en el punto “2.1" de la Sección Materiales y Métodos, y se analizaron las secuencias completas del shRNA-EGFR y shRNA-SCR mediante el programa OligoAnalyzer, a fin de simular in silico la formación del hairpin. En la Figura 14 pueden observarse las estructuras predichas, que forman dímeros doble cadena con un loop que serán reconocidos por la maquinaria intracelular del $\mathrm{RNi}$.

Con el mismo programa se analizaron los valores de energía libre $(\Delta G)$ correspondientes a la formación del hairpin, de los homodímeros (hibridización de 2 cadenas sentido o 2 anti sentido) y de los heterodímeros (hibridización de una cadena sentido con una anti sentido), a fin de evaluar si la formación del inserto doble cadena necesario para clonar en el vector de transferencia es posible. Los resultados, indicados en la Figura 14 demuestran que la formación del DNA doble cadena es termodinámicamente más favorable que la formación del hairpin, y a su vez que dentro de las moléculas doble cadena, es mucho más favorable la formación del heterodímero (que es la molécula necesaria para el clonado posterior) que la del homodímero.

El primer paso implicado en la construcción del vector de transferencia portador de los shRNA diseñados fue la formación del inserto doble cadena, por "annealing" o apareamiento entre los primers sentido y anti sentido. Se siguió el protocolo detallado en el apartado "2.2.1" de la sección Materiales y Métodos, y los productos de la reacción se corrieron en un gel de agarosa $4 \%$. La Figura 15 muestra los resultados para la secuencia del shRNA-EGFR, donde puede observarse que tanto las moléculas simple cadena como el dímero doble cadena (91 pb) caen en el peso esperado.

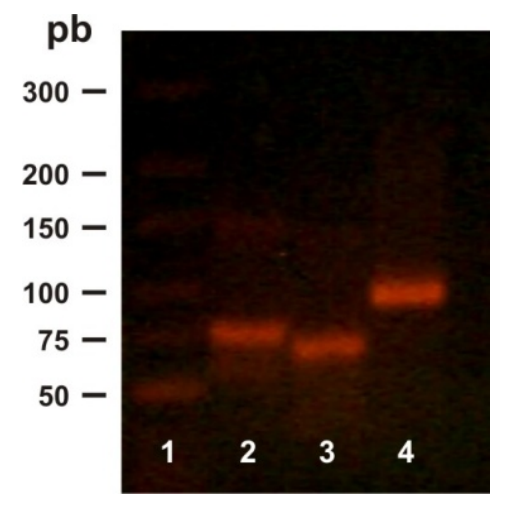

Figura 15. Formación del inserto doble cadena. 1. GeneRulerTM Ultra Low Range DNA Ladder. 2. EGFR sentido. 3. EGFR antisentido. 4. EGFR doble cadena.

Una vez generado el inserto doble cadena, se procedió a realizar la digestión enzimática tanto del inserto como del vector. En el caso del vector, inicialmente se cortó con BamHI (Figura 16A) dado que en experimentos previos se observó que esta enzima producía un corte incompleto y la electroforesis en gel de agarosa permite separar el vector pPPT cortado de aquel que no lo está, mientras que PacI produce un corte total. Las bandas superiores corresponden al vector cortado, que al haberse linearizado corre menos en los geles de agarosa y aparece a un peso molecular superior. Las bandas inferiores corresponden al vector que quedó sin cortar que, al ser superenrrollado y por lo tanto más compacto, tiene una mayor movilidad electroforética. Para 
continuar con el clonado, se extrajeron y purificaron las bandas superiores.

A continuación, se cortó el vector pPPT con PacI (Figura 16B). Este segundo corte no tiene un resultado visible en geles de agarosa, dado que el fragmento que se elimina al cortar con la segunda enzima es de apenas $68 \mathrm{pb}$, contra los $7.500 \mathrm{pb}$ que tiene el vector pPPT lineal. Por lo tanto, el resultado del corte con PacI es una única banda.

A

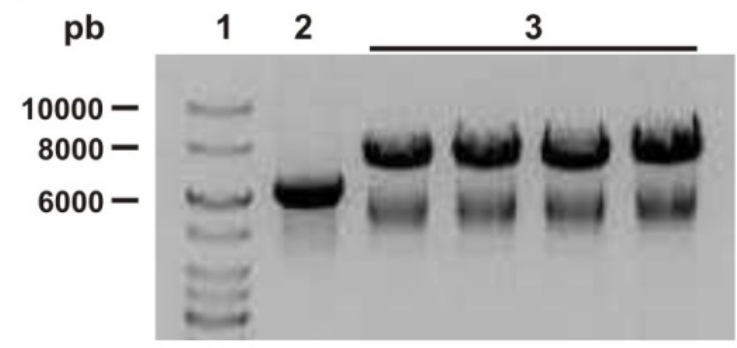

B

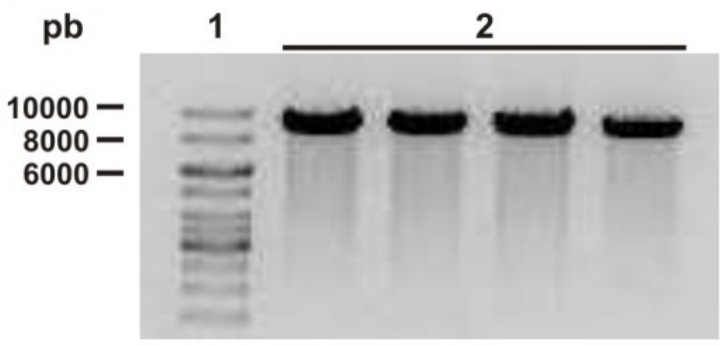

Figura 16. Digestión del vector. A. Vector pPPT digerido con BamHI; 1. Marcador de paso molecular $1 \mathrm{~Kb}$ DNA Ladder. 2. pPPT sin cortar. 3. pPPT cortado con BamHI. B. Vector pPPT digerido con PacI; 1. Marcador de paso molecular 1Kb DNA Ladder. 2. pPPT cortado con PacI.

En el caso del inserto, dado su tamaño, no se realizaron corridas electroforéticas de los productos de digestión, ya que no se verían diferencias. Luego de la digestión directamente se purificó el producto mediante el kit.

Obtenidos el vector y el inserto digeridos, se procedió a ligarlos. Las relaciones de ligación vector:inserto utilizadas fueron 1:3, 1:10 y 1:50, y se ligó a temperatura ambiente por $1 \mathrm{~h}$. En todos los casos se utilizó como control positivo el vector pPPT cortado con una sola enzima, y ligado sin inserto, y como control negativo el vector pPPT cortado con las dos enzimas, y ligado sin inserto. Terminada la reacción de ligación, se utilizó el producto para transformar bacterias E. coli DH5- $\alpha$ electrocompetentes, y luego de crecerlas $1 \mathrm{~h}$ a $37^{\circ} \mathrm{C}$ y con agitación, se sembraron $100 \mu \mathrm{l}$ en placas de LB con ampicilina. Se incubó las placas en estufa toda la noche. El control negativo no creció, indicando que el plásmido pPPT cortado con ambas enzimas pero en ausencia de inserto no se religó, aún en presencia de la T4 DNA ligasa. Al no circularizarse se degrada al ingresar a la bacteria, y por lo tanto no le confiere resistencia a ampicilina. El control positivo presentó una gran cantidad de colonias, indicando que la ligación fue efectiva, dado que consistía en el vector pPPT cortado una sola vez, y por tanto con extremos cohesivos compatibles. Las 3 relaciones vector:inserto ensayadas tuvieron crecimiento de colonias.

El paso siguiente fue elegir colonias al azar de todas las placas, y tomarlas para realizar cultivos de $5 \mathrm{ml}$ de LB con ampicilina por 24 hs a $37{ }^{\circ} \mathrm{C}$. A partir de los cultivos crecidos se realizaron minipreps (Figura 17A, se muestran 2 clones representativos para el shRNA-EGFR, se realizó lo mismo para el SCR) para extraer el plásmido. El proceso de rastreo o "screening" consiste en la búsqueda a través de técnicas de biología molecular de los clones con el inserto de interés dentro de todos los plásmidos generados (incluidos cada uno en una colonia), y es un paso necesario en todo protocolo de clonado, para limitar el número de muestras a enviar a secuenciar 
(que siempre es el último paso obligado), y tener un conocimiento previo del éxito de la inserción. A fin de analizar si los plásmidos obtenidos tenían efectivamente el inserto de clonado, se utilizaron los productos de la miniprep como moldes para una PCR con los primers H1F2 y M13. El producto de amplificación, que tiene 900 pb, se corrió en un gel de agarosa 1,5\% junto con una PCR utilizando el vector de clonado original como molde (Figura 17B). A continuación se digirió el producto de PCR con EcoRI, la enzima incluida dentro del cassette del shRNA. Esta digestión, que sólo ocurre si el inserto está clonado dentro del plásmido, genera un fragmento de 149 pb y otro de 751. Los productos de digestión se corrieron en un gel de agarosa $2 \%$ junto con una PCR positiva para EcoRI como control positivo (Figura 17C). En los tres casos se observa la liberación de un fragmento que corresponde al producto de $149 \mathrm{pb}$, indicando que los plásmidos aislados de la miniprep poseen el inserto clonado.

A

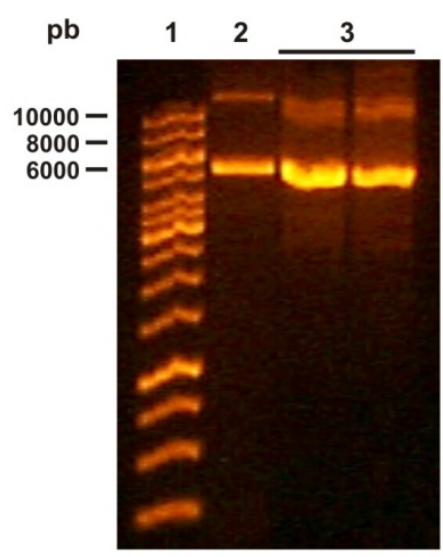

C
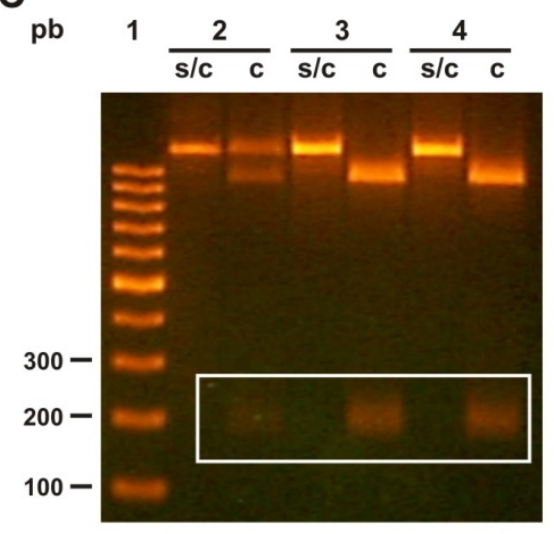

B

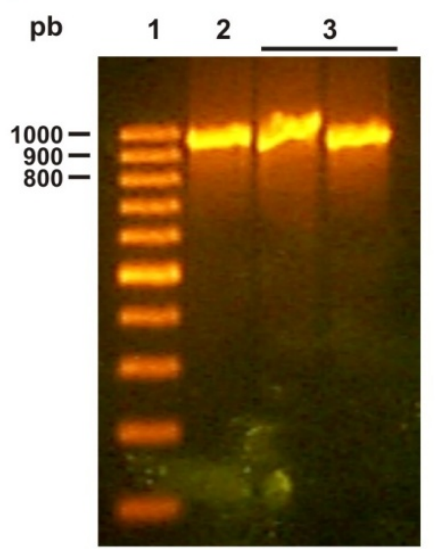

D

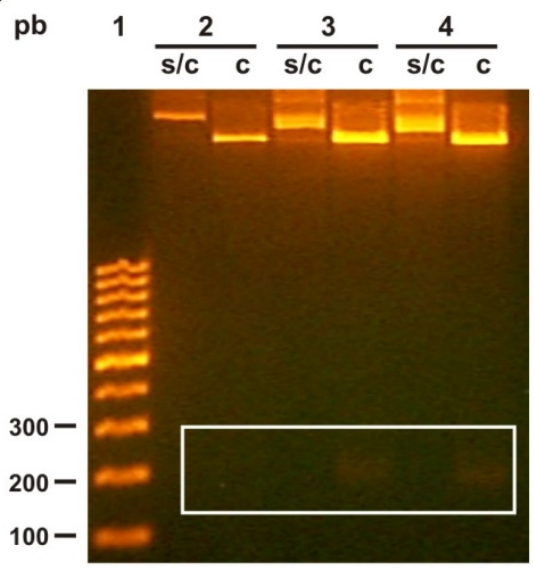

Figura 17. Análisis de plásmido obtenido por clonado. A. Miniprep, 1. $1 \mathrm{~Kb}$ DNA Ladder. 2. pPPT vacío. 3. Dos clones representativos. B. PCR con H1F2 y M13, 1. 100 pb DNA Ladder. 2. pPPT vacío. 3. Clones. C. Digestión del producto de PCR, 1. 100 pb DNA Ladder. 2. Control positivo de digestión con EcoRI. 3 y 4. Clones. D. Digestión del plásmido, 1. 100 pb DNA Ladder. 2. pPPT vacío. 3 y 4. Clones. s/c: sin cortar, c: cortado.

A fin de evaluar si era posible determinar la presencia del inserto sin realizar la PCR, lo que hubiera acortado el proceso de screening, se digirieron el vector de clonado original y los plásmidos obtenidos por miniprep directamente con EcoRI. Si bien no disponemos del mapa completo del vector pPPT, contamos con una porción secuenciada (de 1060 pb), a partir de la cual sabemos que 
la digestión del vector vacío lo vuelve lineal (un sitio de corte para EcoRI en el fragmento secuenciado), mientras que la digestión del vector con inserto, además de volverlo lineal, libera un fragmento de 195 pb (dos sitios de corte para EcoRI, el del vector más el agregado por el inserto). Como puede observarse en la Figura 17D, la digestión de los dos clones mostrados produce la liberación del fragmento de 195 pb (recuadro blanco), mientras que la digestión del vector vacío no. Pese a que esta digestión directa del plásmido permite distinguir si el clonado fue exitoso o no, la realización de la PCR y la posterior digestión del fragmento arrojan un resultado más contundente, y esa fue la estrategia que se utilizó para el análisis del clonado del SCR.

Finalmente, el último paso del protocolo de clonado fue la secuenciación de los plásmidos generados (Macrogen, Korea), a fin de asegurar la correcta inserción del inserto antes de pasar a la producción de virus a partir de dichos plásmidos. Para la secuenciación se utilizaron primers que permitieran una lectura del inserto desde el lado 5' o desde el lado 3' de la secuencia insertada, respectivamente el H1F2 y el T7. Los resultados mostraron la inserción de la secuencia completa de los cassettes de expresión para el shRNA-EGFR y el shRNA-SCR en el vector de clonado, generándose así con éxito los vectores de transferencia para producir los lentivirus correspondientes.

\section{PRODUCCIÓN DE LENTIVIRUS.}

Una vez clonadas las secuencias del shRNA-EGFR y shRNA-SCR en el vector de transferencia, se procedió a producir las partículas lentivirales. Para ello se transfectaron células HEK 293T con los 4 vectores y el éxito de la transfección se corroboró observando las células en el microscopio de fluorescencia, dado que como el vector de transferencia codifica para la proteína fluorescente roja, las células transfectadas se ven rojas (Figura 18A). Se recolectó el medio de cultivo conteniendo los lentivirus durante 72 horas, y luego se procedió a concentrarlos por centrifugación.

Para calcular las partículas virales por unidad de volumen, se utilizaron nuevamente células HEK 293T, esta vez transducidas con diluciones seriadas del virus concentrado. Al infectar el cultivo celular, integra en el genoma de las células el gen de la proteína fluorescente roja, por lo cual a las 72 horas se observaron las placas en el microscopio de fluorescencia (Figura 18B). En todas las diluciones en las que fue posible, se contaron las células fluorescentes, y refiriendo ese número al volumen de virus agregado y la dilución realizada se calculó el título. En cada producción de virus obtuvimos un valor de título diferente, partiendo de $\sim 8 \times 10^{6} \mathrm{TU} / \mathrm{ml}$ en las primeras producciones, y llegando hasta $3 \times 10^{9} \mathrm{TU} / \mathrm{ml}$ en las últimas luego de todas las puestas a punto. 


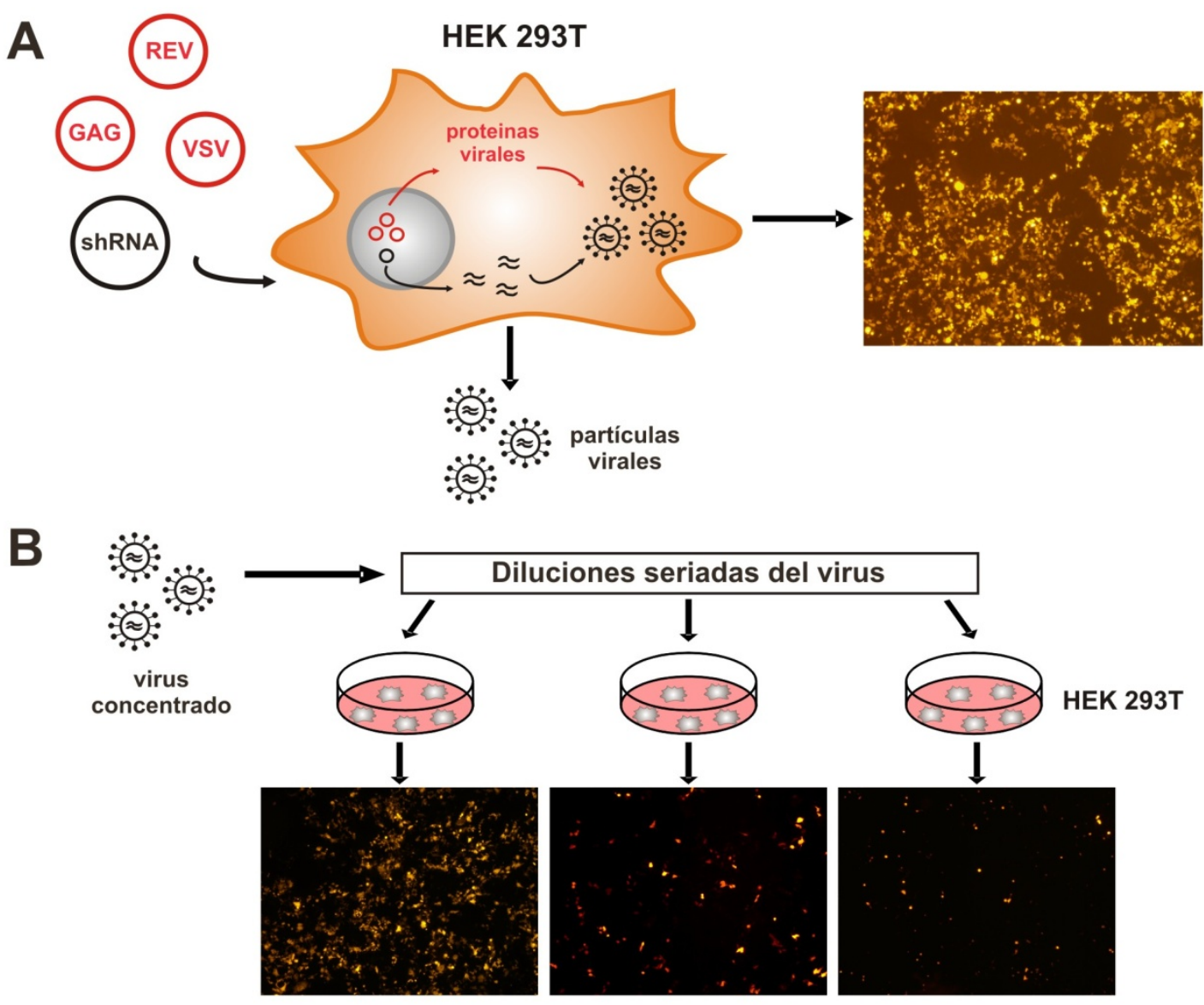

Figura 18. Producción y titulación del virus. A. Esquema de la transfección de células HEK 293T con los vectores virales, e imagen representativa de un cultivo transfectado, 20X. B. Esquema de la titulación, con fotos representativas de 3 diluciones distintas, 20X.

\section{EXPERIMENTOS DE SILENCIAMIENTO in vitro.}

\section{$\checkmark$ Expresión del EGFR de rata en células HEK 293T.}

Luego de clonar el shRNA-EGFR en el vector de transferencia, se probó su capacidad silenciadora en células HEK 293T. Esta línea celular presenta numerosas ventajas, siendo las principales que son fáciles de cultivar y de transfectar. Tanto los miocitos adultos como la línea celular H9c2 (derivada de miocitos) son mucho más laboriosos y costosos de cultivar, y la transfección con fosfato de calcio, de sencilla realización en HEK 293T, es muy dificultosa.

Como las HEK 293T provienen del humano, y la secuencia silenciadora utilizada para el shRNA es complementaria sólo con el gen del EGFR de rata, para utilizar estas células hubo que expresar este último de manera exógena. El Dr. Jeffrey E. Segall generosamente nos cedió un plásmido que expresa el EGFR de rata acoplado a GFP (pEGFR-GFP), que usamos para transfectar células HEK 293T. La expresión del EGFR de rata de manera exógena a partir de un plásmido ofrece la ventaja de controlar las cantidades de proteína expresada, lo que nos da un control sobre el sistema que no es posible lograr con otras líneas. Por otro lado, el hecho de que la expresión del 
receptor esté acoplada a la expresión de una proteína fluorescente nos otorgó además la ventaja de seguir tanto la expresión como el posterior silenciamiento a través de la utilización de un microscopio de fluorescencia.

La Figura 19A muestra una fuerte expresión proteica del EGFR en el peso molecular esperado $(\sim 170 \mathrm{kDa})$. Por el contrario las células transfectadas con un vector vacío y $0 \mu \mathrm{g}$ de pEGFR-GFP dieron una señal mínima, correspondiente al EGFR de humano provisto por las células y detectado por el anticuerpo utilizado. En relación a esto último, la realización de esta curva de expresión nos sirvió también para evaluar la especificidad del anticuerpo, que como puede observarse en el Western blot representativo, reconoce al receptor tanto en el peso molecular adecuado como en las cantidades crecientes correspondientes a un aumento gradual en el vector de expresión. En cuanto a la fluorescencia, como puede observarse en la Figura 19B, la transfección con cantidades crecientes del plásmido produjo a su vez un incremento en la fluorescencia verde visualizada por epifluorescencia.

A
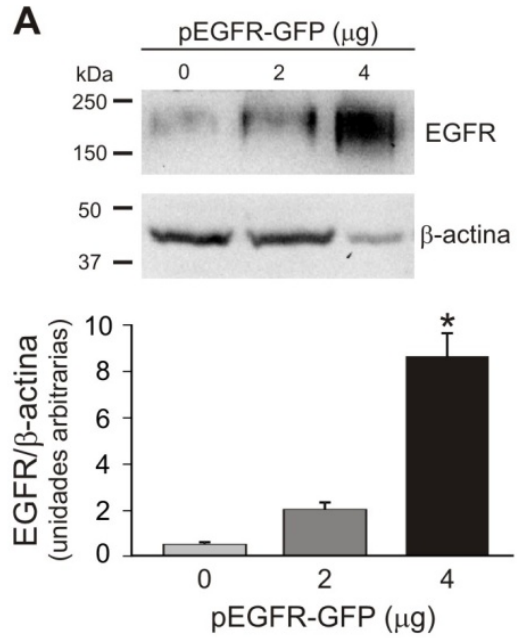

B
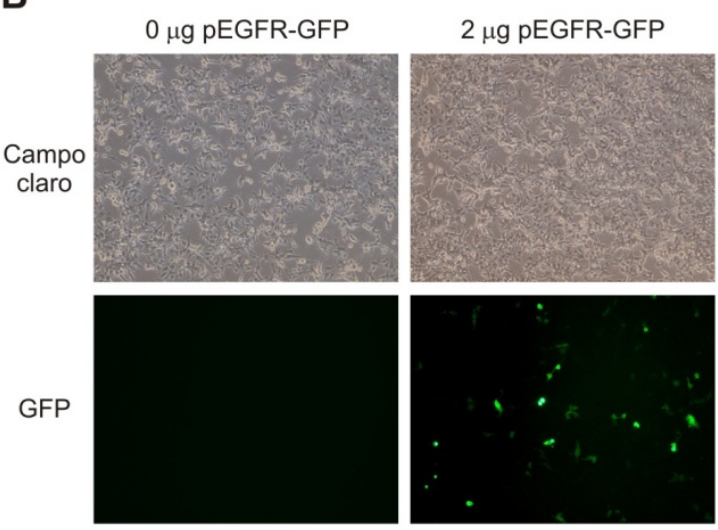

$4 \mu \mathrm{g}$ pEGFR-GFP
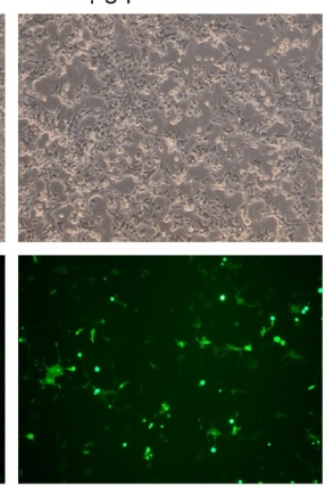

Figura 19. Expresión de EGFR en HEK 293T. A. Lisados de HEK 293T transfectadas con 0, 2, y $4 \mu \mathrm{g}$ de pEGFR-GFP, analizados por electroforesis. Western blot representativo y resultados promedio normalizados con $\beta$-actina (cada barra es $n=3$ ). B. Imágenes de campo claro y fluorescencia de cultivos transfectados con pEGFR-GFP (20X). ${ }^{*} \mathrm{p}<0,05$ vs 0 $\mu \mathrm{g}$ pEGFR-GFP.

\section{$\checkmark$ Curvas de silenciamiento.}

A fin de realizar una curva de silenciamiento para evaluar la funcionalidad del plásmido que codifica para el shRNA-EGFR (p-shEGFR), las células HEK 293T fueron co-transfectadas con una cantidad constante del plásmido de expresión pEGFR-GFP $(0,5 \mu \mathrm{g})$ y cantidades crecientes del plásmido silenciador p-shEGFR. Dado que la expresión del constructo EGFR-GFP es dirigida por el promotor fuerte de citomegalovirus (CMV) y llevada a cabo por la RNA polimerasa II, al igual que la de la proteína reportera DsRed contenida en el p-shEGFR, el aumento gradual en las 
cantidades de p-shEGFR implicaría mayor desvío de la RNA polimerasa II hacia el CMV del pshEGFR, y por lo tanto menor expresión del EGFR a partir del pEGFR-GFP. Para evitar estas diferencias producto de la disponibilidad de la polimerasa y no del silenciamiento en sí por el shRNA, las transfecciones desde $0 \mu \mathrm{g}$ a $2 \mu \mathrm{g}$ de p-shEGFR fueron compensadas con cantidades decrecientes (de $4 \mu \mathrm{g}$ a $2 \mu \mathrm{g}$ respectivamente) de p-shSCR, a fin de que en todos los puntos de la curva haya la misma cantidad relativa de RNA polimerasa sobre el pEGFR-GFP. Así, la expresión reducida del EGFR es sólo debido al silenciamiento del receptor por el shRNA.

La Figura 20A muestra una reducción notoria de la expresión del EGFR en células expresando el shRNA-EGFR. En concordancia, la disminución de la expresión de GFP se evidenció por la reducción en la fluorescencia verde de los cultivos co-transfectados, sin cambios evidentes en la fluorescencia roja, dado que el punto de $0 \mu \mathrm{g}$ de p-shEGFR tiene $4 \mu \mathrm{g}$ de p-shSCR para compensar como se explicó anteriormente (Figura 20B).

A
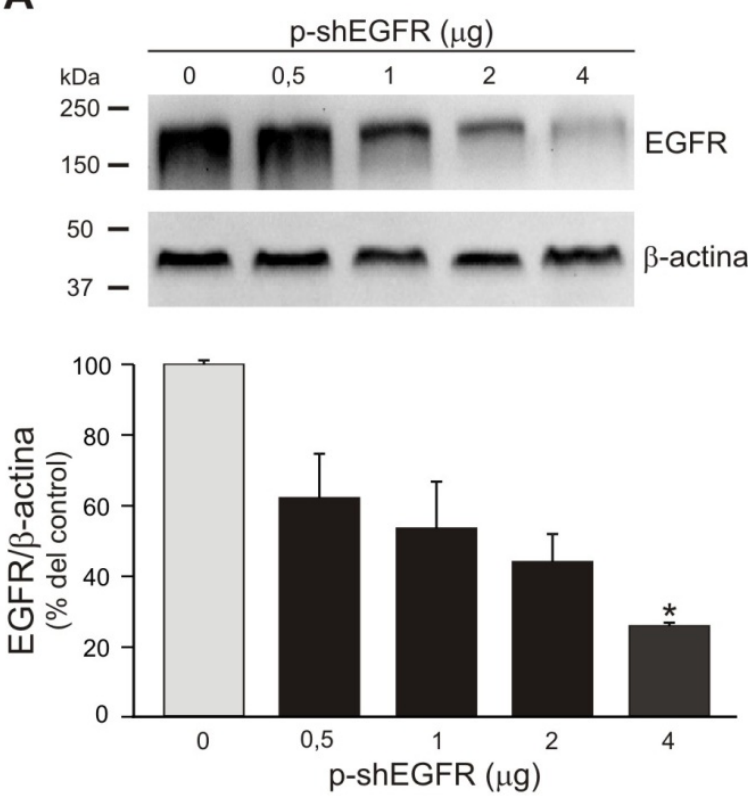

B
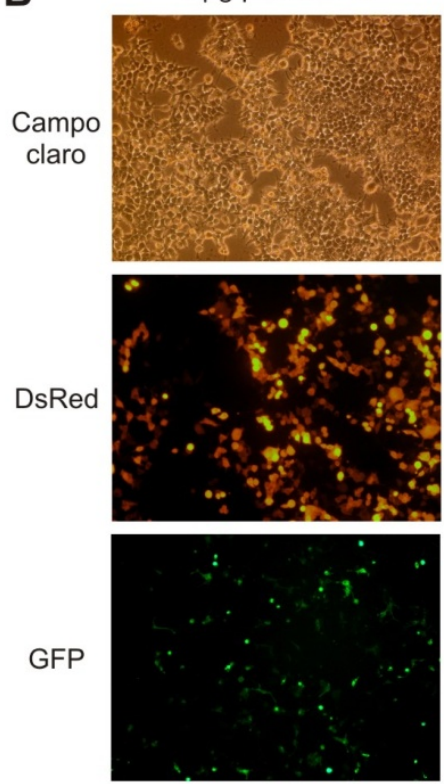

$4 \mu \mathrm{g}$ p-shEGFR
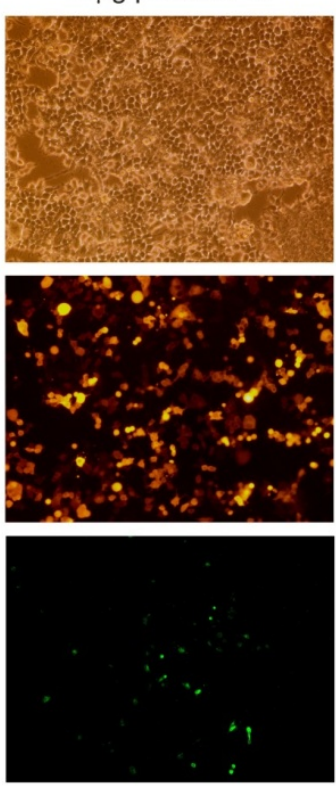

Figura 20. Silenciamiento de EGFR en HEK 293T. A. Lisados de HEK $293 \mathrm{~T}$ cotransfectadas con $0,5 \mu \mathrm{g}$ de pEGFR-GFP y cantidades crecientes de p-shEGFR $(0,0,5,1,2$ y $4 \mu \mathrm{g}$, cada barra corresponde a $\mathrm{n}=3$ ) B. Imágenes de microscopía de fluorescencia de cultivos transfectados con cantidades crecientes de p-shEGFR (20X). ${ }^{*} \mathrm{p}<0,05$ vs $0 \mu \mathrm{g}$ pshEGFR. 


\section{SECCIÓN II: ROL DEL EGFR EN LA SEGUNDA FASE DE FUERZA (SFF).}

\section{Silenciamiento específico del EGFR in vivo.}

A fin de estudiar in vivo el rol del EGFR en el desarrollo de SFF, tanto el lentivirus silenciador (l-shEGFR) como el control (l-shSCR) fueron inyectados en el miocardio de ratas Wistar, en dos sitios diferentes de la pared ventricular izquierda. Un mes después los animales fueron sacrificados y lo primero que se evaluó fue la distribución efectiva del lentivirus en el tejido cardíaco. Para tal fin, se determinó la fluorescencia roja provista por la proteína DsRed expresada a partir del virus en muestras provenientes del ventrículo izquierdo (VI) de los grupos l-shEGFR y lshSCR, así como también de animales Sham (inyectados con PBS). Una distribución irregular, en parches, fue observada en los dos grupos tratados con lentivirus, mientras que no se observó señal fluorescente en el grupo Sham (Figura 21).

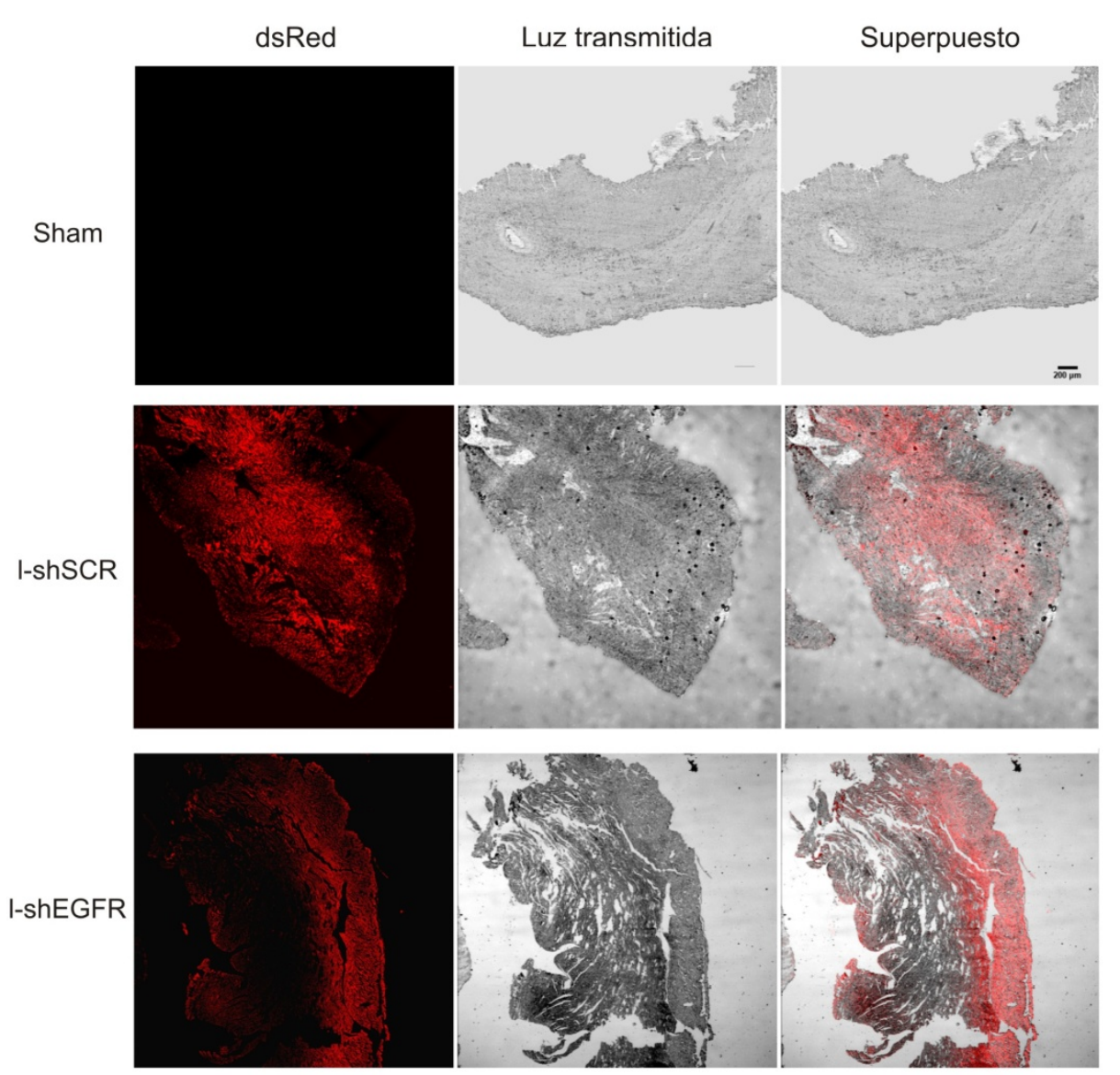

Figura 21. Distribución del virus. Imágenes representativas de microscopía confocal (4X) de muestras provenientes de corazones de los grupos l-shEGFR y l-shSCR, así como del grupo Sham. 
La expresión del EGFR medida por Western blot en homogenatos de VI mostró una reducción del 55\% en los corazones inyectados con 1-shEGFR comparados con los provenientes del grupo 1-shSCR (Figura 22).
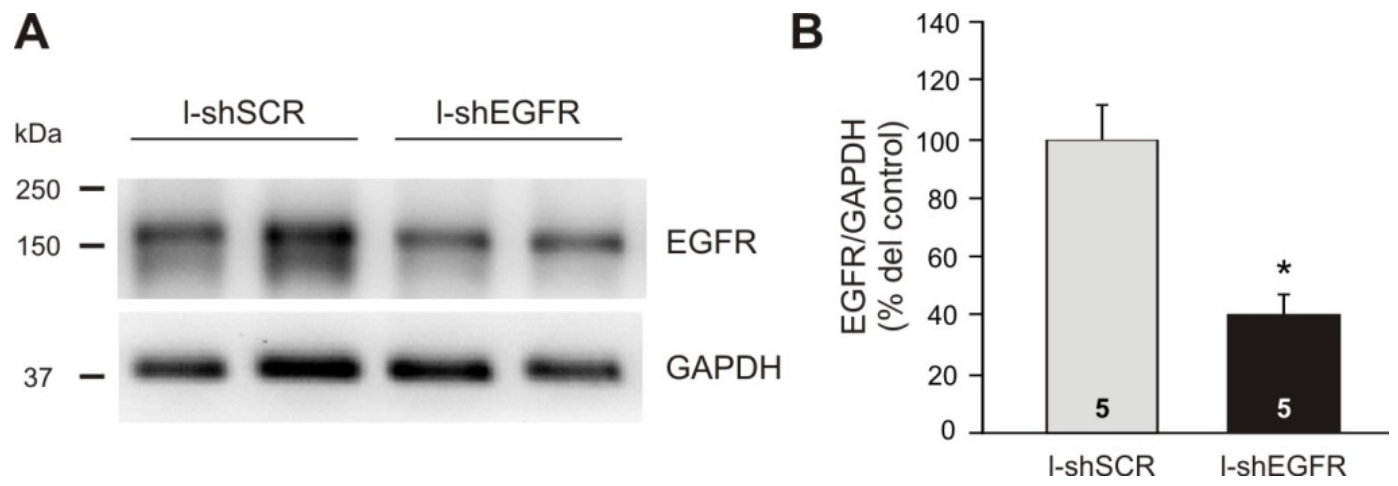

Figura 22. Silenciamiento de EGFR in vivo. Homogenato de VI de corazones de los grupos l-shEGFR y l-shSCR. A. Western blots representativos mostrando la expresión de EGFR en 2 muestras diferentes de cada grupo. B. Resultados promedios por grupo obtenidos a partir del análisis de densitometría de bandas. * $\mathrm{p}<0,05$ vs 1-shSCR.

La disminución en la expresión del EGFR no afectó la expresión de los otros miembros de la familia de receptores ErbB en corazón adulto, ErbB2 y ErbB4, mostrando que el lentivirus 1shEGFR es específico contra el EGFR (Figura 23). Esta especificidad del l-shEGFR se contrapone con la conocida inespecificidad del AG1478, uno de los inhibidores tirosina quinasa más utilizados para estudiar la función del EGFR, tal y como se discutirá en el apartado de Discusión.

A

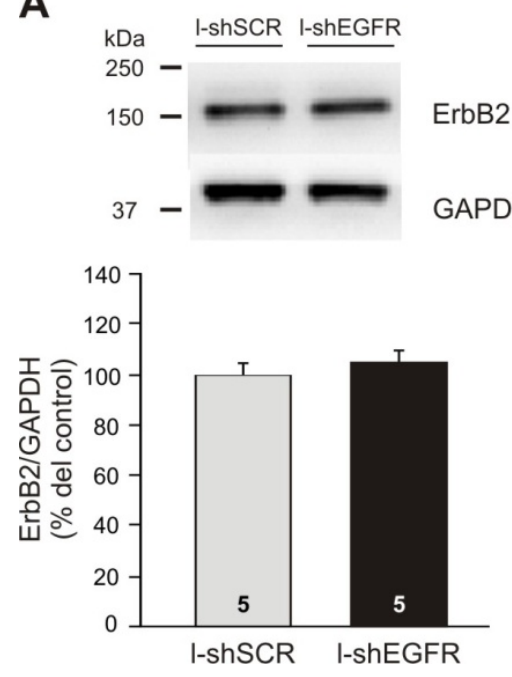

B
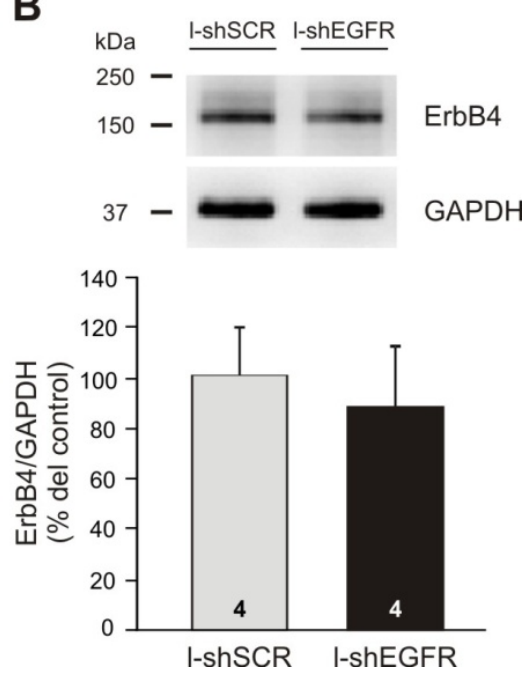

Figura 23. Expresión de ErbB2 y ErbB4. Expresión en VI del ErbB2 (A) y del ErbB4 (B), Western blot representativo en panel superior, $\mathrm{y}$ resultados promedio en panel inferior. 


\section{Parámetros morfométricos y ecocardiográficos.}

Una vez confirmado el silenciamiento del receptor, se estudiaron las consecuencias funcionales del tratamiento crónico con el virus en cuanto a morfometría y función del corazón. Los parámetros tanto ecocardiográficos como morfométricos fueron evaluados inmediatamente antes y después del sacrificio, y los resultados pueden observarse en la Tabla 1.

\begin{tabular}{|c|c|c|}
\hline & $\begin{array}{c}\text { l-shSCR } \\
(\mathrm{n}=8)\end{array}$ & $\begin{array}{c}\text { l-shEGFR } \\
(\mathrm{n}=11)\end{array}$ \\
\hline \multicolumn{3}{|l|}{ Parámetros morfométricos } \\
\hline PR $(\mathrm{gr})$ & $422,8 \pm 18,4$ & $381,6 \pm 18,1$ \\
\hline PC (gr) & $1,01 \pm 0,04$ & $0,90 \pm 0,04$ \\
\hline PVI (gr) & $0,80 \pm 0,04$ & $0,72 \pm 0,03$ \\
\hline LT (mm) & $42,26 \pm 0,44$ & $41,23 \pm 0,31$ \\
\hline $\mathrm{PC} / \mathrm{PR}\left(\mathrm{x} 10^{-3}\right)$ & $2,40 \pm 0,06$ & $2,36 \pm 0,04$ \\
\hline PVI/PR $\left(x 10^{-3}\right)$ & $1,89 \pm 0,07$ & $1,90 \pm 0,04$ \\
\hline $\mathrm{PC} / \mathrm{LT}\left(\times 10^{-3} \mathrm{gr} / \mathrm{mm}\right)$ & $23,91 \pm 0,87$ & $21,85 \pm 0,72$ \\
\hline PVI/LT $\left(\times 10^{-3} \mathrm{gr} / \mathrm{mm}\right)$ & $18,83 \pm 0,87$ & $17,58 \pm 0,61$ \\
\hline \multicolumn{3}{|c|}{ Parámetros ecocardiográficos } \\
\hline DDVI $(\mathrm{mm})$ & $6,32 \pm 0,15$ & $6,23 \pm 0,13$ \\
\hline $\operatorname{DSVI}(\mathrm{mm})$ & $2,46 \pm 0,08$ & $2,42 \pm 0,09$ \\
\hline FA $(\%)$ & $60,99 \pm 0,78$ & $61,26 \pm 0,72$ \\
\hline MVI (mg) & $706,4 \pm 30,6$ & $680,9 \pm 26,9$ \\
\hline MVI/PR (mg/gr) & $1,67 \pm 0,06$ & $1,80 \pm 0,04$ \\
\hline MVI/LT (mg/mm) & $16,69 \pm 0,62$ & $17,40 \pm 0,57$ \\
\hline $\mathrm{h} / \mathrm{r}$ & $0,55 \pm 0,01$ & $0,55 \pm 0,01$ \\
\hline
\end{tabular}

Tabla 1. Parámetros morfométricos y ecocardiográficos de l-shEGFR y l-shSCR. PR: peso de la rata; PC: peso del corazón; PVI: peso del ventrículo izquierdo; LT: longitud de la tibia; DDVI: diámetro diastólico del ventrículo izquierdo; DSVI: diámetro sistólico del ventrículo izquierdo; FA: fracción de acortamiento (expresado como acortamiento endocárdico (\%) en la Sección Materiales y Métodos); MVI: índice de masa ventricular, h/r: espesor parietal relativo.

No se encontraron diferencias significativas entre los grupos tratados con virus silenciador y control, indicando que ni la estructura ni la función cardíaca basal se ven afectadas por el silenciamiento cardíaco crónico del EGFR.

\section{Desarrollo de SFF en ratas con 1-shEGFR y l-shSCR.}

Ha sido demostrado que el bloqueo del EGFR por tratamiento con el inhibidor de tirosina quinasa AG1478 cancela la SFF junto con la activación de diversos factores propios de la ruta disparada por el estiramiento del corazón [91]. Sin embargo, como se mencionó previamente, este fármaco no es específico del receptor, pudiendo bloquear también la actividad del ErbB4.

En el presente trabajo se estudió el efecto funcional de silenciar al EGFR en el desarrollo de la SFF en respuesta al estiramiento agudo. El estiramiento de músculos papilares aislados 
provenientes del grupo inyectado con 1-shSCR generó la respuesta mecánica característica en dos fases sucesivas: un incremento inicial abrupto de la fuerza (producto del mecanismo de FrankStarling) seguido del incremento gradual conocido como SFF (Figura 24A, panel izquierdo). Sin embargo, cuando el mismo protocolo fue realizado en papilares del grupo inyectado con 1shEGFR, se observó la fase rápida inicial, pero la SFF fue completamente cancelada (Figura 24A, panel derecho). Los resultados promedio obtenidos para cada grupo experimental, que se pueden observar en la Figura 24B, demuestran claramente que el EGFR tiene un rol fundamental en la generación de la SFF al estiramiento, dado que la reducción de su expresión, aún sin ser completa, fue suficiente para cancelar por completo la respuesta contráctil secundaria.
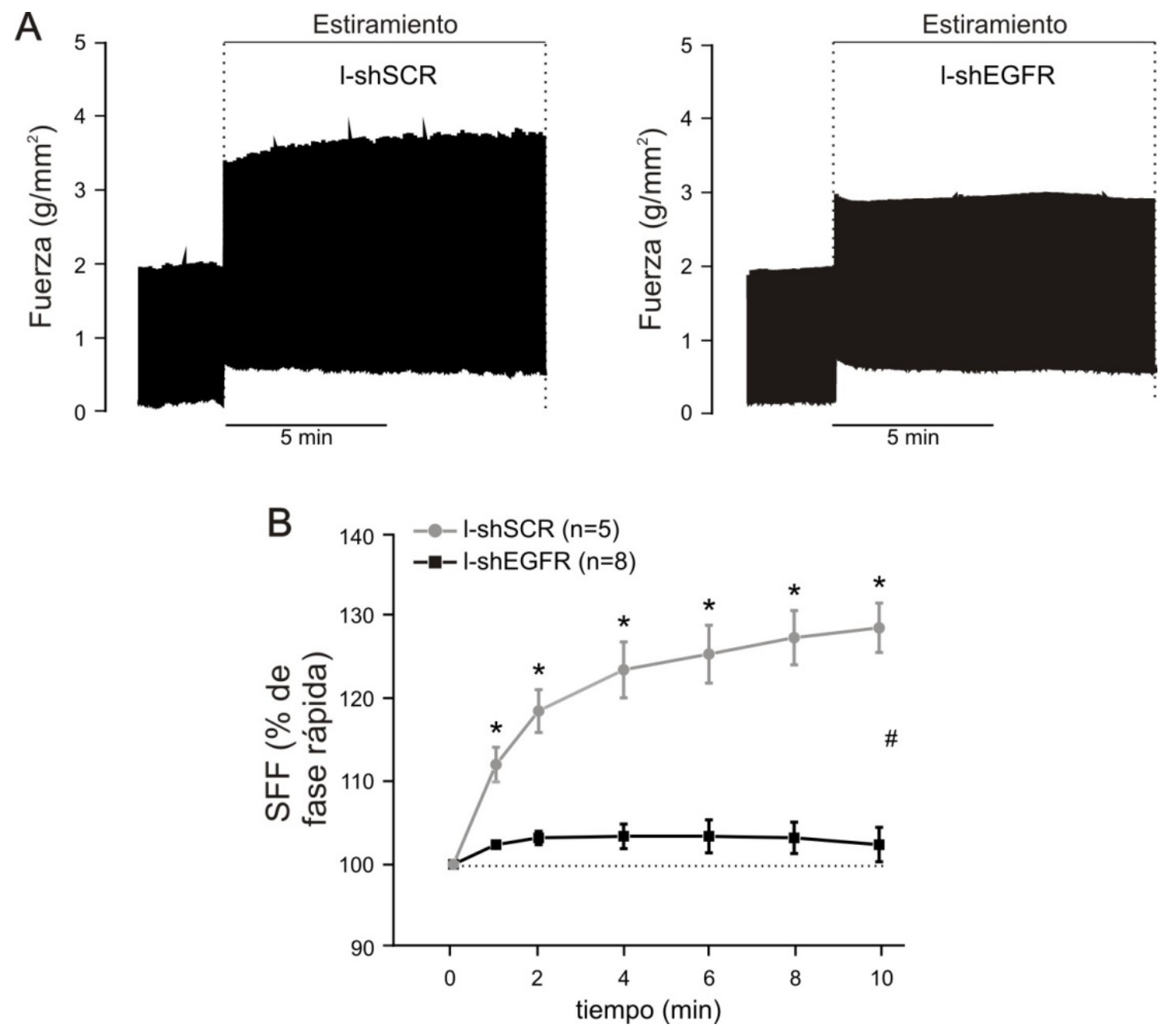

Figura 24. Activación del EGFR y SFF. A. Registros de fuerza representativos obtenidos en músculos papilares de los grupos 1-shSCR (izquierda) y l-shEGFR (derecha) sujetos a un incremento súbito de longitud desde el 92 al 98\% de la Lmax. B. Resultados de SFF promedio de los dos grupos experimentales expresados como porcentaje de la fase rápida inicial. * $\mathrm{p}<0,05$ vs tiempo cero de cada curva; \# $\mathrm{p}<0,05$ comparación de curva completa l-shSCR vs l-shEGFR 


\section{Activación del NHE1 por Ang II y silenciamiento del EGFR.}

La alcalinización del músculo cardíaco luego del estiramiento, en un medio libre de bicarbonato, es consecuencia de la activación del NHE1 mediada por el receptor AT1 [92]. Para seguir caracterizando los efectos funcionales del silenciamiento del EGFR en el miocardio, se evaluaron los cambios de $\mathrm{pHi}$ en respuesta a una dosis baja de Ang II ( $1 \mathrm{nmol} / \mathrm{L})$ en ambos grupos experimentales en ausencia nominal de bicarbonato. La dosis de Ang II utilizada surge de experimentos previos que mostraron que reproduce la vía de señalización disparada por el estiramiento, dando un incremento de fuerza similar al observado en la SFF [93]. Los resultados experimentales se observan en la Figura 25.
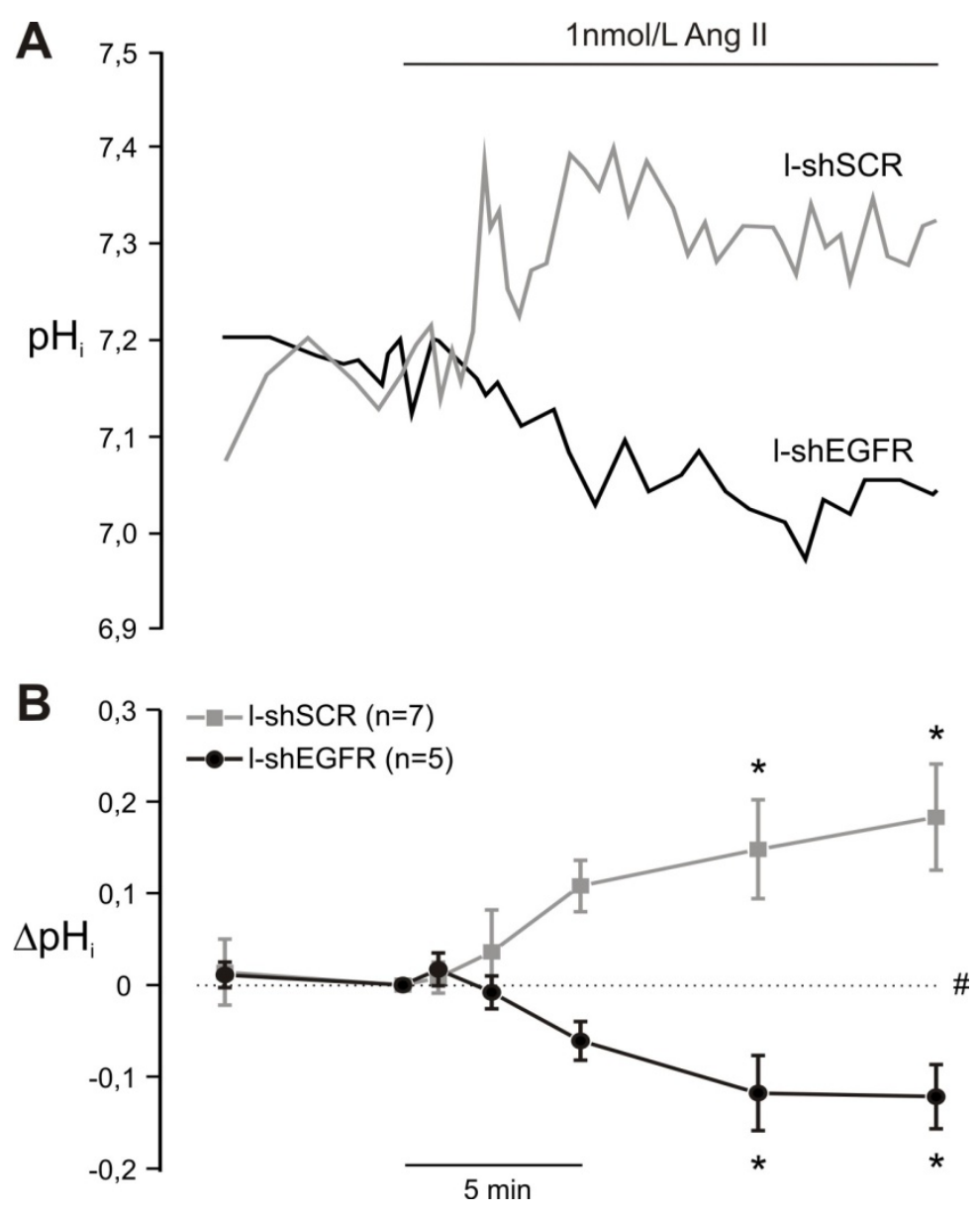

Figura 25. Activación del NHE1 por Ang II. Músculos papilares aislados de ambos grupos experimentales, cargados con BCECF y estimulados con $1 \mathrm{nmol} / \mathrm{L}$ de Ang II. A. Registro representativo de $\mathrm{pHi}$ para cada grupo experimental. B. Resultados promedio mostrados como $\Delta \mathrm{pHi}$ (diferencia de cada punto con respecto al $\mathrm{pHi}$ pre Ang II). * $\mathrm{p}<0,05$ para cada punto post Ang II vs tiempo cero (pre Ang) para cada curva; \# p <0,05 comparación entre curvas l-shSCR vs l-shEGFR.

$\mathrm{El} \mathrm{pH}_{\mathrm{i}}$ basal previo a la adición de Ang II fue similar en ambos grupos experimentales, como puede observarse en los registros típicos de Figura 25A, y en los valores promedio que se detallan a continuación: 7,17 $\pm 0,01$ para el grupo l-shSCR y 7,18 $\pm 0,01$ para el 1-shEGFR. Luego del estímulo con Ang se observó un incremento de $\mathrm{pHi}$ en el grupo l-shSCR, producto de la activación 
del NHE1 dado que en ausencia de bicarbonato es el único mecanismo alcalinizante operativo. Por el contrario, cuando se le agregó Ang II a los músculos papilares del grupo con 1-shEGFR, el pHi mostró una leve disminución en lugar de incrementar o mantener valores basales. Estos resultados, en conjunto con los mostrados en la Figura 24, sugieren que la activación del EGFR es crucial en la estimulación del NHE1 disparada por Ang II, y que por lo tanto juega un importante papel en el desarrollo de la SFF.

En la Figura 25B, correspondiente a los datos promedio de la diferencia de $\mathrm{pH}_{\mathrm{i}}$ para cada grupo, se observa una paulatina acidificación luego de la estimulación con Ang II en el grupo 1shEGFR. Pese a que en el presente trabajo no se han realizado experimentos adicionales para estudiar los motivos de este resultado inesperado, en la Sección de "Discusión" se desarrolla una posible explicación acerca de la posible causa de este hallazgo.

\section{Evaluación del estrés oxidativo en ausencia del EGFR.}

El incremento en la actividad del NHE1 durante el estiramiento del músculo cardíaco es dependiente de la formación de ROS [89]. En el presente trabajo, se utilizaron tiritas de VI para estudiar la producción de anión superóxido $\mathrm{O}_{2}{ }^{-}$en respuesta a la estimulación aguda con Ang II (1 $\mathrm{nmol} / \mathrm{L}$ ) o con EGF, que es un agonista específico del EGFR, en ambos grupos experimentales.
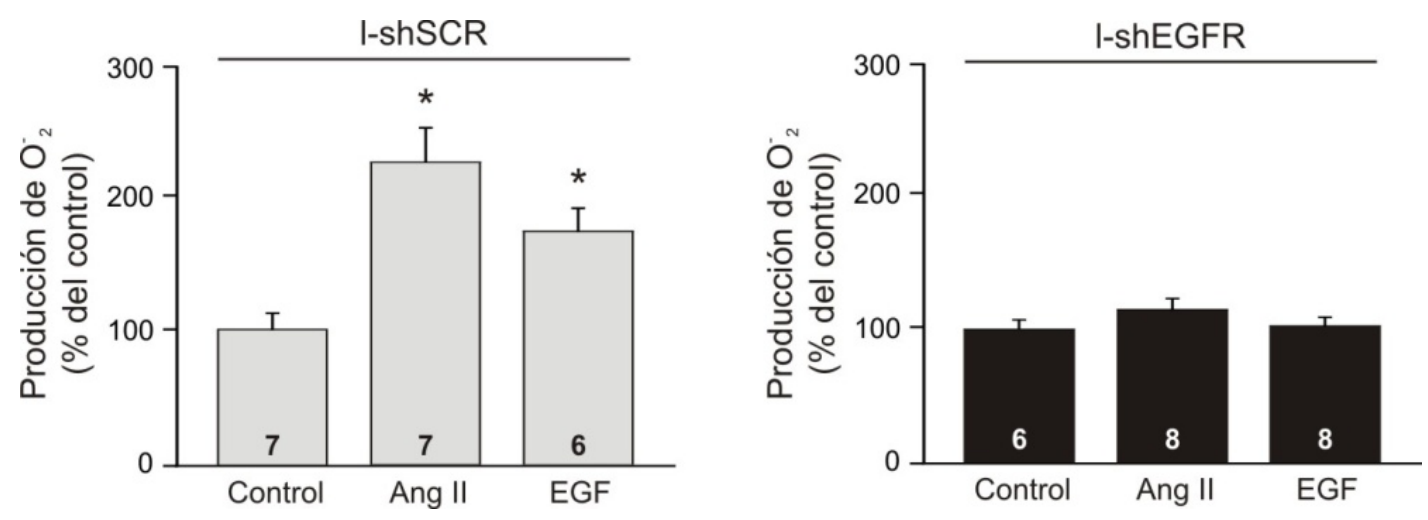

Figura 26. Producción de anión superóxido por Ang II y EGF. Tiritas de VI de ambos grupos estimuladas con Ang II (1 nmol/L) y con EGF $(0,1 \mu \mathrm{g} / \mathrm{mL})$. Resultados expresados como porcentaje del control no estimulado. ${ }^{*} \mathrm{p}<0,05$ vs control.

La Figura 26 muestra que la Ang II incrementa de manera significativa la producción de $\mathrm{O}_{2}$ en los corazones provenientes del grupo l-shSCR (panel de la izquierda), mientras que este efecto no se observa en los corazones provenientes del grupo con EGFR silenciado (panel de la derecha). Adicionalmente, cuando se utilizó EGF $(0,1 \mu \mathrm{g} / \mathrm{mL})$ para estimular directamente al receptor, se observó un aumento de la producción de $\mathrm{O}_{2}{ }^{-}$en el grupo l-shSCR que fue totalmente cancelado en el grupo l-shEGFR.

Dado que el tratamiento con el lentivirus es crónico, se evaluó el efecto del mismo sobre el 
estado redox basal del corazón, a fin de constatar que las diferencias encontradas en la estimulación en agudo (evidenciadas en la Figura 26) eran propias de la activación de la ruta propuesta, y no debidas a cambios en la maquinaria de generación de especies reactivas del oxígeno. La peroxidación lipídica, estimada por cuantificación de T-BARS en ambos grupos experimentales, no mostró diferencias significativas entre ellos (Figura 27A), indicando que el estrés oxidativo basal fue similar pese a que el grupo l-shEGFR tiene la expresión del receptor reducida.

A

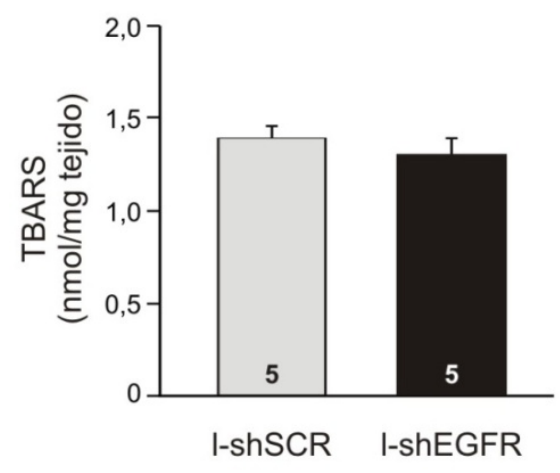

C

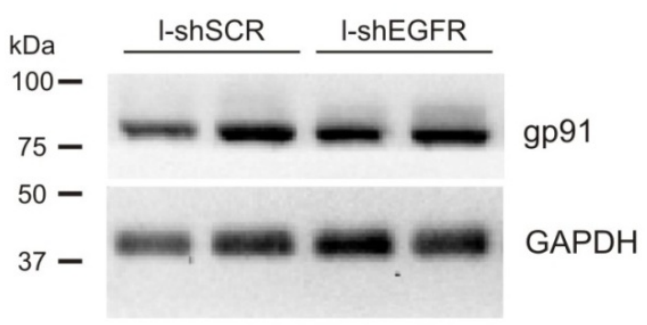

B
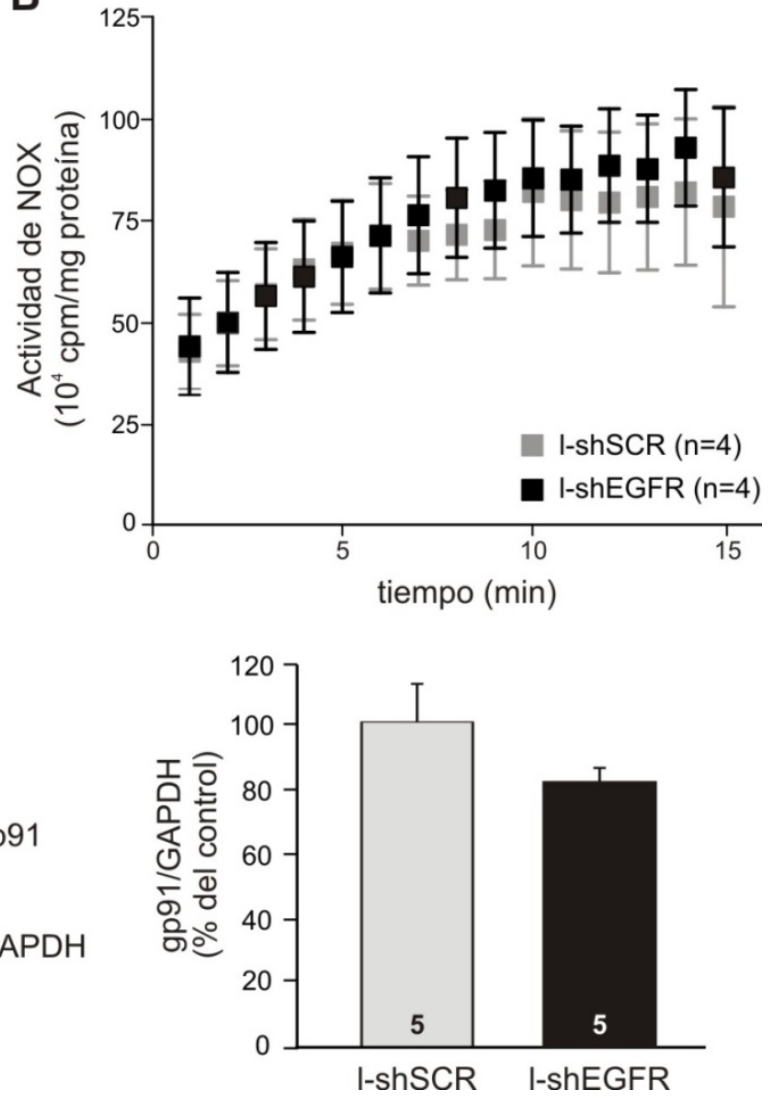

Figura 27. Estado redox basal en los grupos tratados. A. Medición de la peroxidación lipídica en homogenato de VI mediante la técnica de T-BARS. B. Actividad basal de NOX medida en un luminómetro a partir de la producción se superóxido con el sustrato NAD. C. Expresión proteica de gp91 en homogenato de VI, Western blot representativo en el panel izquierdo y resultados promedio por grupo en el derecho.

Por otro lado, la NADPH oxidasa 2 (NOX2), una de las fuentes de producción de $\mathrm{O}_{2}^{-}$más importantes del corazón, puede activarse por estimulación con Ang II [94] y a su vez puede modificar su expresión en respuesta a diferentes estímulos [62]. En el presente trabajo, ni la actividad de la NOX total (Figura 27B), ni la expresión proteica de la subunidad de membrana gp91 correspondiente a la NOX2 (Figura 27C), mostraron diferencias basales entre los grupos experimentales, indicando que la reducción crónica de la expresión del EGFR no modifica ni la expresión ni la actividad basal de la NOX2. 


\section{Activación de quinasas redox-sensibles: ERK1/2 y p90RSK.}

Previamente se ha demostrado que las quinasas redox-sensibles ERK1/2 y p90RSK son responsables de la activación del NHE1 durante el estiramiento miocárdico [89]. También se probó que el tratamiento con AG1478 previene la fosforilación de ERK1/2 provocada por el estiramiento [91]. Dado que el lentivirus silenciador del EGFR permite bloquear de manera específica al receptor, se estudió la activación de estas quinasas frente a diversos estímulos en nuestro modelo.

Nuevamente debido a la cronicidad del tratamiento con lentivirus, lo primero que se hizo fue medir la expresión total de ambas quinasas en homogenato de VI, para corroborar que no se hubieran generado modificaciones por el tratamiento. Como se observa en la Figura 28, ni ERK1/2 ni p90RSK cambiaron su expresión en el grupo l-shEGFR con respecto al l-shSCR.
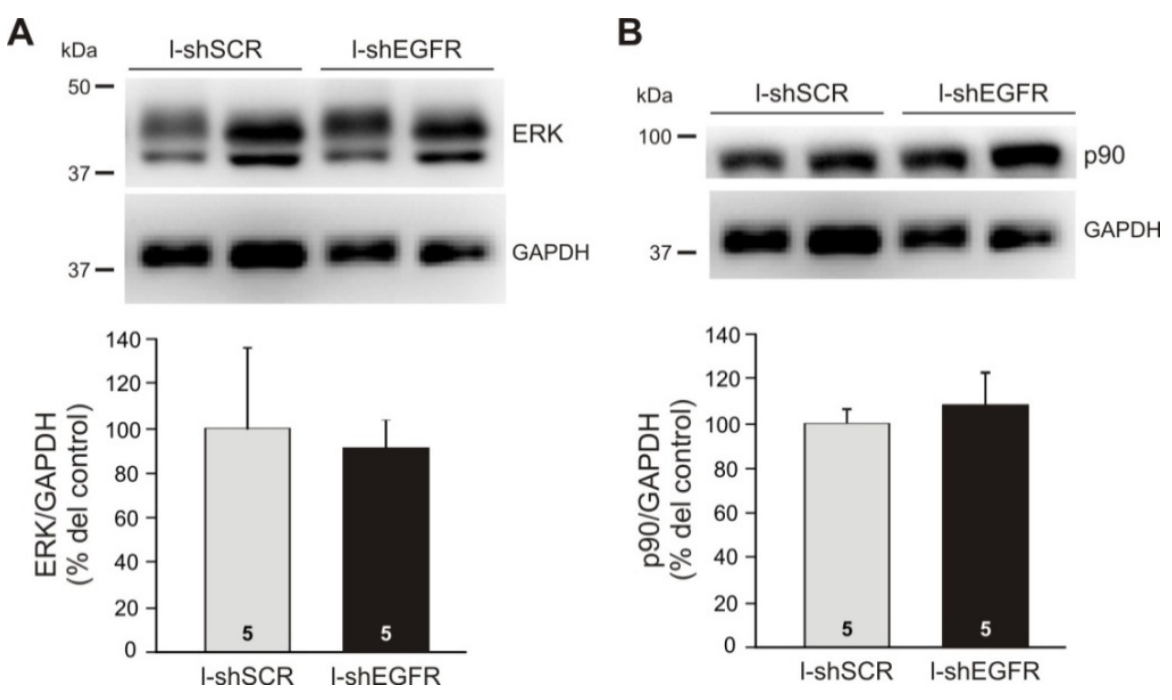

Figura 28. Expresión de ERK1/2 y p90RSK. Western blots de homogenatos de VI. Paneles superiores: Western blots representativos para cada quinasa; paneles inferiores: resultados promedio por grupos. A. Expresión de ERK1/2. B. Expresión de p90RSK.

Para evaluar la activación de las quinasas, trocitos de VI de corazones de ambos grupos fueron estimulados con Ang II ( $1 \mathrm{nmol} / \mathrm{L})$ o EGF $(0,1 \mu \mathrm{g} / \mathrm{mL})$ por 15 minutos, y congelados inmediatamente después. Los homogenatos generados a partir de esas muestras se corrieron en un Western blot, y los resultados del análisis muestran un incremento en la fosforilación de ERK1/2 en el grupo 1-shSCR, que no se observa en el grupo 1-shEGFR (Figura 29). En las ratas tratadas con 1shSCR, el aumento de la fosforilación de ERK1/2 luego de la estimulación con EGF es significativo, mientras que la estimulación con Ang II dio una marcada tendencia al aumento que no alcanzó niveles de significación estadística $(\mathrm{p}=0,054)$.

En el grupo inyectado con 1-shEGFR, los pedacitos tratados con Ang II mostraron una fosforilación de ERK1/2 similar a la de las muestras no estimuladas (Figura 29B). Los resultados de las muestras tratadas con EGF mostraron sin embargo una media más alta, y un error grande, lo cual puede explicarse por el hecho de que una de las cuatro muestras analizadas presentaba un 
exceso de fosforilación comparada con el resto de las muestras del miso grupo. El análisis del duplicado de esta muestra generó el mismo resultado. De todos modos el resultado de la estimulación con EGF en este grupo sigue siendo igual al control sin estimular (según el análisis estadístico), indicando que el silenciamiento del EGFR impide la activación de ERK1/2 tanto por Ang II como por EGF.

A
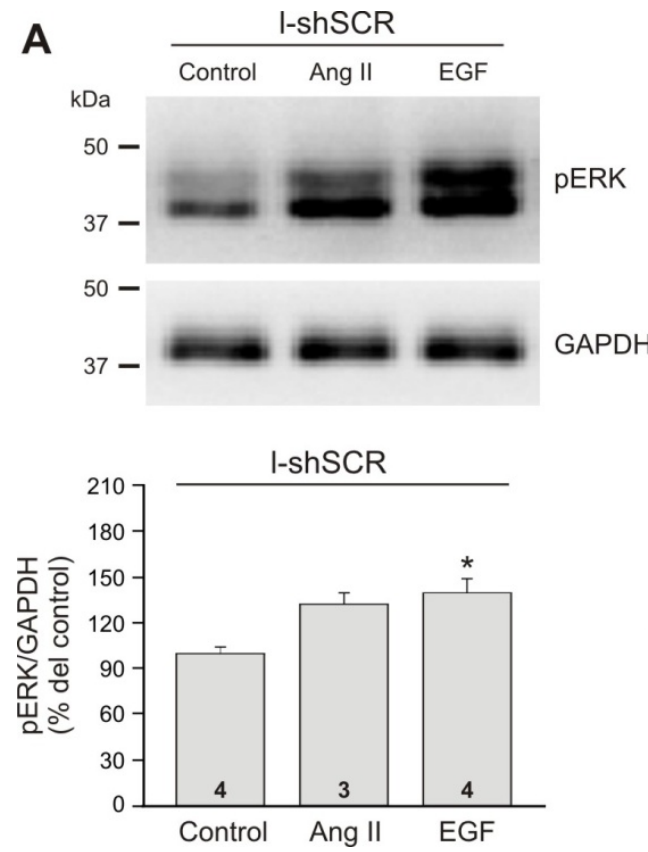

B
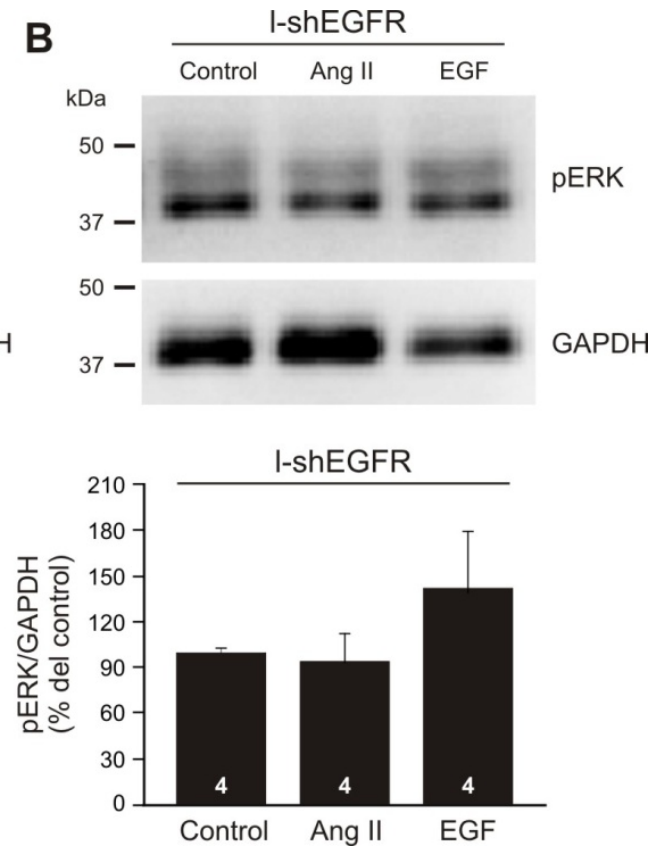

Figura 29. Activación de ERK1/2. Trocitos de VI estimulados con Ang II (1 nmol/L) y con EGF $(0,1 \mu \mathrm{g} / \mathrm{mL})$. Paneles superiores: Western blots representativos para cada grupo; paneles inferiores: resultados promedio. A. Fosforilación de ERK1/2 en el grupo 1-shSCR. B. Fosforilación de ERK1/2 en el grupo l-shEGFR. * $\mathrm{p}<0,05$ vs control.

En cuanto a la fosforilación de p90RSK se obtuvieron resultados similares (Figura 30). En el grupo 1-shSCR, tanto la estimulación con Ang II como con EGF activaron la quinasa aumentando su fosforilación, mientras que en el grupo con el EGFR silenciado, ninguno de los dos estímulos lograron una diferencia de fosforilación significativa con respecto al control sin estimular. Estos resultados indican que el EGFR es necesario para la activación de p90RSK por Ang II y por EGF. 
A
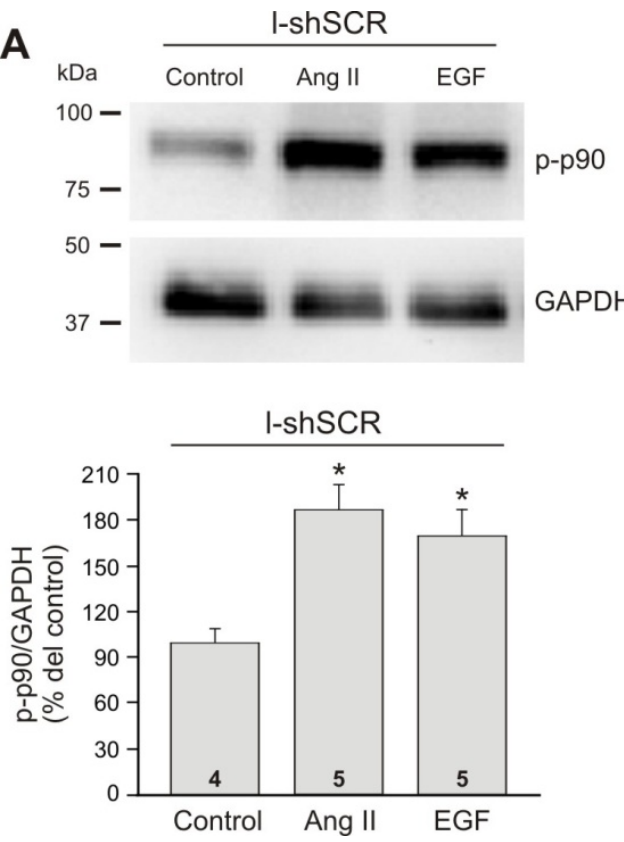

B
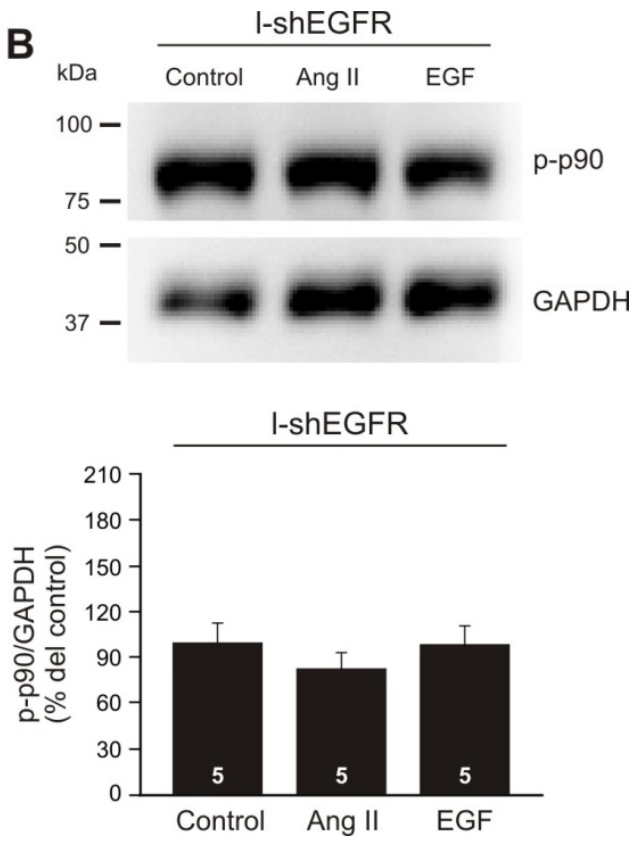

Figura 30. Activación de p90RSK. Trocitos de VI estimulados con Ang II (1 nmol/L) y con EGF $(0,1 \mu \mathrm{g} / \mathrm{mL})$. Paneles superiores: Western blots representativos para cada grupo; paneles inferiores: resultados promedio. A. Fosforilación de p90 en el grupo l-shSCR. B. Fosforilación de p90 en el grupo l-shEGFR. * p $<0,05$ vs control. 


\section{SECCIÓN III: PARTICIPACIÓN DEL EGFR EN LA HIPERTROFIA CARDÍACA.}

Una vez demostrada la funcionalidad in vivo del lentivirus contra el EGFR, y habiendo utilizado esta herramienta para demostrar su participación en la SFF, se lo utilizó para evaluar el rol del receptor en la HCP.

El primer modelo de HCP utilizado fue el generado mediante la administración continua de Ang II a ratas Wistar, por medio de bombas osmóticas. La dosis administrada fue subpresora, a fin de que la hipertrofia generada no sea por el aumento de presión, sino por la característica pro hipertrófica de la Ang II en sí misma. Sin embargo, al iniciarse los trabajos con este modelo se encontraron inconvenientes que nos llevaron a reemplazarlo por otro. El principal problema fue que el estímulo con Ang II aumentó la expresión del EGFR de manera significativa en el grupo con 1-shSCR respecto del grupo control sin bomba (Figura 31). La inyección con 1-shEGFR permitió reducir la expresión del receptor con respecto al grupo con l-shSCR, pero apenas al nivel del grupo control, lejos de poder disminuirla por debajo del mismo.

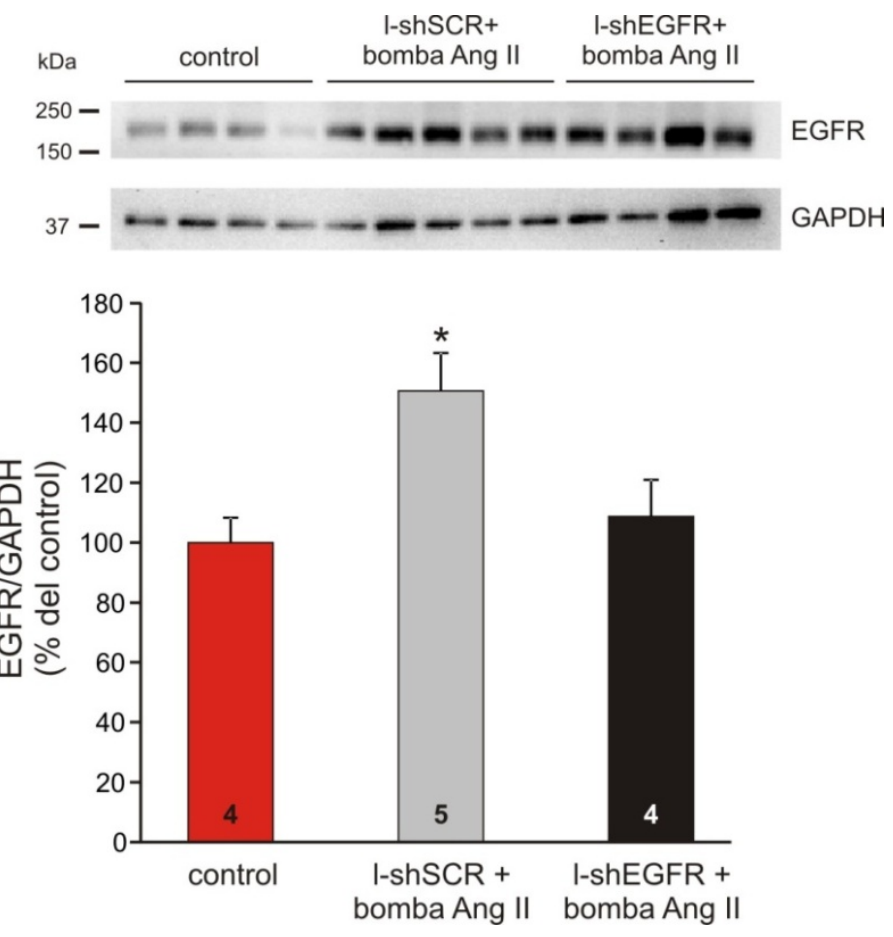

Figura 31. Expresión del EGFR en modelo de HCP con bomba de Ang II. Homogenato de VI de corazones de los grupos 1-shEGFR y 1-shSCR con bombas de Ang II. Panel superior: Western blot de todas las muestras; panel inferior: resultados promedios por grupo. ${ }^{*} \mathrm{p}<0,05$ vs control.

Como ya se mencionó en la introducción existen trabajos que demuestran la participación del EGFR en el proceso de trans-activación. El objetivo perseguido en esta Sección fue caracterizar esta participación de una manera más específica y localizada en el tejido cardíaco, dada la amplia 
expresión del receptor en distintos tejidos, así como sus numerosas posibilidades de activación. Esto último puede producirse por heterodimerización con otros miembros tales como ErbB2 y ErbB4, lo cual demandaría la mitad de moléculas de EGFR activas por HB-EGF, el ligando involucrado en el proceso. En este sentido, la caracterización del EGFR en esta vía implica poder reducir su expresión lo máximo posible, tratando simultáneamente de reducir posibles modificaciones involuntarias del contexto celular. Se sabe que la integración del DNA viral en el genoma del huésped ya es una gran alteración. Por otro lado, la inyección del virus implica cierto daño tisular y desencadena un proceso inflamatorio, que cuanto más minimizado sea, menor será el número de variables introducidas en el fenómeno a estudiar. Por estas razones es deseable poder lograr el mayor silenciamiento con el menor volumen de virus posible a inyectar. El objetivo buscado con el modelo de hipertrofia inducida con infusión de Ang II fue activar la ruta de transactivación del EGFR desde el receptor AT1. El aumento de la expresión del componente que específicamente se quería caracterizar, el cual obviamente se pretendía que permaneciera inalterado luego de la intervención, fue un hallazgo inesperado. En este marco, se posible especular que si la administración exógena de Ang II induce la sobreexpresión del EGFR en esta ruta, es probable que se produzca una exacerbación de la misma y activación de rutas alternativas por heterodimerización, cambiando plenamente el escenario originalmente planteado en la hipótesis de trabajo al respecto. Conocer la causa y las consecuencias de esta alteración sería sumamente interesante pero excede los objetivos inicialmente planteados para el desarrollo de esta Tesis Doctoral. Sumado a esta dificultad, el título de virus usado para silenciar la expresión en las ratas Wistar no fue suficiente para reducir la expresión del EGFR por debajo de su nivel basal en este modelo, lo que podría indicar que a pesar de la reducción del nivel de EGFR, existe suficiente cantidad de receptor como para permitir un normal procesamiento de la señal de trans-activación inducida por Ang II. Lamentablemente, no pudimos realizar un dosaje de Ang II que permita descartar posibles anomalías en el funcionamiento de las bombas, dado que en caso de que la liberación del péptido fuera excesiva podría estar activando otra ruta alternativa a la de la transactivación del EGFR. En resumen, el modelo se vio ampliamente distorsionado respecto a lo pensado previamente, independientemente si el EGFR estaba o no silenciado.

Una aparente solución a este problema podría haber sido intentar aumentar el silenciamiento del EGFR a través del incremento de la dosis de lentivirus inyectado. Sin embargo, el aumento de las partículas virales inyectadas no es garantía de éxito. Sumado a los problemas mencionados anteriormente (inserción en el genoma, proceso inflamatorio), una mayor dosis de lentivirus no necesariamente lleva a un mayor silenciamiento dado que se produce una saturación del sistema exportador nuclear [95]. De hecho, la misma bibliografía muestra que la competencia del shRNA con los miRNAs endogénos por los sistemas de transporte del núcleo al citosol puede causar daños severos en el organismo [96]. Otra alternativa podría haber sido aumentar la duración del tratamiento con lentivirus. Sin embargo, numerosos trabajos han mostrado que a partir del tercer día el efecto deseado (sea silenciar o sobre-expresar) ya se consigue. Más aún, el mismo efecto se mantiene en igual magnitud hasta los 3 meses de tratamiento, permitiendo suponer que no lograríamos mejores resultados extendiendo el tiempo de tratamiento con lentivirus $[97,98]$. 
Ante este escenario, se decidió probar la hipótesis en ratas espontáneamente hipertensas (SHR), disponibles en el bioterio del CIC y que representan un modelo de hipertrofia que también involucra a la Ang II. Las ratas SHR fueron desarrolladas en 1963 [99], como un modelo de hipertensión genética similar en algunos aspectos a la hipertensión esencial humana [100]. Es un modelo complejo pero ampliamente caracterizado y utilizado. En tal sentido, Dang y col. [101] reportaron un elevado tono simpático en una fase inicial del desarrollo, que se normaliza al cabo de 5 semanas de vida, así como elevados niveles de Ang II en ventrículo izquierdo entre las 13 y 28 semanas de desarrollo sin cambios en los niveles plasmáticos del péptido [101]. Estos resultados concuerdan con lo descripto antes por Dell'Italia y col. en perros a los que se les había infundido Ang I [102] y en el reciente análisis temporal en animales SHR por Silva y colaboradores [103]. Por otro lado, demostrando el rol clave que la Ang II tiene en el desarrollo de HC en SHR, numerosos trabajos muestran la reversión de la patología mediante la administración de bloqueantes del receptor AT1 [104-106] o inhibidores de la enzima convertidora de Ang II [104, 107, 108].

\section{Distribución del virus y silenciamiento del EGFR en ratas SHR.}

Se trabajó con ratas SHR macho de 3 meses al inicio del tratamiento, y se las dividió en dos grupos, uno inyectado con 1-shSCR y otro con 1-shEGFR. La inyección se realizó en dos sitios de la pared anterolateral del VI, y los animales fueron sacrificados un mes después. Lo primero que se evaluó fue la distribución efectiva del virus por microscopía confocal y se observó, al igual que en los animales de la Sección II, una distribución irregular en los dos grupos tratados con lentivirus, mientras que no se observó señal fluorescente en el grupo inyectado con buffer PBS (Figura 32).

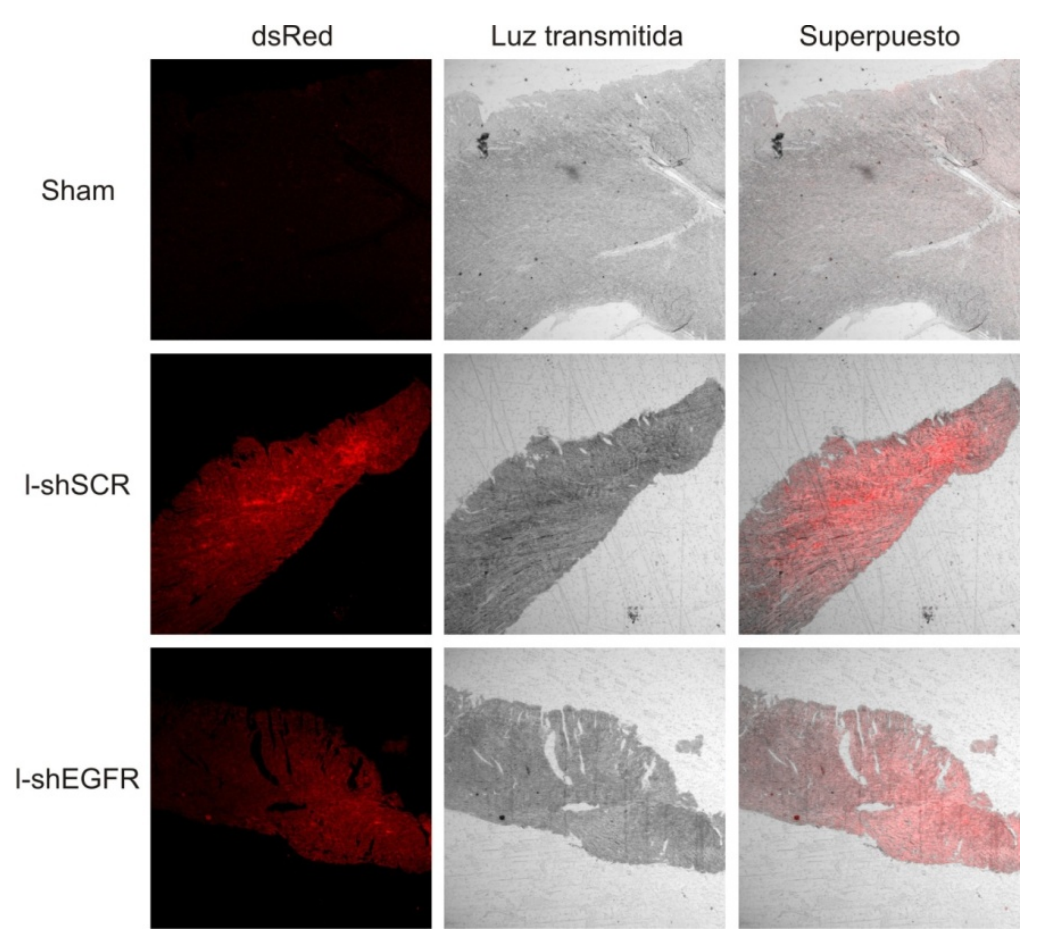

Figura 32. Distribución del virus. Imágenes representativas de microscopía confocal (4X) de muestras provenientes de VI de corazones de los grupos l-shEGFR y l-shSCR, así como del grupo Sham. 
La expresión del EGFR medida en homogenatos de VI de ratas SHR después de 30 días de tratamiento, mostró una reducción de $\sim 40 \%$ en los corazones inyectados con 1-shEGFR comparados con los provenientes del grupo l-shSCR, como puede observarse en la Figura 33, tanto en los Western blots representativos (panel A) como en los resultados promedios por grupo (panel B). Esta reducción no afectó la expresión del ErbB2 ni del ErbB4 (Figura 34A y B respectivamente). Esta especificidad en el bloqueo del receptor implica una diferencia con el bloqueo por inhibidores farmacológicos (tales como el AG1478) o por inhibidores como la silibinina (que no tiene una especificidad probada por el EGFR sino que podría tener otros blancos moleculares). De este modo, los efectos observados en este trabajo sobre los distintos parámetros medidos son producto del bloqueo específico y localizado del EGFR, sin implicar a los otros miembros de la familia ErbB, o a otros órganos y a los vasos sanguíneos.

A

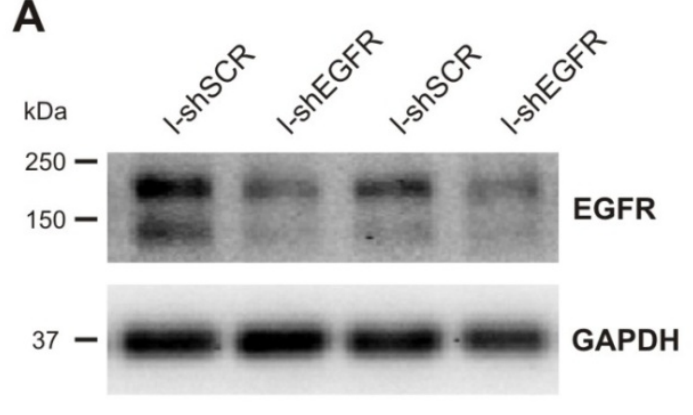

B

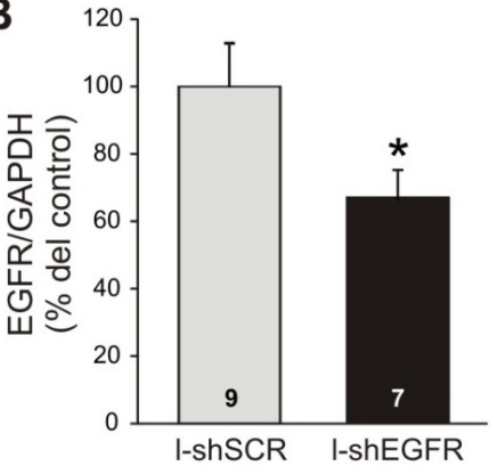

Figura 33. Silenciamiento de EGFR en SHR. Homogenato de VI de los grupos 1-shSCR y 1-shEGFR. A. Western blots representativos mostrando la expresión de EGFR referida a la de GAPDH. B. Resultados promedios por grupo. *p<0,05 vs l-shSCR.

A
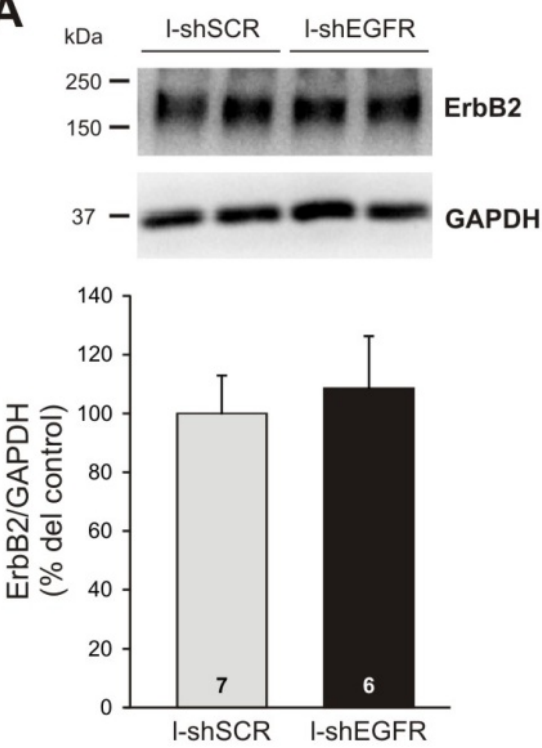

B
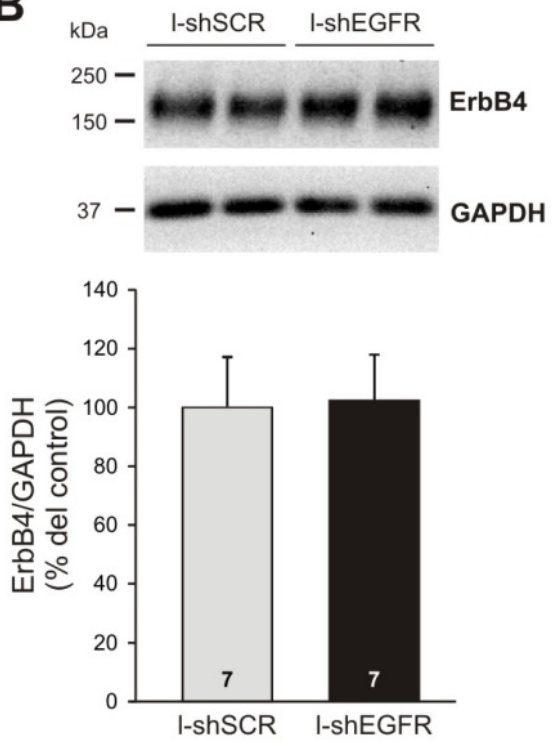

Figura 34. Expresión de ErbB2 y ErbB4 en SHR tratadas. Expresión cardíaca del ErbB2 (A) y ErbB4 (B), Western blot representativo en el panel superior, y resultados promedio en el panel inferior, respectivamente. 


\section{Evaluación de la hipertrofia cardíaca.}

El desarrollo de $\mathrm{HCP}$ en los grupos tratados se evaluó mediante diversos parámetros. Como se observa en el panel A de la Figura 35, el silenciamiento cardíaco del EGFR provocó una disminución significativa de la HC medida a través de los cocientes PVI/PR y PVI/LT. En concordancia, el análisis del área de sección transversal de los cardiomiocitos mediante cortes histológicos demostró una disminución significativa de $24 \%$ en el grupo tratado con 1-shEGFR en comparación con el de 1-shSCR (Figura 35B).
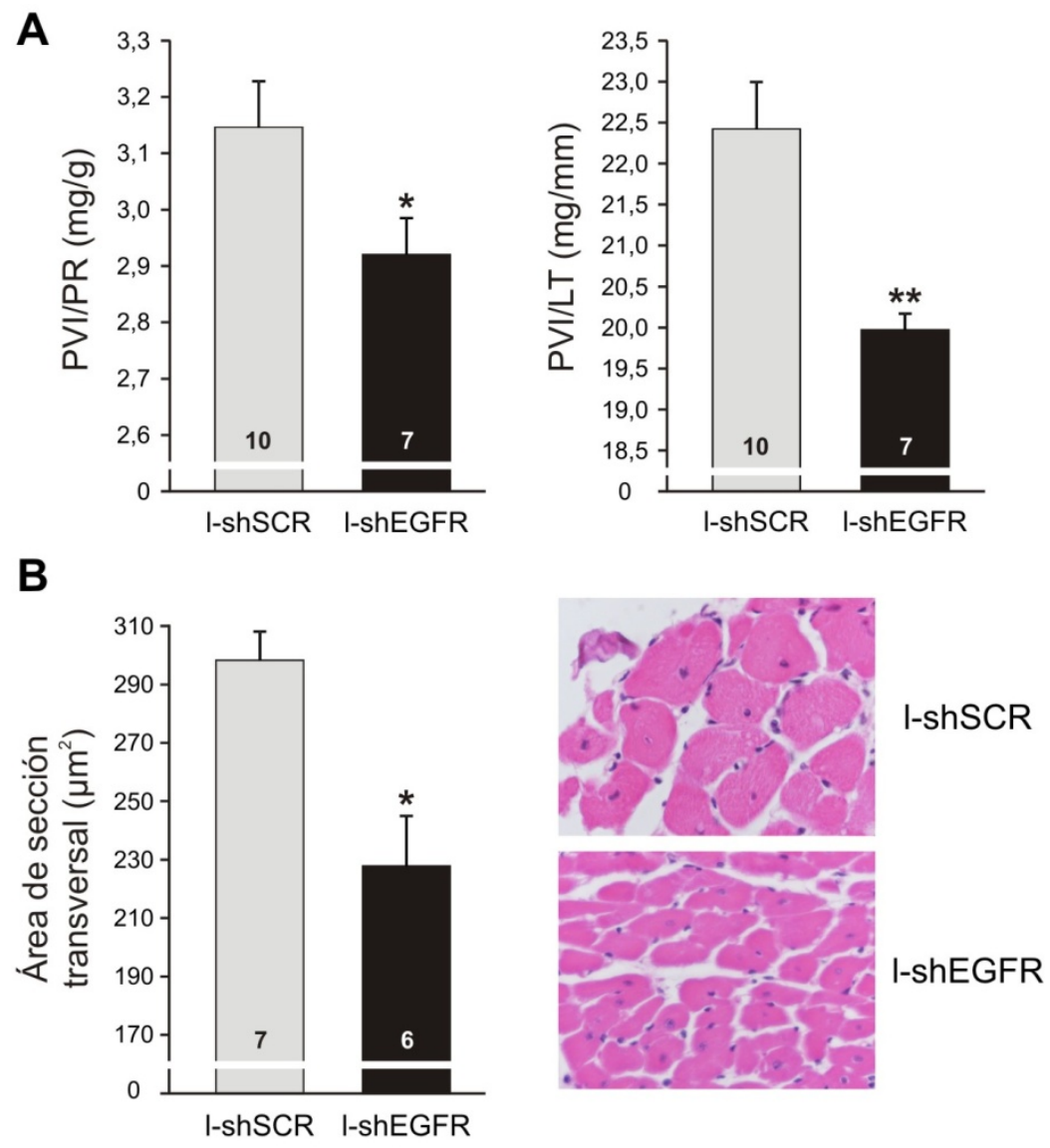

Figura 35. HCP por parámetros morfométricos y área de miocitos. A. PR: peso de la rata; PC: peso del corazón; PVI: peso del ventrículo izquierdo; LT: longitud de la tibia. Resultados promedio para los grupos con 1-shSCR y l-shEGFR. B. Valores promedio por grupo del área de sección transversal de los miocitos, y fotos de microscopía representativas (40X). ${ }^{*} \mathrm{p}<0,05$ vs $1-\mathrm{shSCR} ;{ }^{* *} \mathrm{p}<0,01$ vs 1 -shSCR.

\section{Estudio de la presión arterial y evaluación de la función cardíaca por ecocardiografía.}

La presión arterial fue medida de forma semanal, y como puede observarse en la Figura 36, no se modificó por el silenciamiento cardíaco del EGFR. Si bien se ha reportado disminución de la 
presión arterial en SHR por inhibición del EGFR [45], esta inhibición fue realizada con una secuencia anti sentido administrada de forma sistémica, afectando posiblemente la expresión del EGFR en los vasos sanguíneos, donde el receptor favorece la vasoconstricción [109]. En el modelo utilizado en el presente trabajo, la inhibición del EGFR con el lentivirus es acotada al corazón, sin implicar a los vasos, con lo que no esperábamos una disminución de la presión arterial. Resultados similares se obtuvieron inhibiendo con la misma técnica y en el mismo modelo al NHE1, efector corriente abajo de la activación del EGFR [83].

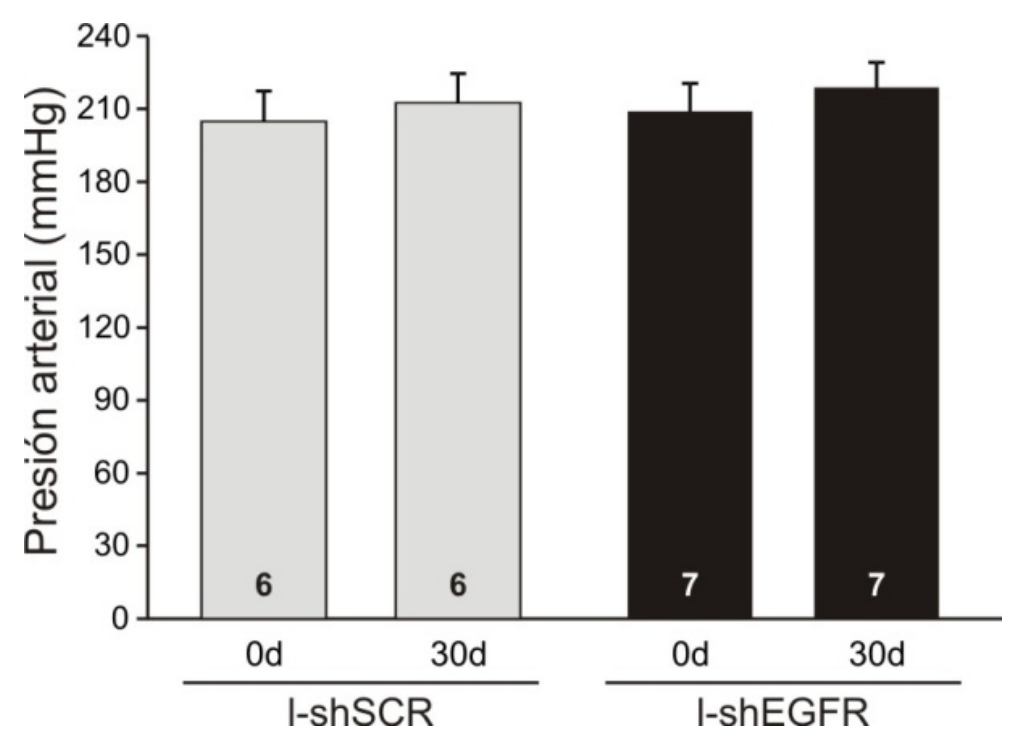

Figura 36. Presión arterial. Presión arterial promedio para cada grupo medida al inicio del tratamiento (0 días, $0 \mathrm{~d})$ y al final (30 días, 30d).

La función cardíaca se analizó por ecocardiografía, comparándola al inicio y al final del tratamiento en cada grupo experimental. Los animales inyectados con 1-shSCR mostraron al final del tratamiento una disminución significativa de la fracción de acortamiento endocárdico (Figura 37A), y una disminución que no llega a ser significativa $(p=0,060)$ pero muestra una marcada tendencia, en el acortamiento medio ventricular (Figura 37B). Este resultado sugiere que la progresión de la HC en estos animales se acompaña de un deterioro de la función cardíaca. Por el contrario, el grupo inyectado con l-shEGFR no mostró diferencias significativas al inicio y al final del tratamiento para ninguno de los parámetros (Figura 37). Considerando que ambos grupos tuvieron en promedio la misma presión arterial final, estos resultados implican que el grupo 1shSCR presentó una disminución de la capacidad contráctil del VI en comparación con el grupo 1shEGFR, que mostró una función contráctil conservada durante todo el período evaluado. Más aún, el hecho de que el corazón en este último grupo haya podido mantener los valores de estos parámetros a pesar de poseer una pared ventricular menor (recordando que el tratamiento disminuyó entre un 7 y un 11\% la HCP), se puede interpretar como un incremento significativo de su capacidad contráctil en comparación con el grupo l-shSCR. 

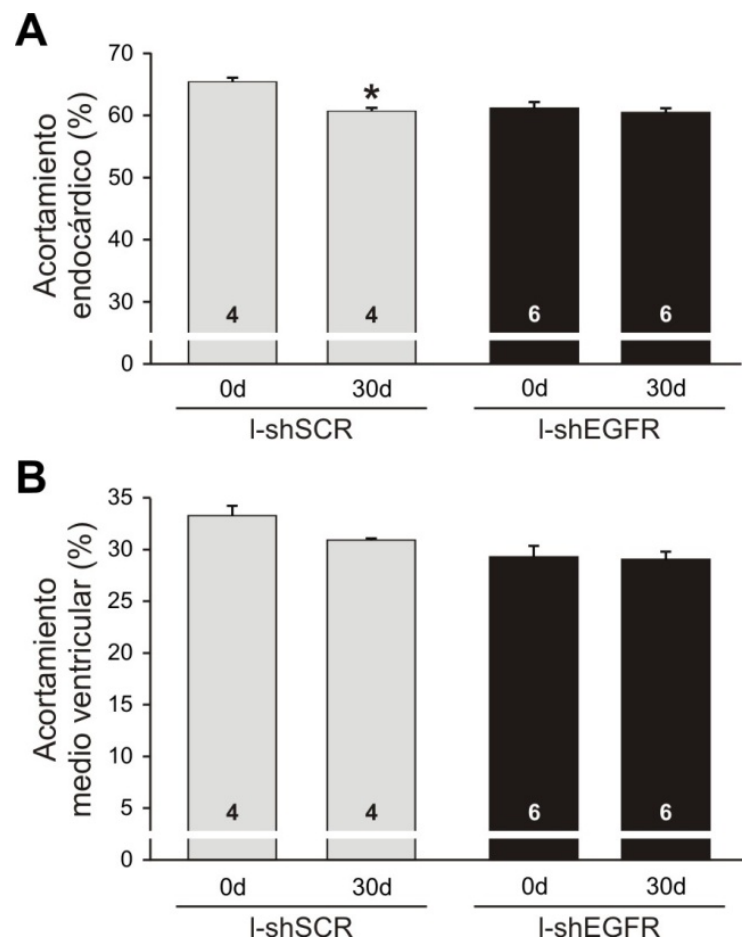

Figura 37. Función cardíaca por ecocardiografía. A. Porcentaje de acortamiento endocárdico. B. Porcentaje de acortamiento medio ventricular. Ambos parámetros fueron evaluados para cada grupo al inicio (0d) y al final (30d) del tratamiento con virus. ${ }^{*} \mathrm{p}<0,05$ vs $0 \mathrm{~d}$.

\section{Estudio de la fibrosis y rigidez miocárdica.}

Otro modo de evaluar la función cardíaca es estudiar la rigidez miocárdica. Se sabe que la HCP cursa con un incremento en el depósito de fibras de colágeno, lo que aumenta la rigidez del miocardio [110], contribuyendo a la alteración de la función diastólica, y finalmente al desarrollo de disfunción sistólica. A fin de evaluar las consecuencias del silenciamiento del EGFR sobre estos parámetros, se determinó el porcentaje de colágeno en el VI de los animales de ambos grupos, y a fin de evaluar la contraparte fisiológica se estudió la rigidez miocárdica en papilares aislados. El colágeno en el VI mostró una tendencia no significativa a la disminución en los animales con el EGFR silenciado (Figura 38A). Por otro lado, en la Figura 38B puede observarse que el grupo inyectado con 1-shEGFR presentó una tendencia a disminuir la rigidez con respecto al grupo control, aunque esta diferencia no fue significativa. 
A

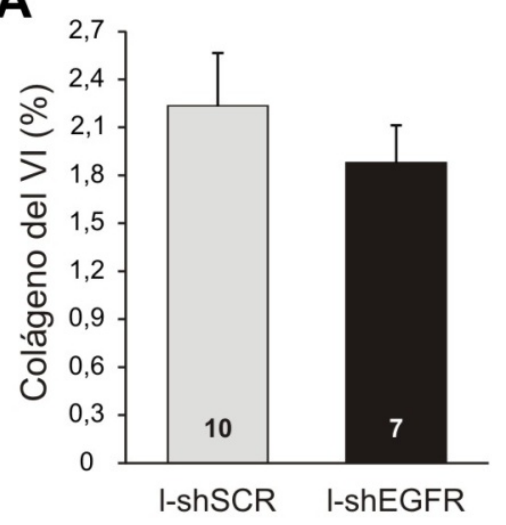

B

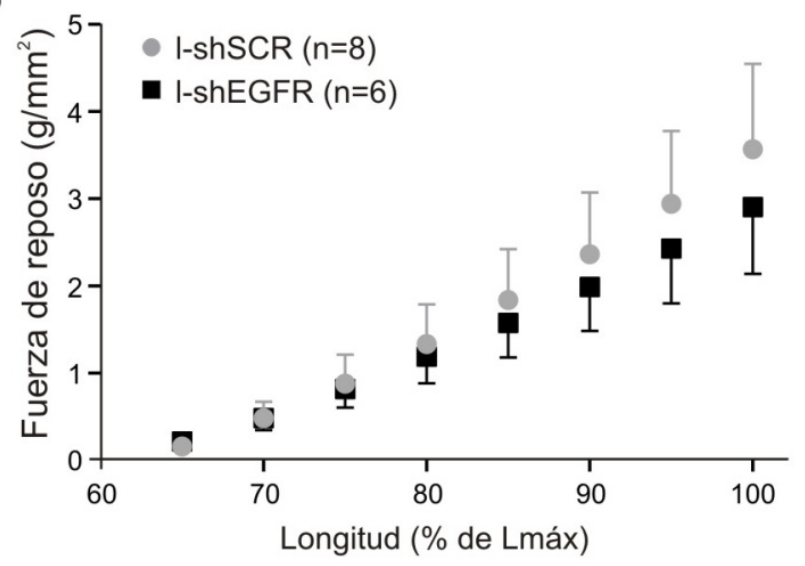

Figura 38. Fibrosis y rigidez miocárdica. A. Porcentaje de colágeno del VI medido por la técnica de pricosirius. Valores promedio por grupo. B. Rigidez miocárdica expresada como fuerza de reposo del músculo papilar en función de la longitud (como porcentaje de la longitud máxima de estiramiento).

\section{Actividad del NHE1 en SHR con silenciamiento del EGFR.}

El NHE1 es una proteína integral de membrana que contribuye con diversos procesos, tales como el crecimiento celular y la proliferación. Es conocido que el miocardio hipertrófico de las ratas SHR presenta un NHE1 hiperactivo [111], lo que implica un incremento en la concentración intracelular de $\mathrm{Na}^{+}$y un consecuente aumento en la entrada de $\mathrm{Ca}^{+2}$ por el transportador NCX, llevando al desarrollo de HCP y falla cardíaca [112, 113]. Existen numerosos trabajos que demuestran que la inhibición farmacológica del NHE1 es beneficiosa, previniendo el remodelado cardíaco en diferentes modelos de HCP e infarto de miocardio [32, 110, 114, 115].

En el apartado 4 de la Sección II del presente trabajo, se mostró que la activación del NHE1 por Ang II requiere de la participación del EGFR, dado que el grupo de ratas Wistar inyectado con 1-shEGFR no mostró un aumento de actividad del NHE1 frente al estímulo de Ang II, mientras que el grupo control sí lo hizo (Figura 25). A fin de evaluar si la disminución de la expresión del EGFR en SHR afecta la actividad del NHE1, se estudió la recuperación de $\mathrm{pH}$ luego de un pulso de amonio en ausencia nominal de bicarbonato, en papilares de ambos grupos experimentales. En estas condiciones, el NHE1 es el único mecanismo activo de recuperación del $\mathrm{pH}$. En la Figura 39A pueden observarse los registros representativos para cada grupo, donde se ve que el grupo tratado con l-shSCR presenta una recuperación significativa del $\mathrm{pH}$ luego del pulso de amonio, mientras que en el grupo tratado con 1-shEGFR la recuperación se ve marcadamente afectada. En la Figura 39B se muestran los resultados promedio por grupo, demostrando una reducción de la actividad del NHE1 por silenciamiento del EGFR. Tomando los resultados en conjunto, y considerando que la hiperactividad del intercambiador en las ratas SHR está descripta como nociva y desencadenante de la HCP que presentan estos animales, se puede inferir que parte de la disminución de la HCP encontrada en el presente trabajo por silenciamiento del EGFR se debería a la disminución de actividad del NHE1 en ausencia del receptor. 


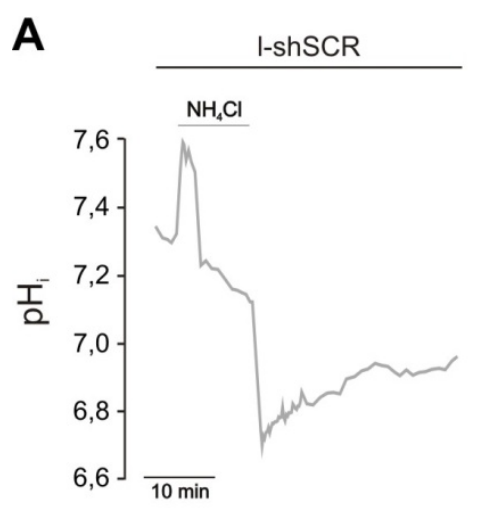

C

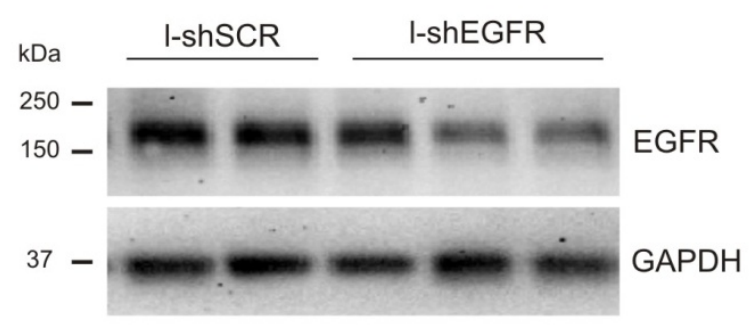

B
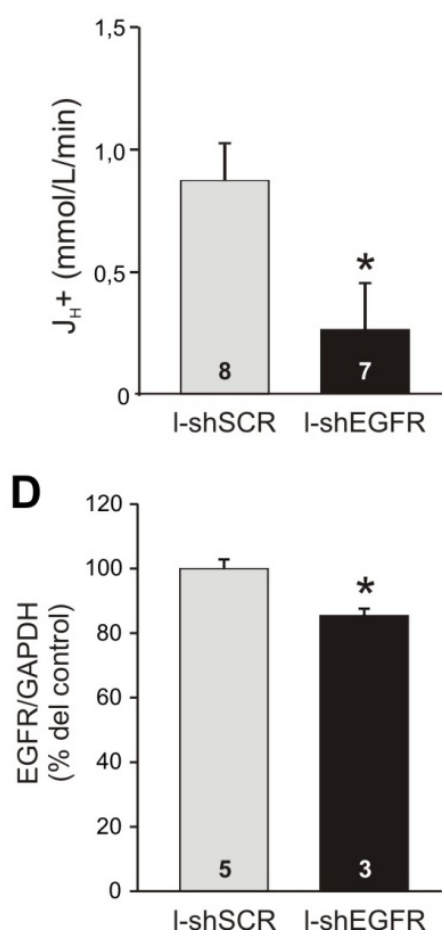

Figura 39. Actividad del NHE1 en papilares de SHR con EGFR silenciado. A. Registros representativos de pulso de amonio y recuperación para los grupos experimentales. B. Resultados promedios por grupo. C. Western blots representativos de homogenato de papilar, mostrando expresión de EGFR. D. Resultados promedios por grupo. ${ }^{*} \mathrm{p}<0,05$ vs 1-shSCR.

En la Figura 39C puede observarse un Western blot representativo realizado en homogenato de papilares, a fin de estudiar el silenciamiento en el músculo además del ya reportado en el VI entero. Como indican los valores promedios por grupo, graficados en la Figura 39D, la expresión del EGFR disminuyó de forma moderada pero significativa ( 20\%) en los papilares provenientes de los corazones inyectados con l-shEGFR, en comparación con aquellos inyectados con 1-shSCR.

\section{Efecto del silenciamiento del EGFR sobre el estrés oxidativo en SHR.}

La generación de ROS es un fenómeno que ocurre normalmente en las células del organismo y que participa en la señalización de procesos fisiológicos. Sin embargo, cuando su producción es excesiva causan daño celular, peroxidación lipídica, y mutagénesis al nivel de ADN que pueden conducir a daño irreversible y muerte celular [116]. Actualmente existen numerosas evidencias que confieren al estrés oxidativo un papel importante en la HCP y en la progresión a insuficiencia cardíaca [117-119]. En este contexto, se midieron diversos indicadores del estrés oxidativo en los grupos experimentales, a fin de estudiar si el silenciamiento del EGFR afectó al estado rédox del corazón de los animales. 
Se estudió la producción basal de anión superóxido en tiritas de VI de ambos grupos, y como puede observarse en la Figura 40A, el silenciamiento del EGFR provocó una disminución en la producción basal de $\mathrm{O}_{2}{ }^{-}$con respecto a la situación control. A su vez se estimó la peroxidación lipídica mediante la cuantificación de T-BARS, encontrándose una disminución significativa en el grupo l-shEGFR con respecto al l-shSCR (Figura 40B).
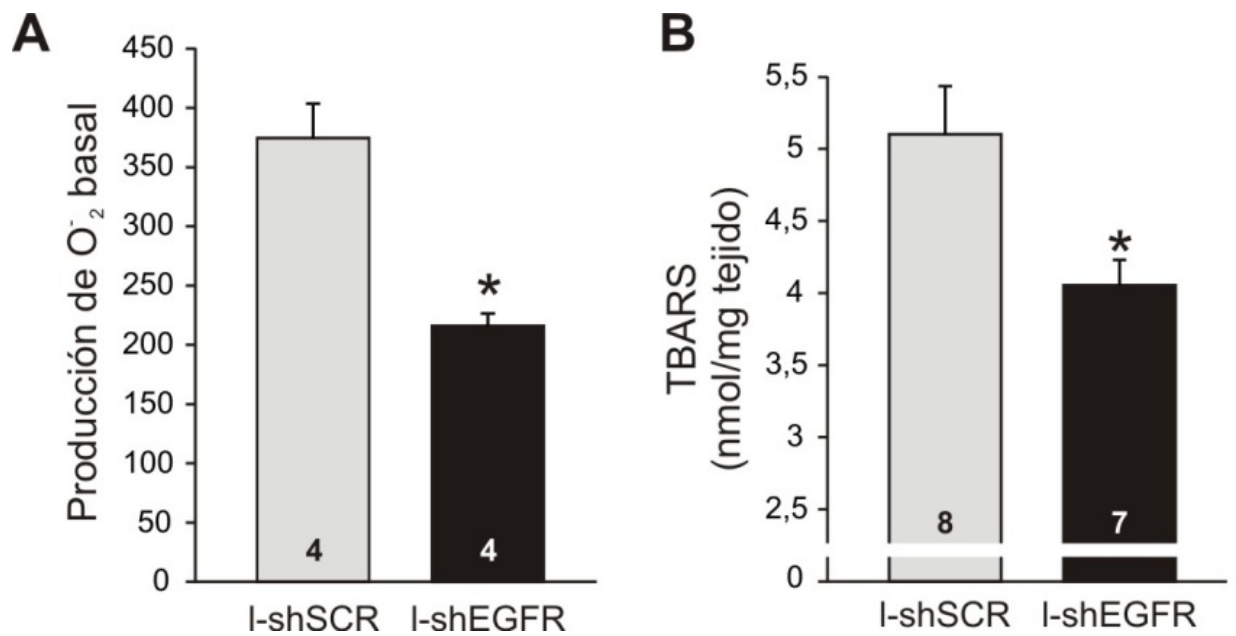

Figura 40. Producción de anión superóxido y T-BARS. A. Medición de producción de $\mathrm{O}_{2}^{-}$en tiritas de VI de ambos grupos. B. Medición de la peroxidación lipídica en homogenato de VI mediante la técnica de T-BARS. * $\mathrm{p}<0,05$ vs control.

Una de las principales fuentes de anión superóxido de la célula son las enzimas NAPDH oxidasas (NOX). Las dos isoformas más expresadas en el corazón son la NOX4, principalmente mitocondrial, y la NOX2 de membrana plasmática (también conocida como gp91). Ambas han sido vinculadas con la generación de HC $[62,120]$, y dada la disponibilidad del anticuerpo en el laboratorio, se evaluó por Western blot de homogenato de VI si la disminución en el superóxido basal encontrada en el grupo l-shEGFR se debía a una disminución en la expresión de gp91. Como puede observarse en la Figura 41, el silenciamiento del EGFR no afectó la expresión de gp91 con respecto al grupo control, sugiriendo que la baja en el estrés oxidativo podría deberse a una disminución en la actividad de la enzima independiente de su expresión, o bien a la inhibición de alguna otra fuente de producción de superóxido involucrada, como podría ser la NOX4. 


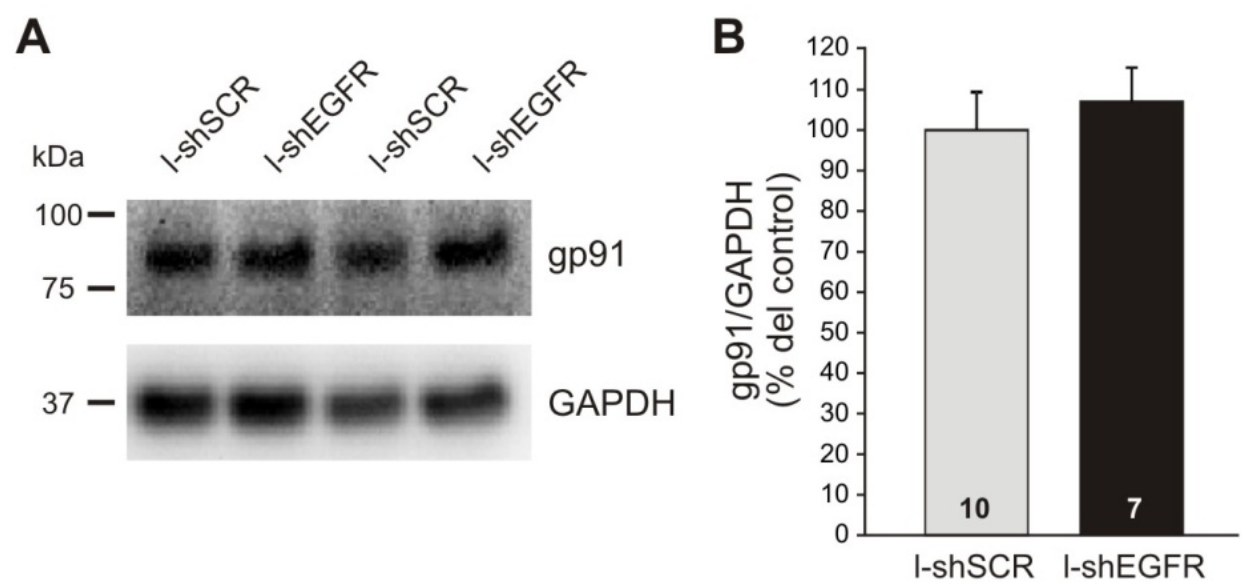

Figura 41. Expresión de gp91. Se trabajó con homogenato de VI. A. Western blot representativos de cada grupo experimental. B. Valores promedio de expresión de gp91. 


$$
\text { DISCUSIÓN }
$$


El estiramiento sostenido del miocardio in vivo es causa de desarrollo de HCP. Por otra parte, el estiramiento miocárdico agudo ex vivo es disparador de la respuesta contráctil conocida como "SFF", que probablemente sea la expresión en preparaciones aisladas del conocido efecto Anrep del corazón entero [121]. Tanto el efecto agudo de adaptar la contractilidad miocárdica a cambios súbitos de las condiciones hemodinámicas, como el efecto patológico disparado por el sostenimiento crónico del estímulo mecánico, compartirían un paso inicial de trans-activación del EGFR por Ang II, mediado por el ligando HB-EGF [122]. La señalización a través del HB-EGF es compleja, dado que activa al EGFR [123] y al ErbB4 [124] de manera directa, pero también puede activar al ErbB2 y al ErbB3 indirectamente por heterodimerización. La activación normal del ErbB4 por el HB-EGF es de hecho esencial para el corazón adulto, habiéndose demostrado que el ErbB4 presenta una fosforilación basal en el VI de ratones salvajes que desaparece en ratones KO para el HB-EGF [125]. Así mismo estos ratones KO del HB-EGF presentan numerosos defectos cardíacos como cavidades ventriculares dilatadas, función sistólica disminuida y válvulas cardíacas engrosadas [125], fenotipo que coincide con el descripto para ratones KO del ErbB4 [126, 127]. Con todo esto, a fin de discriminar el rol específico del EGFR cardíaco en el desarrollo de HC y SFF sin afectar la actividad del ErbB4, uno de los primeros objetivos del presente trabajo de Tesis fue desarrollar una herramienta capaz de bloquear específicamente al receptor.

La tecnología del RNA de interferencia ofrece un mecanismo de bloqueo específico de secuencia. A partir de la secuencia del RNAi contra el EGFR utilizado por Feng y colaboradores [78], se diseñó un cassette de expresión de un shRNA y se insertó en un vector de transferencia lentiviral. Esto difiere de lo realizado en el trabajo de Feng, donde el siRNA sintético se inyectó directamente en el corazón de las ratas, lográndose un silenciamiento significativo del receptor, pero transitorio, analizándose el efecto a las 48 hs de la inyección. En el diseño experimental utilizado en el presente trabajo de Tesis, la utilización de vectores lentivirales para el transporte de la secuencia codificante del shRNA hacia el interior de la célula y su posterior integración al genoma del hospedador, se debió a que permiten un silenciamiento estable en el tiempo.

Una vez generado el vector silenciador del EGFR con su correspondiente control SCR, se comprobó su efecto inhibitorio "in vitro" sobre la expresión del EGFR (Figura 20), y a continuación se utilizó el virus producido a partir del vector silenciador para explorar si esta capacidad silenciadora se podía reproducir "in vivo", inyectándolo en la pared anterolateral del VI. En el laboratorio contamos con experiencias previas en las cuales ya habíamos silenciado "in vivo" con la misma estrategia a otras moléculas como el NHE1 [83, 128] y el MR [82]. A lo largo de esta Tesis, en los distintos estudios realizados, el control utilizado contra el cual se comparó el efecto del silenciamiento fue mayoritariamente el mismo virus portando una secuencia no silenciadora, el 1shSCR. Solamente se utilizó un control Sham, es decir un grupo en el cual se inyectó únicamente el PBS donde se hizo la suspensión de virus, cuando se realizaron estudios de fluorescencia en el microscopio confocal para evaluar la distribución del virus en el tejido cardíaco (Figura 21). En estos experimentos, los corazones de ambos grupos inyectados con virus (tanto l-shEGFR como lshSCR) presentaron emisión de fluorescencia roja, producto de la expresión de DsRed. El uso de animales Sham en este caso particular permitió descartar la auto-fluorescencia propia del preparado, a fin de considerarla como fondo en los animales tratados. De esta manera pudimos 
concluir para los grupos tratados con virus que la fluorescencia observada era propia de la expresión heteróloga de DsRed. Este tipo de estudio, que permite caracterizar de manera simple el patrón de distribución del virus, fue utilizado también en los trabajos antes mencionados [82, 128]. También hemos mostrado en otros trabajos que la inyección del lentivirus en el corazón no afecta la expresión de la proteína blanco en otros órganos $[82,83]$. En el presente trabajo no se midió expresión de EGFR en otros órganos, pero cabe asumir por lo previamente citado que la expresión del receptor no fue modificada en otros tejidos.

El tratamiento con el 1-shEGFR provocó una disminución significativa de la expresión del EGFR (Figura 22), sin afectar la expresión de los otros miembros de la familia de receptores ErbB en corazón adulto, ErbB2 y ErbB4 (Figura 23), mostrando que el lentivirus l-shEGFR generado es específico contra el EGFR. Esta especificidad del l-shEGFR se contrapone con la inespecificidad del AG1478, uno de los inhibidores tirosina quinasa más utilizados para estudiar la función del receptor. Este fármaco fue ampliamente descripto como inhibidor específico del EGFR con una IC50 = 3 nmol/L [129], y utilizado para bloquear al receptor en células y tejido cardíaco [91, 130] y no cardíaco [131]. Las concentraciones de AG1478 utilizadas en experimentos in vitro están en el rango micromolar, lo cual está muy por encima de la IC50 del EGFR, e incluso supera la IC50 para el ErbB4 (29,6 nmol/L). De hecho, el AG1478 en el rango micromolar ha sido utilizado para inhibir directamente al ErbB4 en líneas celulares tumorales [132] y en células cardíacas [133, 134]. Por lo tanto, la utilización del AG1478 como inhibidor del EGFR durante estudios de función cardíaca puede también afectar la actividad del ErbB4, con consecuencias tanto moleculares como fisiológicas. En este aspecto, la especificidad mostrada por el l-shEGFR constituye una gran ventaja que permite discriminar la contribución de ambos receptores.

Dada la naturaleza invasiva de la intervención con lentivirus, un aspecto clave del presente trabajo era definir si la misma había provocado cambios estructurales y/o funcionales en el miocardio. Mediante registros ecocardiográficos se pudo constatar que al final del tratamiento tanto la función como la morfometría estaban preservadas en ambos grupos experimentales (Tabla 1), indicando que ni la geometría ni la función cardíaca basal habían sido afectadas por el silenciamiento crónico del EGFR. Para caracterizar la función cardíaca se determinó la fracción de acortamiento del miocardio (calculada como se detalla en la Sección "Materiales y Métodos"), arrojando valores cercanos al $60 \%$. Es importante destacar que si bien estos valores difieren respecto de algunos datos obtenidos de la bibliografía donde pueden encontrarse fracciones de acortamiento más bajas (por ejemplo 45\% [135]), son coherentes con reportes previos de nuestro grupo de trabajo en la misma cepa de animales $[32,136]$. Respecto de la estructura del miocardio, vale destacar que en contraste con nuestros resultados que indican que el silenciamiento cardíaco del EGFR no modifica la morfometría y función basal del corazón, ratones KO con inhibición completa del EGFR en células del músculo liso vascular y reducción parcial del receptor en cardiomiocitos, presentan un fenotipo con presión arterial reducida y HC [137]. La diferencia en los resultados puede deberse a la localización de la inhibición, dado que nuestro modelo inhibe al EGFR sólo en corazón, dejando intacta la proteína en los vasos sanguíneos, mientras que en el modelo KO el receptor está anulado por completo en los vasos, lo que explicaría la reducción en la presión arterial dada su participación en la función vasoconstrictora. 
El estiramiento de los músculos papilares en el grupo l-shSCR (Figura 24) muestra una SFF similar a la desarrollada en ratas Wistar sin ningún tratamiento obtenidas en nuestro laboratorio y publicadas en diferentes ocasiones [87, 91, 138]. En este sentido, la falta de comparación con animales Sham podría ser una limitación, pero considerando el conjunto de antecedentes anteriormente presentados, éstos indicarían que el lentivirus por sí mismo no tiene consecuencias funcionales. El análisis de la respuesta al estiramiento en los papilares del grupo l-shEGFR mostró que el silenciamiento del EGFR cancela por completo la SFF (Figura 24). Previamente se había demostrado que el tratamiento con AG1478 $1 \mu \mathrm{M}$ reducía la SFF junto con la activación de distintos componentes de la vía [91], pero como se discutió en párrafos anteriores las concentraciones del inhibidor en ese rango afectan también la actividad del ErbB4, no permitiendo la discriminación particular del aporte de cada receptor al proceso. Una vez más, el hallazgo de la cancelación de la SFF por el silenciamiento específico del EGFR logrado en el presente trabajo de Tesis permite concluir que este receptor es un partícipe necesario de la respuesta contráctil del músculo cardíaco al estiramiento. Es interesante destacar que otro mediador involucrado en este mismo proceso, el NHE1, mostró un aumento de su actividad en músculos papilares aislados por estimulación con Ang II en el grupo l-shSCR, mientras que esa activación no se detectó en el grupo 1-shEGFR (Figura 25). Por el contrario en este grupo se observó una leve disminución en el pHi luego de la estimulación con Ang II. Pese a que en el presente trabajo no se han realizado experimentos adicionales para estudiar la causa de este resultado inesperado, la disminución en el pHi observada podría ser explicada considerando la posible participación del intercambiador aniónico Slc26a6, que es un mecanismo regulatorio acidificante del $\mathrm{pH}_{\mathrm{i}}$ que expulsa aniones $\mathrm{OH}^{-}$ en intercambio con $\mathrm{Cl}^{-}$, y que es inhibido por la proteína quinasa $\mathrm{C}$ (PKC) [139]. Por un lado, es conocido que PKC es responsable del incremento de $\mathrm{pH}_{\mathrm{i}}$ mediado por el NHE1 y disparado por Ang II que se observa luego del estiramiento del miocardio en condiciones libres de bicarbonato [92]. Por otro lado, ha sido demostrado que la activación del EGFR promueve la activación de PKC [140]. Por lo tanto, la Ang II podría disparar la activación de PKC mediada por EGFR en el grupo lshSCR, promoviendo la activación del NHE1 y la inhibición del Slc26a6, y dando como resultado un aumento del $\mathrm{pH}$. En el grupo l-shEGFR, donde la expresión del receptor está disminuida, la falta de activación de PKC impediría la activación del NHE1 y la inhibición del Slc26a6, que al estar activo, mediante una lenta extrusión de equivalentes alcalinos sumado a la producción basal de $\mathrm{H}^{+}$, favorecería la acidificación intracelular observada.

Otro aspecto interesante para discutir en el presente trabajo involucra el estrés oxidativo. El incremento en la producción de ROS está propuesto como un paso temprano en la ruta activada por Ang II durante el estiramiento cardíaco y la HC patológica [122, 141, 142]. Una pequeña concentración de Ang II ( $1 \mathrm{nmol} / \mathrm{L})$ que es capaz de reproducir en magnitud el aumento de fuerza contráctil observado durante la segunda fase de fuerza, induce de manera secuencial un incremento en la producción de ROS, activación de quinasas ERK1/2 y p90RSK, y fosforilación y activación del NHE1 [93, 143]. Esta vía facilita la entrada de sodio a la célula, y la consecuente entrada de calcio. En el presente trabajo de Tesis se ha mostrado que la estimulación aguda de muestras de VI con reducción parcial del EGFR mediante Ang II o EGF, no provoca un incremento de la producción de anión superóxido (Figura 26), indicando que el receptor es necesario en la vinculación de la señal extracelular con el aumento de ROS. Por otra parte, la reducción crónica de 
la expresión del EGFR no indujo ningún cambio en el estado redox basal del tejido cardíaco, ni en la expresión y actividad de la NOX2 (Figura 27). Esto permite concluir que la inhibición de la producción de $\mathrm{O}_{2}-$ observada en la Figura 26 en el grupo 1-shEGFR no se debe a una disminución en la actividad basal de las fuentes de producción de ROS, sino a una inhibición de la señalización que dispara Ang II y transactiva al EGFR. En contraste con estos resultados, los ratones KO de EGFR en células del músculo liso vascular, que además cuentan con una reducción parcial de su expresión en cardiomiocitos, muestran una producción basal de ROS incrementada [137]. Esta contradicción posiblemente se deba a diferencias en cuanto a la localización del bloqueo, que como se discutió anteriormente provocaría que los ratones $\mathrm{KO}$ presenten hipertrofia mientras que nuestras ratas con 1-shEGFR no (Tabla 1). Vale destacar que según concluyen los autores, en el mencionado modelo $\mathrm{KO}$ la hipertrofia generada provocaría el aumento de ROS como consecuencia de un aumento en la expresión de la NOX4. En nuestro modelo no hemos medido expresión de la NOX4, por lo que no se puede descartar que esté afectada, pero sí determinamos la expresión de la subunidad gp91 de la NOX2, que no se vio alterada por el silenciamiento del EGFR (Figura 27).

Siguiendo la secuencia de eventos que se inicia con la trans-activación del EGFR por Ang II, la producción de ROS lleva a la activación de quinasas redox-sensibles, como ERK1/2 y p90RSK. Se sabe que la quinasa ERK1/2 está influenciada también por la señalización proveniente del ErbB4. Ha sido demostrado que la administración de HB-EGF a células HEK 293T transfectadas con el ErbB4 induce la fosforilación de ERK1/2, y se obtiene un grado de fosforilación similar cuando se estimula al sistema con neuregulina 1 (NRG1, un agonista específico del ErbB4) [134]. La administración in vitro de NRG1 a células PC12 (provenientes de médula suprarrenal) o a cardiomiocitos adultos estimula la fosforilación de ERK1/2, la cual es inhibida en forma dosis dependiente con AG1478. Los resultados del presente trabajo muestran que la inhibición específica del EGFR cardíaco es suficiente para evitar la fosforilación de ERK1/2 por Ang II (Figura 29), dejando de lado una potencial contribución del ErbB4. Estos resultados son similares a los obtenidos por otros autores en ratas tratadas con Ang II y un oligonucleótido anti sentido contra el EGFR [30], así como también coinciden con los publicados recientemente en células H9c2 [47]. La fosforilación de p90RSK por Ang II y por EGF también fue abolida por silenciamiento del EGFR (Figura 30). La relación entre esta quinasa y el receptor no está clara, menos aún en tejido cardíaco. Se sabe que neuronas hipotalámicas estimuladas con EGF y GnRH (hormona liberadora de gonadotrofina) muestran un aumento de la fosforilación de p90RSK que se bloquea por inhibición con AG1478 [144]. Por su parte la radiación UV induce en fibroblastos la activación de EGFR y la fosforilación de p90RSK, mientras que en fibroblastos EGFR-/- esa fosforilación se cancela [145]. En tejido cardíaco se ha estudiado la fosforilación de p90RSK por aldosterona [146] y ET-1 [147], y en ambos casos la activación se cancela por inhibición con AG1478. El presente trabajo de Tesis evalúa por primera vez el efecto de la inhibición del EGFR en la activación de p90RSK por Ang II en tejido cardíaco, demostrando que la trans-activación del receptor por Ang II es necesaria para la activación de la quinasa.

Uno de los principales objetivos planteados en el plan de Tesis fue estudiar el rol del EGFR en el desarrollo de HCP. A fin de cumplir con dicho objetivo, y por motivos que ya se han detallado en la Sección "Resultados", nos vimos obligados a re-direccionar nuestros experimentos 
respecto a lo originalmente planteado, moviéndonos hacia un modelo genético de HC por hipertensión arterial como lo es el de las ratas SHR (con el cual nuestro grupo tiene vasta experiencia). En tal sentido, se inyectó l-shEGFR o su correspondiente control en el miocardio de SHR para silenciar al receptor y se determinaron los efectos de dicha intervención al cabo de 30 días. La distribución de los virus en los VI de estos animales fue en parches (Figura 32), tal y como lo había sido para los animales Wistar utilizados en la Sección II. En este caso tampoco se utilizó un grupo Sham más que para los experimentos de microscopía confocal, pero se ha demostrado previamente que la inyección de un lentivirus control l-shSCR, no produce cambios en la anatomía o función cardíaca respecto de los valores observados en los animales Sham [83]. La reducción en la expresión del EGFR alcanzada en el grupo l-shEGFR fue de $\sim 40 \%$ con respecto al grupo l-shSCR (Figura 33), sin afectar la expresión de los otros receptores ErbB cardíacos (Figura 34).

Estudios previos en ratas SHR revelaron que la expresión del EGFR es mayor que en las ratas normotensas WKY [148] (lo cual limita su utilidad como control), y que ésta se reduce con la edad de los animales [45]. Por esta razón se inyectaron animales a las 12 semanas y se sacrificaron a las 16 semanas. Como se dijo antes, la expresión del EGFR se redujo $40 \%$ de manera similar a lo reportado por Kagishama y colaboradores con DNA anti sentido [45]. Es necesario aclarar que la reducción es menor a la que encontramos previamente en animales Wistar (Sección II) o a la descripta para otras proteínas [83, 128]. Aunque lamentablemente no contamos con elementos que nos permitan brindar una explicación clara acerca de esta discrepancia, es importante destacar que la disminución de la expresión del receptor fue suficiente para disminuir de manera significativa la HC (medida a través de los cocientes PVI/PR y PVI/LT, Figura 35). El análisis de la bibliografía disponible revela un único antecedente de evaluación de HC por inhibición del EGFR en ratas SHR [45], donde se muestra que la administración por 8 semanas de DNA anti sentido animales de 14 semanas de edad no redujo significativamente la HCP respecto de los inyectados con DNA sentido. En el mismo trabajo, al utilizar animales jóvenes, la disminución de la expresión del EGFR estuvo asociada a una reducción de la $\mathrm{HCP}$, tal y como encontramos en el presente trabajo. Cabe destacar sin embargo que la inhibición realizada en ese caso fue sistémica, implicando a los vasos y disminuyendo la presión arterial. Por el contrario, en la presente tesis, la disminución de la HC es producto de un bloqueo del EGFR acotado al corazón, mientras que la presión arterial se mantuvo inalterada durante el tratamiento (Figura 36).

Es necesario destacar que para caracterizar la posible participación del EGFR en la HCP de ratas SHR usamos como control al animal hipertrófico inyectado con 1-shSCR, lo cual no permite determinar si la HCP se revirtió plenamente al no haber comparación contra un control normotrófico. Aunque esto puede ser considerado una flaqueza del trabajo, el hecho de haber probado eficazmente la participación del EGFR en el desarrollo de HCP es per se un hallazgo sumamente importante, quedando por delante el interrogante de si el bloqueo es capaz de normalizar el miocardio. Para tal fin, será clave definir un adecuado diseño experimental que minimice las posibilidades de arribar a conclusiones erróneas, dado que las ratas WKY normotensas (contra las cuales se han comparado históricamente a las SHR) no parecieran ser un control adecuado. En tal sentido, es necesario remarcar que Kikuchi y colaboradores probaron que 
las WKY presentan un fenotipo molecular para HB-EGF y EGFR distinto al de las ratas SHR [148], y que posiblemente las discrepancias se puedan extender a otras moléculas tanto del eje ReninaAngiotensina-Aldosterona, como del eje simpático. Sumado a esto, resultados previos de nuestro grupo de trabajo han demostrado que las ratas WKY presentan hipertrofia cardíaca independientemente de los niveles de presión arterial [136].

Diversos grupos han estudiado la prevención de la HCP por inhibición del EGFR en animales sometidos a distintos estímulos pro-hipertróficos. Por un lado, ratones transgénicos que expresan una variante del receptor AT1 con una mutación en el residuo de trans-activación del EGFR, no desarrollan HCP frente al estímulo con Ang II [14]. En la misma línea, ratones tratados con bombas de Ang II y un inhibidor farmacológico del EGFR (AG542) de modo sistémico no desarrollaron HCP [47]. Experimentos con bombas infundiendo Ang II también fueron utilizadas en ratas, en las cuales la elevación de la presión arterial y el aumento de la HCP se anularon mediante administración sistémica de un anti sentido contra el EGFR [30]. Vale aclarar que si bien en este último caso la inhibición fue específica para el EGFR sin afectar la expresión del ErbB2, el silenciamiento sistémico impide discriminar el aporte específico del receptor cardíaco. Otro compuesto utilizado para inhibir la activación del EGFR en ratones fue la silibinina (un compuesto orgánico extraído de plantas del género Silybum con propiedades anti tumorales y anti inflamatorias que se utiliza para el tratamiento de enfermedades hepáticas). Los animales pre tratados con este inhibidor y sometidos a bandeo aórtico, no desarrollaron HCP en comparación con los grupos con bandeo y tratamiento con vehículo [149]. Si bien se demuestra que el agregado de silibinina inhibe la fosforilación del EGFR producida por el bandeo aórtico, no queda claro que la inhibición del receptor sea específica, dado que el compuesto orgánico ha sido utilizado para inhibir otros blancos moleculares [150,151]. Es importante destacar que más allá de las similitudes y/o las discrepancias que se puedan detectar entre los distintos grupos experimentales que han tratado el tema, una diferencia fundamental entre los trabajos enumerados y el presente trabajo de Tesis doctoral, es que los primeros evalúan prevención de HCP (el bloqueo del receptor es previo a la generación de la patología), mientras que en nuestro trabajo evaluamos regresión de la $\mathrm{HCP}$, dado que el tratamiento con el lentivirus silenciador del EGFR revierte al menos parcialmente el cuadro de hipertrofia ya establecida de las SHR. De todos modos, en conjunto, tanto los trabajos citados como el presente trabajo, sugieren un papel clave del EGFR en el proceso de desarrollo de la HCP.

El estudio de la fibrosis y de la rigidez miocárdica, mostró una tendencia no significativa a la disminución en ambos parámetros en el grupo l-shEGFR con respecto al 1-shSCR (Figura 38). Este resultado está dentro de lo esperable, dado que experimentos previos de nuestro grupo inhibiendo al NHE1 con cariporide en ratas SHR han demostrado que los cambios en la fibrosis, y por ende en la rigidez miocárdica, requieren tiempos de tratamiento mayores al utilizado en el presente trabajo [152]. En tal sentido, la inhibición del NHE1 debió sostenerse por al menos 2 meses para observar una disminución clara del colágeno y de los valores séricos de PIP (un marcador de la síntesis de colágeno tipo I), mientras que fue necesario llegar a los 3 meses de tratamiento para que dicha disminución se refleje en una menor rigidez miocárdica, siendo que al 
mes de tratamiento la HC (estimada mediante el índice PVI/PR y el área de sección de los cardiomiocitos) ya presentaba valores similares a los de los controles normotróficos [152]. En otro modelo de hipertrofia, generada por sobre-expresión de los receptores adrenérgicos $\beta 1$, la regresión de la fibrosis fue observada recién luego de 5 meses de inhibición del NHE1 [115].

Otro hallazgo importante en el presente estudio fue que las ratas SHR inyectadas con 1shEGFR presentaron una disminución significativa de la actividad del NHE1, en comparación con las ratas 1-shSCR (Figura 39). Tanto la medida de la expresión total del intercambiador como la de su fosforilación son actividades pendientes del presente trabajo de Tesis (ver la Sección “Proyectos a futuro"), a fin de comprobar que la bajada en la actividad encontrada no se deba a una bajada en la expresión total de la proteína. No hay antecedentes de evaluación de actividad del NHE1 en ausencia de EGFR en un modelo de hipertrofia, pero el antecedente más próximo realizado inhibiendo al EGFR con AG1478 en ratas Wistar muestra que el bloqueo del receptor inhibe la fosforilación del NHE1 en el residuo Ser703, sin modificar su expresión [91]. Una posible explicación a la disminución de la actividad del NHE1 podría ser una disminución en la activación de las quinasas redox-sensibles ERK1/2 y p90RSK, que lo activan por fosforilación. Si bien tampoco medimos la fosforilación de estas quinasas, sí demostramos que el grupo l-shEGFR presenta una disminución del estrés oxidativo medido a través de la producción de anión superóxido y de la cuantificación de T-BARS (Figura 40). Dado que las quinasas que activan al NHE1 son sensibles al estrés oxidativo, podríamos inferir que la bajada de las ROS disminuye la fosforilación de ERK1/2 y p90RSK, y esto a su vez explicaría la disminución en la actividad del intercambiador. Es importante resaltar sin embargo, que la disminución de la producción de ROS por inhibición del EGFR mostrada en el presente trabajo se contrapone con el aumento de estrés oxidativo que muestra el modelo KO del EGFR previamente discutido [153]. En ese modelo, la falta total del EGFR en vasos y parcial en cardiomiocitos provoca un aumento de la producción basal de ROS, que los autores atribuyen a un aumento en el RNAm de la NOX4. En la presente Tesis se demostró que el silenciamiento específico en corazón del EGFR no modifica la expresión de la NOX2 (Figura 41), y se propone como actividades futuras medir su actividad, así como también la expresión de NOX4. 
CONCLUSIONES 
Las conclusiones principales del presente trabajo son las siguientes:

1. Se desarrolló un lentivirus de tercera generación portador de una secuencia shRNA capaz de silenciar de manera específica al EGFR. Tanto su funcionalidad como su especificidad se comprobaron en modelos in vitro e in vivo.

2. El EGFR es necesario para la generación de la SFF al estiramiento cardíaco. Mediante el bloqueo específico del receptor se evidenció una disminución en la actividad del NHE1 y una cancelación de la SFF.

3. El estrés oxidativo generado por el estiramiento se anula por el silenciamiento del EGFR. Tanto la generación de ROS como la activación de las quinasas redox- sensibles necesita de la presencia del EGFR para suceder, y el bloqueo in vivo del receptor lleva a la cancelación de ambos fenómenos.

4. El silenciamiento del EGFR reduce el progreso a la HCP en ratas SHR. Tanto los parámetros morfométricos como los ecocardiográficos se vieron mejorados en los animales con 1-shEGFR, que presentaron además una menor área de los cardiomiocitos y una actividad del NHE1 disminuída.

5. El estrés oxidativo propio del cuadro de HCP en ratas SHR se reduce por silenciamiento del EGFR. Los animales con l-shEGFR mostraron menor producción de anión superóxido y menor grado de peroxidación lipídica que los animales controles.

En conclusión, el EGFR es un receptor necesario tanto para la SFF producto del estiramiento del músculo cardíaco, como para la HCP producto de la hipertensión. En ambos procesos, el bloqueo del receptor reduce el estrés oxidativo de manera significativa, anulando la SFF y mejorando la progresión a $\mathrm{HCP}$, respectivamente. 


\section{CONCLUSIÓN GRÁFICA}

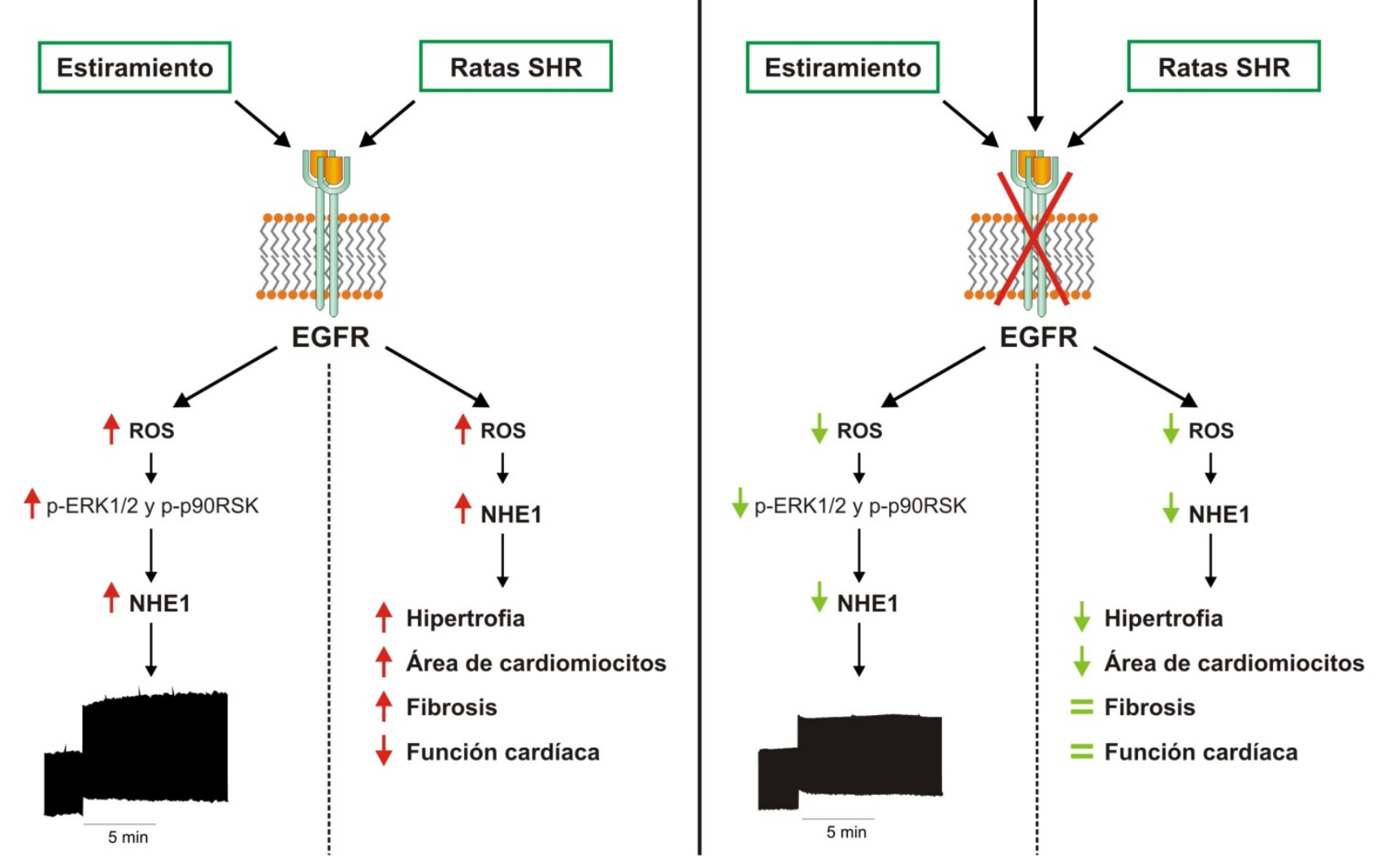




\section{PROYECTOS A FUTURO}

A fin de completar los resultados expuestos en la Sección III del presente trabajo de tesis, en el modelo de ratas SHR inyectadas con 1-shEGFR, se propone lo siguiente:

- Evaluar por Western blot la expresión de marcadores característicos de hipertrofia como ANP, BNP y $\beta$-MHC en VI de ambos grupos, a fin de complementar los experimentos de medida de HC por balanza.

- Evaluar la expresión y activación medida por fosforilación de las quinasas sensibles a ROS p90 y ERK1/2, para completar el eje ROS-quinasas-NHE1.

- Medir la expresión del NHE1, a fin de evaluar si el tratamiento crónico con el 1shEGFR no modificó la expresión del intercambiador, y medir también su activación por fosforilación, para complementar los experimentos de pulso de amonio.

- Medir actividad de NOX2 por el método de lucigenina como se realizó para las ratas Wistar de la Sección II, y estudiar la expresión de las subunidades regulatorias de la enzima, como p47phox y p22 phox, todo a fin de estudiar el origen de la disminución de la producción de ROS encontrada en el grupo l-shEGFR.

- Estudiar la expresión de la NOX4, dado que es también una fuente de producción de ROS vinculada a la HCP.

Como continuación del proyecto se propuso en la presentación a Beca Posdoctoral estudiar la contribución del ErbB2 y ErbB4 a la hipertrofia cardíaca patológica mediante silenciamiento génico de cada uno de ellos con los shRNA correspondientes. Por otro lado se propuso estudiar en detalle el fenómeno de dimerización en la trans-activación por Ang II, a fin de evaluar qué dímeros son los que se forman. Para ello contamos en el laboratorio con la línea celular cardíaca H9c2, que presenta las facilidades prácticas de una línea celular, y a la vez ofrece un modelo de cardiomiocito. Según los resultados obtenidos in vitro se estudiará el fenómeno in vivo. 
REFERENCIAS 


\section{REFERENCIAS}

1. Olayioye, M.A., et al., The ErbB signaling network: receptor heterodimerization in development and cancer. EMBO J, 2000. 19(13): p. 3159-67.

2. Ogiso, H., et al., Crystal structure of the complex of human epidermal growth factor and receptor extracellular domains. Cell, 2002. 110(6): p. 775-87.

3. Fuller, S.J., K. Sivarajah, and P.H. Sugden, ErbB receptors, their ligands, and the consequences of their activation and inhibition in the myocardium. J Mol Cell Cardiol, 2008. 44(5): p. 831-54.

4. Burgess, A.W., et al., An open-and-shut case? Recent insights into the activation of EGF/ErbB receptors. Mol Cell, 2003. 12(3): p. 541-52.

5. Jorissen, R.N., et al., Epidermal growth factor receptor: mechanisms of activation and signalling. Exp Cell Res, 2003. 284(1): p. 31-53.

6. Stamos, J., M.X. Sliwkowski, and C. Eigenbrot, Structure of the epidermal growth factor receptor kinase domain alone and in complex with a 4-anilinoquinazoline inhibitor. J Biol Chem, 2002. 277(48): p. 46265-72.

7. Zhang, X., et al., An allosteric mechanism for activation of the kinase domain of epidermal growth factor receptor. Cell, 2006. 125(6): p. 1137-49.

8. Niculescu-Duvaz, D., et al., The EGF receptor Hokey-Cokey. Cancer Cell, 2007. 11(3): p. 209-11.

9. Jones, R.B., et al., A quantitative protein interaction network for the ErbB receptors using protein microarrays. Nature, 2006. 439(7073): p. 168-74.

10. Heitzler, D., et al., Towards a systems biology approach of-G protein-coupled receptor signalling: challenges and expectations. C R Biol, 2009. 332(11): p. 947-57.

11. Daub, H., et al., Role of transactivation of the EGF receptor in signalling by G-proteincoupled receptors. Nature, 1996. 379(6565): p. 557-60.

12. Fernandez-Martinez, A.B. and F.J. Lucio-Cazana, Transactivation of EGFR by prostaglandin E2 receptors: a nuclear story? Cell Mol Life Sci, 2015. 72(11): p. 2187-98.

13. Beltowski, J. and A. Jazmroz-Wisniewska, Transactivation of ErbB receptors by leptin in the cardiovascular system: mechanisms, consequences and target for therapy. Curr Pharm Des, 2014. 20(4): p. 616-24.

14. Zhai, P., An Angiotensin II Type 1 Receptor Mutant Lacking Epidermal Growth Factor Receptor Transactivation Does Not Induce Angiotensin II-Mediated Cardiac Hypertrophy. Circulation Research, 2006. 99(5): p. 528-536.

15. Bokemeyer, D., U. Schmitz, and H.J. Kramer, Angiotensin II-induced growth of vascular smooth muscle cells requires an Src-dependent activation of the epidermal growth factor receptor. Kidney Int, 2000. 58(2): p. 549-58.

16. Prenzel, N., et al., EGF receptor transactivation by G-protein-coupled receptors requires metalloproteinase cleavage of proHB-EGF. Nature, 1999. 402(6764): p. 884-8.

17. Massague, J. and A. Pandiella, Membrane-anchored growth factors. Annu Rev Biochem, 1993. 62: p. 515-41.

18. Singh, A.B. and R.C. Harris, Autocrine, paracrine and juxtacrine signaling by EGFR ligands. Cell Signal, 2005. 17(10): p. 1183-93.

19. Sundaresan, S., et al., Biological response to ErbB ligands in nontransformed cell lines correlates with a specific pattern of receptor expression. Endocrinology, 1998. 139(12): p. 4756-64.

20. Zhao, Y.Y., et al., Neuregulins promote survival and growth of cardiac myocytes. Persistence of ErbB2 and ErbB4 expression in neonatal and adult ventricular myocytes. J Biol Chem, 1998. 273(17): p. 10261-9.

21. Perrella, M.A., et al., Regulation of heparin-binding epidermal growth factor-like growth factor $m R N A$ levels by hypertrophic stimuli in neonatal and adult rat cardiac myocytes. $\mathrm{J}$ Biol Chem, 1994. 269(43): p. 27045-50. 
22. Zhao, Y.Y., et al., Neuregulin signaling in the heart. Dynamic targeting of erbB4 to caveolar microdomains in cardiac myocytes. Circ Res, 1999. 84(12): p. 1380-7.

23. Ueda, H., et al., Neuregulin receptor ErbB2 localization at T-tubule in cardiac and skeletal muscle. J Histochem Cytochem, 2005. 53(1): p. 87-91.

24. Karmazyn, M., et al., The myocardial $\mathrm{Na}(+)-H(+)$ exchange: structure, regulation, and its role in heart disease. Circ Res, 1999. 85(9): p. 777-86.

25. Cingolani, H.E. and I.L. Ennis, Sodium-hydrogen exchanger, cardiac overload, and myocardial hypertrophy. Circulation, 2007. 115(9): p. 1090-100.

26. Cingolani, H.E., et al., Role of autocrine/paracrine mechanisms in response to myocardial strain. Pflugers Arch, 2011. 462(1): p. 29-38.

27. Dotsenko, S.Y., A.A. Tokarenko, and Tokarenko, II, Regression of left ventricular hypertrophy in patients with essential hypertension and long-term therapy with losartan. Lik Sprava, 2015(7-8): p. 17-21.

28. Ito, H., et al., Endothelin ETA receptor antagonist blocks cardiac hypertrophy provoked by hemodynamic overload. Circulation, 1994. 89(5): p. 2198-203.

29. Martin-Fernandez, B., et al., Spironolactone prevents alterations associated with cardiac hypertrophy produced by isoproterenol in rats: involvement of serum- and glucocorticoidregulated kinase type 1. Exp Physiol, 2012. 97(6): p. 710-8.

30. Kagiyama, S., et al., Angiotensin II-Induced Cardiac Hypertrophy and Hypertension Are Attenuated by Epidermal Growth Factor Receptor Antisense. Circulation, 2002. 106(8): p. 909-912.

31. Sabri, A., H.H. Hughie, and P.A. Lucchesi, Regulation of hypertrophic and apoptotic signaling pathways by reactive oxygen species in cardiac myocytes. Antioxid Redox Signal, 2003. 5(6): p. 731-40.

32. Ennis, I.L., et al., Regression of isoproterenol-induced cardiac hypertrophy by $\mathrm{Na}+\mathrm{H}+$ exchanger inhibition. Hypertension, 2003. 41(6): p. 1324-9.

33. http://www.who.int/mediacentre/factsheets. 2017.

34. Riley, L. and M. Cowan, Noncommunicable diseases. Country Profile 2014, 2014, World Health Organization.

35. Frohlich, E.D., A. Gonzalez, and J. Diez, Hypertensive left ventricular hypertrophy risk: beyond adaptive cardiomyocytic hypertrophy. J Hypertens, 2011. 29(1): p. 17-26.

36. de Simone, G., et al., Left ventricular mass predicts heart failure not related to previous myocardial infarction: the Cardiovascular Health Study. Eur Heart J, 2008. 29(6): p. 741-7.

37. Schillaci, G., et al., Continuous relation between left ventricular mass and cardiovascular risk in essential hypertension. Hypertension, 2000. 35(2): p. 580-6.

38. Brown, D.W., W.H. Giles, and J.B. Croft, Left ventricular hypertrophy as a predictor of coronary heart disease mortality and the effect of hypertension. Am Heart J, 2000. 140(6): p. 848-56.

39. East, M.A., et al., The influence of left ventricular hypertrophy on survival in patients with coronary artery disease: do race and gender matter? J Am Coll Cardiol, 2003. 41(6): p. 949-54.

40. Ghali, J.K., Y. Liao, and R.S. Cooper, Influence of left ventricular geometric patterns on prognosis in patients with or without coronary artery disease. J Am Coll Cardiol, 1998. 31(7): p. 1635-40.

41. Yamamoto, S., et al., On the nature of cell death during remodeling of hypertrophied human myocardium. J Mol Cell Cardiol, 2000. 32(1): p. 161-75.

42. Akki, A., K. Smith, and A.M. Seymour, Compensated cardiac hypertrophy is characterised by a decline in palmitate oxidation. Mol Cell Biochem, 2008. 311(1-2): p. 215-24.

43. Wende, A.R. and E.D. Abel, Lipotoxicity in the heart. Biochim Biophys Acta, 2010. 1801(3): p. 311-9.

44. Barry, S.P., S.M. Davidson, and P.A. Townsend, Molecular regulation of cardiac hypertrophy. Int J Biochem Cell Biol, 2008. 40(10): p. 2023-39. 
45. Kagiyama, S., et al., Antisense to Epidermal Growth Factor Receptor Prevents the Development of Left Ventricular Hypertrophy. Hypertension, 2002. 41(3): p. 824-829.

46. Cai, J., et al., Targeted expression of receptor-associated late transducer inhibits maladaptive hypertrophy via blocking epidermal growth factor receptor signaling. Hypertension, 2009. 53(3): p. 539-48.

47. Peng, K., et al., Novel EGFR inhibitors attenuate cardiac hypertrophy induced by angiotensin II. J Cell Mol Med, 2016. 20(3): p. 482-94.

48. Smith, N.J., et al., Determination of the Exact Molecular Requirements for Type 1 Angiotensin Receptor Epidermal Growth Factor Receptor Transactivation and Cardiomyocyte Hypertrophy. Hypertension, 2011. 57(5): p. 973-980.

49. Sawyer, D.B., et al., Role of oxidative stress in myocardial hypertrophy and failure. J Mol Cell Cardiol, 2002. 34(4): p. 379-88.

50. Nordberg, J. and E.S. Arner, Reactive oxygen species, antioxidants, and the mammalian thioredoxin system. Free Radic Biol Med, 2001. 31(11): p. 1287-312.

51. Kwon, S.H., et al., H(2)O(2) regulates cardiac myocyte phenotype via concentrationdependent activation of distinct kinase pathways. J Mol Cell Cardiol, 2003. 35(6): p. 615-21.

52. Delbosc, S., et al., Simvastatin prevents angiotensin II-induced cardiac alteration and oxidative stress. Hypertension, 2002. 40(2): p. 142-7.

53. Amin, J.K., et al., Reactive oxygen species mediate alpha-adrenergic receptor-stimulated hypertrophy in adult rat ventricular myocytes. J Mol Cell Cardiol, 2001. 33(1): p. 131-9.

54. Cheng, T.H., et al., Involvement of reactive oxygen species in angiotensin II-induced endothelin-1 gene expression in rat cardiac fibroblasts. J Am Coll Cardiol, 2003. 42(10): p. 1845-54.

55. Siwik, D.A., P.J. Pagano, and W.S. Colucci, Oxidative stress regulates collagen synthesis and matrix metalloproteinase activity in cardiac fibroblasts. Am J Physiol Cell Physiol, 2001. 280(1): p. C53-60.

56. Zima, A.V. and L.A. Blatter, Redox regulation of cardiac calcium channels and transporters. Cardiovasc Res, 2006. 71(2): p. 310-21.

57. Murdoch, C.E., et al., NADPH oxidase-dependent redox signalling in cardiac hypertrophy, remodelling and failure. Cardiovasc Res, 2006. 71(2): p. 208-15.

58. Li, J.M., et al., Essential role of the NADPH oxidase subunit p47(phox) in endothelial cell superoxide production in response to phorbol ester and tumor necrosis factor-alpha. Circ Res, 2002. 90(2): p. 143-50.

59. Xiao, L., et al., Role of reactive oxygen species and $N A D(P) H$ oxidase in alpha(1)adrenoceptor signaling in adult rat cardiac myocytes. Am J Physiol Cell Physiol, 2002. 282(4): p. C926-34.

60. Li, J.M., et al., Activation of NADPH oxidase during progression of cardiac hypertrophy to failure. Hypertension, 2002. 40(4): p. 477-84.

61. Heymes, C., et al., Increased myocardial NADPH oxidase activity in human heart failure. J Am Coll Cardiol, 2003. 41(12): p. 2164-71.

62. Bendall, J.K., et al., Pivotal role of a gp91(phox)-containing NADPH oxidase in angiotensin II-induced cardiac hypertrophy in mice. Circulation, 2002. 105(3): p. 293-6.

63. Looi, Y.H., et al., Involvement of Nox2 NADPH oxidase in adverse cardiac remodeling after myocardial infarction. Hypertension, 2008. 51(2): p. 319-25.

64. Maytin, M., et al., Pressure overload-induced myocardial hypertrophy in mice does not require gp91phox. Circulation, 2004. 109(9): p. 1168-71.

65. Fire, A., et al., Potent and specific genetic interference by double-stranded RNA in Caenorhabditis elegans. Nature, 1998. 391(6669): p. 806-11.

66. Aigner, A., Delivery Systems for the Direct Application of siRNAs to Induce RNA Interference (RNAi) In Vivo. Journal of Biomedicine and Biotechnology, 2006. 2006: p. 115.

67. Hammond, S.M., et al., An RNA-directed nuclease mediates post-transcriptional gene 
silencing in Drosophila cells. Nature, 2000. 404(6775): p. 293-6.

68. Nykanen, A., B. Haley, and P.D. Zamore, ATP requirements and small interfering RNA structure in the RNA interference pathway. Cell, 2001. 107(3): p. 309-21.

69. Elbashir, S.M., et al., Duplexes of 21-nucleotide RNAs mediate RNA interference in cultured mammalian cells. Nature, 2001. 411(6836): p. 494-8.

70. Oliveira, D.M. and M.A. Goodell, Transient RNA interference in hematopoietic progenitors with functional consequences. Genesis, 2003. 36(4): p. 203-8.

71. Brummelkamp, T.R., R. Bernards, and R. Agami, A system for stable expression of short interfering RNAs in mammalian cells. Science, 2002. 296(5567): p. 550-3.

72. Miyagishi, M. and K. Taira, U6 promoter-driven siRNAs with four uridine 3' overhangs efficiently suppress targeted gene expression in mammalian cells. Nat Biotechnol, 2002. 20(5): p. 497-500.

73. Paddison, P.J., et al., Short hairpin RNAs (shRNAs) induce sequence-specific silencing in mammalian cells. Genes Dev, 2002. 16(8): p. 948-58.

74. Tiscornia, G., O. Singer, and I.M. Verma, Design and cloning of lentiviral vectors expressing small interfering RNAs. Nat Protoc, 2006. 1(1): p. 234-40.

75. Tiscornia, G., O. Singer, and I. Verma, Development of lentiviral vectors expressing siRNA in Gene Transfer - Delivery and expression of DNA and RNA. Cold Spring Harbor Laboratory Press, 2007: p. 23-34.

76. Zufferey, R., et al., Woodchuck hepatitis virus posttranscriptional regulatory element enhances expression of transgenes delivered by retroviral vectors. J Virol, 1999. 73(4): p. 2886-92.

77. Zennou, V., et al., HIV-1 genome nuclear import is mediated by a central DNA flap. Cell, 2000. 101(2): p. 173-85.

78. Feng, M., et al., Activation of epidermal growth factor receptor mediates reperfusion arrhythmias in anaesthetized rats. Cardiovasc Res, 2012. 93(1): p. 60-8.

79. Barth, A.S., et al., Lentiviral vectors bearing the cardiac promoter of the Na+-Ca2+ exchanger report cardiogenic differentiation in stem cells. Mol Ther, 2008. 16(5): p. 957-64.

80. Jordan, M., Transfection of adherent and suspended cells by calcium phosphate. Methods, 2004. 33(2): p. 136-143.

81. Bailly, M., et al., Epidermal Growth Factor Receptor Distribution during

Chemotactic Responses. Molecular Biology of the Cell, 2000. 11: p. 3873-3883.

82. Diaz, R.G., et al., Myocardial Mineralocorticoid Receptor Activation by Stretching and Its Functional Consequences. Hypertension, 2013. 63(1): p. 112-118.

83. Nolly, M.B., et al., Cardiac hypertrophy reduction in SHR by specific silencing of myocardial $\mathrm{Na}(+) / \mathrm{H}(+)$ exchanger. J Appl Physiol (1985), 2015. 118(9): p. 1154-60.

84. Sahn, D.J., et al., Recommendations regarding quantitation in M-mode echocardiography: results of a survey of echocardiographic measurements. Circulation, 1978. 58(6): p. 107283.

85. Bunag, R.D., Validation in awake rats of a tail-cuff method for measuring systolic pressure. J Appl Physiol, 1973. 34(2): p. 279-82.

86. Portiansky, E.L., et al., Collagenous and elastic system fibres in the aorta of cattle poisoned by Solanum glaucophyllum. Vet Rec, 2002. 150(2): p. 42-5.

87. Perez, N.G., M.C. de Hurtado, and H.E. Cingolani, Reverse mode of the Na+-Ca2+ exchange after myocardial stretch: underlying mechanism of the slow force response. Circ Res, 2001. 88(4): p. 376-82.

88. Camilion de Hurtado, M.C., et al., Upregulation of myocardial $\mathrm{Na}+/ \mathrm{H}+$ exchanger induced by chronic treatment with a selective inhibitor. J Mol Cell Cardiol, 2002. 34(11): p. 1539-47.

89. Caldiz, C.I., et al., Mitochondrial reactive oxygen species activate the slow force response to stretch in feline myocardium. J Physiol, 2007. 584(Pt 3): p. 895-905.

90. Bradford, M.M., A rapid and sensitive method for the quantitation of microgram quantities of protein utilizing the principle of protein-dye binding. Anal Biochem, 1976. 72: p. 248-54. 
91. Villa-Abrille, M.C., et al., The Anrep effect requires transactivation of the epidermal growth factor receptor. The Journal of Physiology, 2010. 588(9): p. 1579-1590.

92. Cingolani, H.E., et al., Stretch-induced alkalinization of feline papillary muscle: an autocrine-paracrine system. Circ Res, 1998. 83(8): p. 775-80.

93. Perez, N.G., et al., A low dose of angiotensin II increases inotropism through activation of reverse $\mathrm{Na}(+) / C a(2+)$ exchange by endothelin release. Cardiovasc Res, 2003. 60(3): p. 58997.

94. Byrne, J.A., et al., Contrasting roles of NADPH oxidase isoforms in pressure-overload versus angiotensin II-induced cardiac hypertrophy. Circ Res, 2003. 93(9): p. 802-5.

95. Manjunath, N., et al., Lentiviral delivery of short hairpin RNAs. Adv Drug Deliv Rev, 2009. 61(9): p. 732-45.

96. Grimm, D., et al., Fatality in mice due to oversaturation of cellular microRNA/short hairpin RNA pathways. Nature, 2006. 441(7092): p. 537-41.

97. Mao, Y., et al., Lentiviral Vectors Mediate Long-Term and High Efficiency Transgene Expression in HEK 293 T cells. Int J Med Sci, 2015. 12(5): p. 407-15.

98. Nasri, M., A. Karimi, and M. Allahbakhshian Farsani, Production, purification and titration of a lentivirus-based vector for gene delivery purposes. Cytotechnology, 2014. 66(6): p. 1031-8.

99. Okamoto, K. and K. Aoki, Development of a strain of spontaneously hypertensive rats. Jpn Circ J, 1963. 27: p. 282-93.

100. Trippodo, N.C. and E.D. Frohlich, Similarities of genetic (spontaneous) hypertension. Man and rat. Circ Res, 1981. 48(3): p. 309-19.

101. Dang, A., et al., The role of the renin-angiotensin and cardiac sympathetic nervous systems in the development of hypertension and left ventricular hypertrophy in spontaneously hypertensive rats. Hypertens Res, 1999. 22(3): p. 217-21.

102. Dell'Italia, L.J., et al., Compartmentalization of angiotensin II generation in the dog heart. Evidence for independent mechanisms in intravascular and interstitial spaces. J Clin Invest, 1997. 100(2): p. 253-8.

103. Silva, S.D., Jr., et al., Temporal changes in cardiac oxidative stress, inflammation and remodeling induced by exercise in hypertension: Role for local angiotensin II reduction. PLoS One, 2017. 12(12): p. e0189535.

104. Alvarez, B.V., et al., Effects of antihypertensive therapy on cardiac sodium/hydrogen ion exchanger activity and hypertrophy in spontaneously hypertensive rats. Can J Cardiol, 2002. 18(6): p. 667-72.

105. Oddie, C.J., R.J. Dilley, and A. Bobik, Long-term angiotensin II antagonism in spontaneously hypertensive rats: effects on blood pressure and cardiovascular amplifiers. Clin Exp Pharmacol Physiol, 1992. 19(5): p. 392-5.

106. Mizuno, K., et al., Effects of losartan, a nonpeptide angiotensin II receptor antagonist, on cardiac hypertrophy and the tissue angiotensin II content in spontaneously hypertensive rats. Life Sci, 1992. 51(5): p. 367-74.

107. Ennis, I.L., et al., Enalapril induces regression of cardiac hypertrophy and normalization of pHi regulatory mechanisms. Hypertension, 1998. 31(4): p. 961-7.

108. Takai, S., et al., Significant target organs for hypertension and cardiac hypertrophy by angiotensin-converting enzyme inhibitors. Hypertens Res, 2004. 27(3): p. 213-9.

109. Kim, J., et al., Epidermal growth factor induces vasoconstriction through the phosphatidylinositol 3-kinase-mediated mitogen-activated protein kinase pathway in hypertensive rats. J Pharmacol Sci, 2006. 101(2): p. 135-43.

110. Camilion de Hurtado, M.C., et al., Regression of cardiomyocyte hypertrophy in SHR following chronic inhibition of the $\mathrm{Na}(+) / \mathrm{H}(+)$ exchanger. Cardiovasc Res, 2002. 53(4): p. 862-8.

111. Perez, N.G., et al., pHi regulation in myocardium of the spontaneously hypertensive rat. Compensated enhanced activity of the $\mathrm{Na}(+)-H+$ exchanger. Circ Res, 1995. 77(6): p. 1192- 
200.

112. Baartscheer, A., et al., Increased $\mathrm{Na}+\mathrm{H}+$-exchange activity is the cause of increased $[\mathrm{Na}+] \mathrm{i}$ and underlies disturbed calcium handling in the rabbit pressure and volume overload heart failure model. Cardiovasc Res, 2003. 57(4): p. 1015-24.

113. Nakamura, T.Y., et al., Activation of $\mathrm{Na}+/ \mathrm{H}+$ exchanger 1 is sufficient to generate Ca2+ signals that induce cardiac hypertrophy and heart failure. Circ Res, 2008. 103(8): p. 891-9.

114. Avkiran, M. and M.S. Marber, $\mathrm{Na}(+) / H(+)$ exchange inhibitors for cardioprotective therapy: progress, problems and prospects. J Am Coll Cardiol, 2002. 39(5): p. 747-53.

115. Engelhardt, S., et al., Inhibition of $\mathrm{Na}(+)-H(+)$ exchange prevents hypertrophy, fibrosis, and heart failure in beta(1)-adrenergic receptor transgenic mice. Circ Res, 2002. 90(7): p. 8149.

116. Takimoto, E. and D.A. Kass, Role of oxidative stress in cardiac hypertrophy and remodeling. Hypertension, 2007. 49(2): p. 241-8.

117. McMurray, J., et al., Evidence of oxidative stress in chronic heart failure in humans. Eur Heart J, 1993. 14(11): p. 1493-8.

118. Keith, M., et al., Increased oxidative stress in patients with congestive heart failure. J Am Coll Cardiol, 1998. 31(6): p. 1352-6.

119. Hare, J.M. and J.S. Stamler, NO/redox disequilibrium in the failing heart and cardiovascular system. J Clin Invest, 2005. 115(3): p. 509-17.

120. Ago, T., et al., Upregulation of Nox4 by hypertrophic stimuli promotes apoptosis and mitochondrial dysfunction in cardiac myocytes. Circ Res, 2010. 106(7): p. 1253-64.

121. von Anrep, G., On the part played by the suprarenals in the normal vascular reactions of the body. J Physiol, 1912. 45(5): p. 307-17.

122. Cingolani, H.E., et al., The Anrep effect: 100 years later. Am J Physiol Heart Circ Physiol, 2013. 304(2): p. H175-82.

123. Higashiyama, S., et al., A heparin-binding growth factor secreted by macrophage-like cells that is related to EGF. Science, 1991. 251(4996): p. 936-9.

124. Elenius, K., et al., Activation of HER4 by heparin-binding EGF-like growth factor stimulates chemotaxis but not proliferation. EMBO J, 1997. 16(6): p. 1268-78.

125. Iwamoto, R., et al., Heparin-binding EGF-like growth factor and ErbB signaling is essential for heart function. Proceedings of the National Academy of Sciences, 2003. 100(6): p. 32213226.

126. Gassmann, M., et al., Aberrant neural and cardiac development in mice lacking the ErbB4 neuregulin receptor. Nature, 1995. 378(6555): p. 390-4.

127. Garcia-Rivello, H., et al., Dilated cardiomyopathy in Erb-b4-deficient ventricular muscle. Am J Physiol Heart Circ Physiol, 2005. 289(3): p. H1153-60.

128. Perez, N.G., et al., Silencing of NHE-1 blunts the slow force response to myocardial stretch. J Appl Physiol (1985), 2011. 111(3): p. 874-80.

129. Levitzki, A. and A. Gazit, Tyrosine kinase inhibition: an approach to drug development. Science, 1995. 267(5205): p. 1782-8.

130. Thomas, W.G., et al., Adenoviral-directed expression of the type 1A angiotensin receptor promotes cardiomyocyte hypertrophy via transactivation of the epidermal growth factor receptor. Circ Res, 2002. 90(2): p. 135-42.

131. Santra, M., et al., Thymosin beta 4 up-regulates miR-200a expression and induces differentiation and survival of rat brain progenitor cells. J Neurochem, 2016. 136(1): p. 11832.

132. Carrasco-Garcia, E., et al., Small tyrosine kinase inhibitors interrupt EGFR signaling by interacting with erbB3 and erbB4 in glioblastoma cell lines. Exp Cell Res, 2011. 317(10): p. 1476-89.

133. Icli, B., et al., ErbB4 localization to cardiac myocyte nuclei, and its role in myocyte DNA damage response. Biochem Biophys Res Commun, 2012. 418(1): p. 116-21.

134. Chan, H.W., et al., Effect of dominant-negative epidermal growth factor receptors on 
cardiomyocyte hypertrophy. J Recept Signal Transduct Res, 2006. 26(5-6): p. 659-77.

135. Kokubo, M., et al., Noninvasive evaluation of the time course of change in cardiac function in spontaneously hypertensive rats by echocardiography. Hypertens Res, 2005. 28(7): p. 601-9.

136. Aiello, E.A., et al., Myocardial hypertrophy of normotensive Wistar-Kyoto rats. Am J Physiol Heart Circ Physiol, 2004. 286(4): p. H1229-35.

137. Schreier, B., et al., Loss of epidermal growth factor receptor in vascular smooth muscle cells and cardiomyocytes causes arterial hypotension and cardiac hypertrophy. Hypertension, 2013. 61(2): p. 333-40.

138. Vargas, L.A., et al., Inhibition of carbonic anhydrase prevents the $\mathrm{Na}(+) / \mathrm{H}(+)$ exchanger 1 dependent slow force response to rat myocardial stretch. Am J Physiol Heart Circ Physiol, 2013. 305(2): p. H228-37.

139. Alvarez, B.V., et al., Slc26a6: a cardiac chloride-hydroxyl exchanger and predominant chloride-bicarbonate exchanger of the mouse heart. J Physiol, 2004. 561(Pt 3): p. 721-34.

140. Iwabu, A., et al., Epidermal growth factor induces fibroblast contractility and motility via a protein kinase C delta-dependent pathway. J Biol Chem, 2004. 279(15): p. 14551-60.

141. Pimentel, D.R., et al., Strain-stimulated hypertrophy in cardiac myocytes is mediated by reactive oxygen species-dependent Ras S-glutathiolation. J Mol Cell Cardiol, 2006. 41(4): p. 613-22.

142. Sugden, P.H. and A. Clerk, Oxidative stress and growth-regulating intracellular signaling pathways in cardiac myocytes. Antioxid Redox Signal, 2006. 8(11-12): p. 2111-24.

143. Cingolani, H.E., et al., The positive inotropic effect of angiotensin II: role of endothelin-1 and reactive oxygen species. Hypertension, 2006. 47(4): p. 727-34.

144. Shah, B.H., et al., Roles of Src and epidermal growth factor receptor transactivation in transient and sustained ERK1/2 responses to gonadotropin-releasing hormone receptor activation. J Biol Chem, 2003. 278(21): p. 19118-26.

145. Zhang, Y., et al., Induction of EGFR-dependent and EGFR-independent signaling pathways by ultraviolet A irradiation. DNA Cell Biol, 2001. 20(12): p. 769-79.

146. De Giusti, V.C., et al., Aldosterone Stimulates the Cardiac Na+/H+ Exchanger via Transactivation of the Epidermal Growth Factor Receptor. Hypertension, 2011. 58(5): p. 912-919.

147. Correa, M.V., et al., Endogenous endothelin 1 mediates angiotensin II-induced hypertrophy in electrically paced cardiac myocytes through EGFR transactivation, reactive oxygen species and NHE-1. Pflugers Arch, 2014. 466(9): p. 1819-30.

148. Fujino, T., et al., Enhanced expression of heparin-binding EGF-like growth factor and its receptor in hypertrophied left ventricle of spontaneously hypertensive rats. Cardiovasc Res, 1998. 38(2): p. 365-74.

149. Ai, W., et al., Silibinin attenuates cardiac hypertrophy and fibrosis through blocking EGFRdependent signaling. Journal of Cellular Biochemistry, 2010. 110(5): p. 1111-1122.

150. Zhou, B., et al., Silibinin protects against isoproterenol-induced rat cardiac myocyte injury through mitochondrial pathway after up-regulation of SIRT1. J Pharmacol Sci, 2006. 102(4): p. 387-95.

151. Imai-Sumida, M., et al., Silibinin suppresses bladder cancer through down-regulation of actin cytoskeleton and PI3K/Akt signaling pathways. Oncotarget, 2017. 8(54): p. 9203292042.

152. Cingolani, H.E., et al., Regression of hypertensive myocardial fibrosis by $\mathrm{Na}(+) / \mathrm{H}(+)$ exchange inhibition. Hypertension, 2003. 41(2): p. 373-7.

153. Schreier, B., et al., Loss of Epidermal Growth Factor Receptor in Vascular Smooth Muscle Cells and Cardiomyocytes Causes Arterial Hypotension and Cardiac Hypertrophy. Hypertension, 2012. 61(2): p. 333-340. 


\section{ANEXO - Primers, buffers, soluciones y anticuerpos}

\section{Primers}

- EGFR sense: 5'-CCACTCGGATCCcGCATAGGCATTGGTGAATTtatgtgcttA ATTCACCAATGCCTATGCgTTTTTTCCAAGAATTCTTAATTAA GGTACC- $3^{\prime}$

- EGFR antisense: 5'-GGTACCTTAATTAAGAATTCTTGGAAAAAAcGCATA GGCATTGGTGAATTaagcacataAATTCACCAATGCCTATGCgGGATC CGAGTGG - $3^{\prime}$

- SCR sense: 5' - CCACTCGGATCCCATGGCATTGCGATAAGTTGtatgtgcttCA ACTTATCGCAATGCCATgTTTTTTCCAAGAATTCTTAATTA AGGTACC - 3 '

- SCR antisense: 5' - GGTACCTTAATTAAGAATTCTTGGAAAAAAcATGGC ATTGCGATAAGTTGaagcacataCAACTTATCGCAATGCCATgGGATCCGAGTGG $3^{\prime}$

- Primer H1F2: $\quad$ 5'- TCGCTATGTGTTCTGGgaAA -3'

- Primer M13: $\quad 5^{\prime}$-GTAAAACGACGGCCAGT -3'

- Primer T7: 5' $\quad$ - TAATACGACTCACTATAGGG -3'

\section{Buffers y soluciones}

- TAE (Tris-Acetato-EDTA): Tris $40 \mathrm{mM}$, ácido acético $20 \mathrm{mM}$, EDTA $1 \mathrm{mM}, \mathrm{pH}=8$.

- SOC (Super Optimal broth with Catabolite repression): bactotriptona 20\%, extracto de levadura 0,5\%, $\mathrm{NaCl} 10 \mathrm{mM}, \mathrm{KCl} 2,5 \mathrm{mM}, \mathrm{MgCl}_{2} 10 \mathrm{mM}$ y glucosa $20 \mathrm{mM}$.

- LB (Lysogeny Broth): peptona 1\%, extracto de levadura 0,5\%, $\mathrm{NaCl} 1 \%$.

- Solución 1 - Maxiprep: glucosa 50 mM, Tris 25 mM y EDTA 10 mM, pH 8.

- Solución 2 - Maxiprep: NaOH 2 M y SDS 1\%.

- Solución 3 - Maxiprep: acetato de potasio 3 M, ácido acético glacial hasta pH 5. 
- Solución Ringer: $\mathrm{NaCl}$ 128,3 mM, KCl 4,5 mM, $\mathrm{CaCl}_{2}$ 1,35 mM, NaHCO 3 20,23 mM, $\mathrm{MgSO}_{4}$ 1,05 mM, glucosa 11,0 mM. Equilibrada con 5\% $\mathrm{CO}_{2}-95 \% \mathrm{O}_{2}(\mathrm{pH} 7,40)$.

- Buffer HEPES: $\mathrm{NaCl}$ 146,2 mM, KCl 4,5 mM, CaCl 2 1,35 mM, $\mathrm{MgSO}_{4}$ 1,05 mM, glucosa 11,0 mM, HEPES 10,0 mM, llevado a $\mathrm{pH} 7,4$ con $\mathrm{NaOH}$ y equilibrado con $100 \% \mathrm{O}_{2}$.

- Buffer de lucigenina: $\mathrm{NaCl} 118,3 \mathrm{mM}, \mathrm{KCl} 4,7 \mathrm{mM}, \mathrm{CaCl}_{2}$ 1,8 mM, $\mathrm{MgSO}_{4}$ 1,2 mM, $\mathrm{K}_{2} \mathrm{HPO}_{4}$ 1,0 mM, NaHCO 25 mM, glucosa 11 mM, HEPES 20 mM. pH 7,4 luego de 1.5 hs de gaseo con $95 \% \mathrm{O}_{2}-5 \% \mathrm{CO}_{2}$ a $37^{\circ} \mathrm{C}$. Se adicionó $5 \mu \mathrm{M}$ de lucigenina.

- Buffer de corrida SDS-PAGE: glicerol 20\%, 2-mercaptoetanol 2\%, SDS 4\%, azul de bromofenol 1\%, Tris $150 \mathrm{mM}$, pH 6,8.

- Buffer de transferencia: metanol 20\%, Tris 25 mM y glicina $192 \mathrm{mM}$.

- Solución de bloqueo: T-TBS (Tween-20 0,1\%, NaCl 137 mM, Tris 20 mM, pH 7,5), conteniendo $10 \%$ de leche en polvo descremada.

\section{Anticuerpos primarios}

- Anti-EGFR (sc-03), 1:1.000 preparado 1\% albúmina en T-TBS.

- Anti-ErbB2 (sc-284), 1:1.000 preparado 1\% albúmina en T-TBS.

- Anti-ErbB4 (sc-283), 1:1.000 preparado 1\% albúmina en T-TBS.

- Anti-gp91-phox (sc-130543), preparado 1:2.000 5\% leche en T-TBS.

- Anti-P-p90 (sc), 1:1.000 preparado 1\% albúmina en T-TBS.

- Anti-P-ERK1/2 (sc), 1:1.000 preparado 1\% albúmina en T-TBS.

- Anti- gliceraldehído-3-fosfato deshidrogenasa (GAPDH) (sc-47724), 1:1.000 preparado $1 \%$ leche en T-TBS.

- Anti-ßactina (sc-130656), 1:1.000 preparado 1\% albúmina en T-TBS.

\section{Anticuerpos secundarios}

- Anti-conejo, 1:10.000 preparado 5\% albúmina en T-TBS.

- Anti-ratón, 1:10.000 preparado 5\% albúmina en T-TBS.

- Anti-cabra, 1:5.000 preparado 5\% albúmina en T-TBS. 